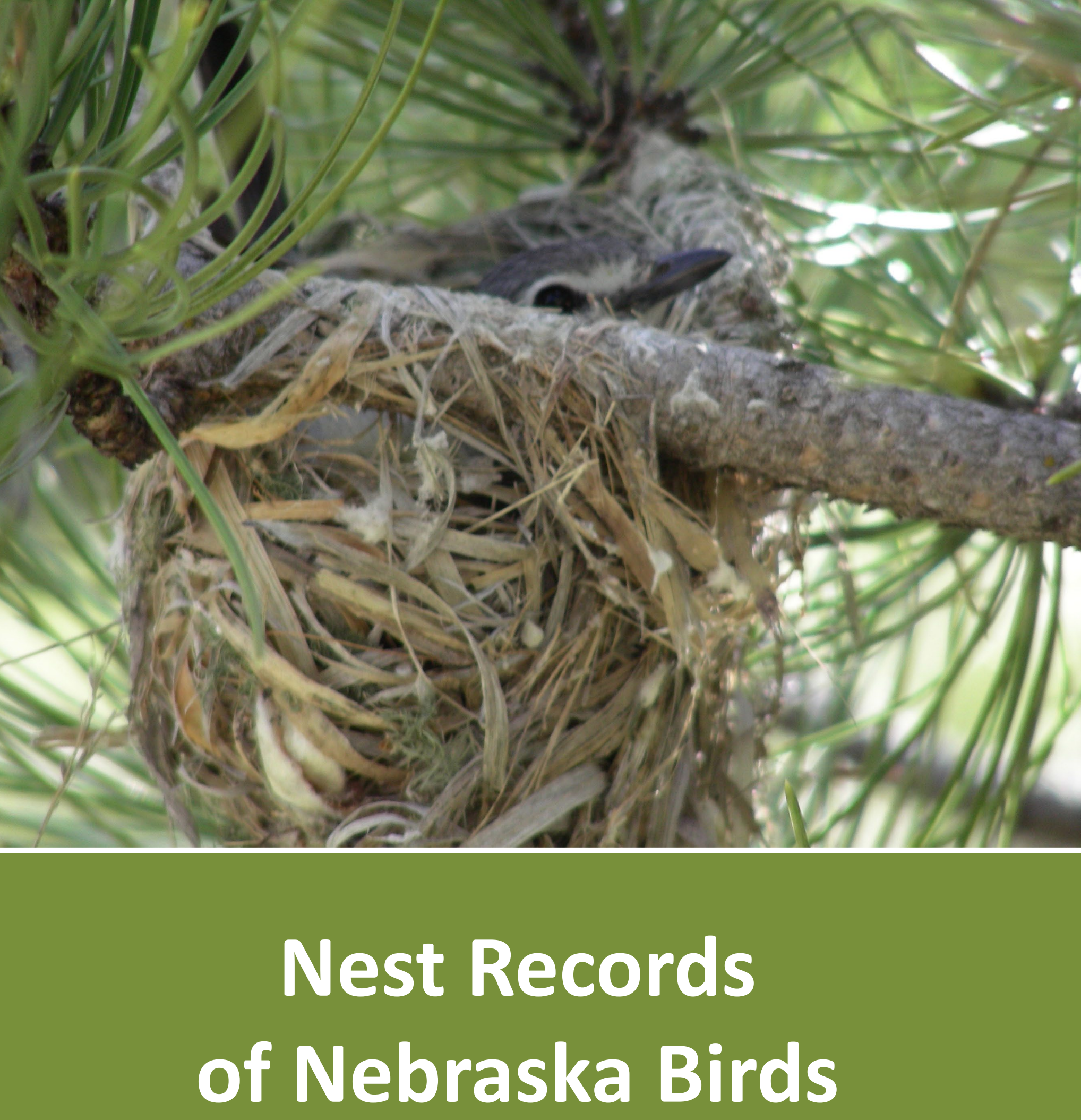

Wayne J. Mollhoff

Nebraska Ornithologists' Union Occasional Paper Number 9 


\section{Nest Records of Nebraska Birds}

Nebraska Ornithologists' Union Occasional Paper Number 9

Wayne J. Mollhoff

Lincoln, Nebraska 2022 
Copyright @ 2022 Wayne J. Mollhoff

ISBN: 978-1-60962-235-0 paperback

ISBN: 978-1-60962-236-7 ebook

doi:10.32873/unl.dc.zea.1318

Zea Books are published by the

University of Nebraska-Lincoln Libraries.

Electronic (pdf) edition available online at

https://digitalcommons.unl.edu/zeabook/

Print edition available from Lulu.com at

http://www.lulu.com/spotlight/unllib

UNL does not discriminate based upon any protected status.

Please go to http://www.unl.edu/equity/notice-nondiscrimination

\section{Nebraska}




\section{Table of contents}

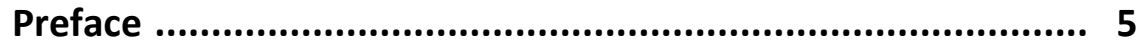

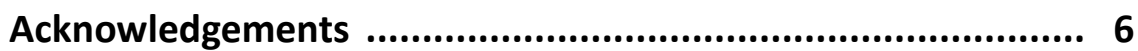

Introduction ......................................................................... 8

Contributors ................................................................... 11

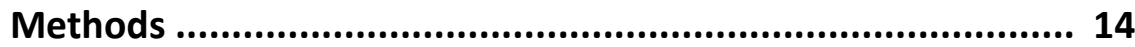

Species accounts .................................................................. 15

References cited ................................................................. 95

Appendices

A. Abbreviations used .............................................. 108

B. Gazeteer ............................................................... 110 


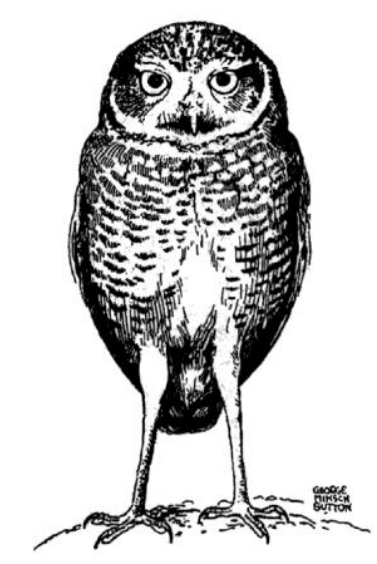

The Nebraska Ornithologists' Union

is dedicated to the study, appreciation and protection of birds.

Website: https://noubirds.org/

Publication: The Nebraska Bird Review

https://digitalcommons.unl.edu/nebbirdrev/ 


\section{PREFACE}

When I began this project, I envisioned little more than summarizing the records I had accumulated in the previous forty-five years. They included my own observations, reports by others collected for the Cornell Nest Record Card Program, and those collected during the two Nebraska Breeding Bird Atlas Projects (NBBAP I \& II). The cutoff date for records included is 2020. There have been a number of important sightings since that time that are not included due unavoidable health issues on my part.

A box of recently uncovered century-old, original nest cards from professional and amateur egg collectors added a wealth of detailed information. Reviewing them revealed the speed of the massive landscape change wrought by the homesteaders in only a decade or two.

Those changes have not stopped and make it incumbent on current observers to record in detail not only the birds themselves, but also the habitats they use.

My search also found interesting tidbits such as: I. S. Trostler's nest card of a Grasshopper Sparrow nest and eggs collected "...on May 281899 in the pasture on the west side of 48th and Farnum Streets in Omaha". And finding Lawrence Bruner's nest 'card' for a Sennett's Nighthawk nest, written on a wooden slat from a food basket, while he was afield collecting.

The research not only revealed species nesting where they no longer breed; but also some species that were apparently not present a century ago, in locations where they are now common. An example: despite several summers of intensive collecting in the Pine Ridge, they found no breeding Red-breasted or Pygmy Nuthatches, species common there now.

Although my search seemed tedious at times, the fascinating trove that I found made it well worthwhile. May your perusal of this report also prove of interest.

Enjoy. 


\section{ACKNOWLEDGEMENTS}

In addition to my own observations, many records were gleaned from state and federal agencies, and non-governmental organizations, including: the Valentine, Crescent Lake, and North Platte National Wildlife Refuges, the Nebraska Natural Heritage Program, Tern and Plover Conservation Partnership, Nebraska Prairie Partners, Bird Conservancy of the Rockies, Whooping Crane Trust, Army Corps of Engineers, Central Nebraska Public Power and Irrigation District, publications of the Nebraska Ornithologists' Union, and the Nebraska Ornithologists' Union archives. Aside from the archived records within these organizations, several individuals made available their personal notes and daily work logs as well.

Special thanks go to Thomas Labedz, Collections Manager of the Vertebrates Collection at the University of Nebraska State Museum, where I was given access to the egg collection card file. He also noted that many museums had made their collections available for on-line access through VertNet.org, and I was able to search the collections of an additional 21 museums across the US and Canada for Nebraska specimens. The data files at the UNSM and other museums sometimes also included the original field notes and even individual nest cards of the egg collectors. These proved invaluable since the egg collectors routinely recorded details of information about habitat, nest placement, nest structure, clutch size, and stage of incubation, which, by itself, could tell whether a smaller than usual number of eggs was incomplete rather than a small completed clutch.

Special thanks are also due to Mary Ellen Ducey and staff at the UNL Love Library for making available assorted archival material. It now holds the bulk of the NOU archives as well as the papers and correspondence of early university professors. Thanks also to Teresa Kreutzer-Hodson for granting access to collection records at the Hastings Museum, as well as to the volunteer staff at the Sellors-Barton Museum in Ainsworth, NE.

Invaluable assistance was rendered by Jim Lowe, of the Laboratory of Ornithology at Cornell University Nest Record Card Program, in scouring for Nebraska records among the hundreds of thousands of file cards submitted to that program.

Online records were gleaned from the following museums: California Academy of Natural Sciences (San Francisco, CA), Carnegie Museum of Natural History (Pittsburgh, PA), Denver Museum of Nature and Science (Denver, CO), Field Museum of Natural History (Chicago, IL), Florida Museum of Natural History (Gainesville, FL), Humboldt State University (Arcata, CA), Michigan State University Museum (East Lansing, MI), Harvard Museum of Comparative Zoology (Cambridge, MA), Smithsonian National Museum of Natural History (Washington, DC), New York State Museum (Albany, NY), Yale University Peabody Museum (New Haven, CT), Royal Ontario Museum (Toronto, ON), Santa Barbara Museum of Natural History (Santa Barbara, CA), University of California Museum of Vertebrate Zoology (Berkeley, CA), University of Kansas Biodiversity Institute (Lawrence, KS), University of Michigan Museum of Zoology (Ann Arbor, MI), University of Oklahoma Noble Museum of Natural History (Norman, OK), University of Washington Burke Museum (Seattle, WA), University of Washington Connor Museum (Pullman, WA), University of Washington Slater Museum of Natural History (Tacoma, WA), and Western Foundation of Vertebrate Zoology (Camarillo, CA). 
My profound gratitude is expressed especially to Janis Paseka and others of the editorial staff of the Nebraska Ornithologists' Union and to the reviewers for their assistance and long-suffering patience in seeing the project through to publication.

Finally, any mistakes, errors or omissions are my own. 


\section{INTRODUCTION}

Nebraska is located near the center of temperate North America, roughly bounded by $40^{\circ}-43^{\circ}$ north latitude and $96^{\circ}-104^{\circ}$ west longitude and has an area of approximately 77,500 square miles $(200,600$ square kilometers). Its eastern border marks the edge of the Great Plains. Historically the state was dominated by a variety of grasslands maintained by periodic fires that largely limited woodlands to major river valleys in the east, and to rocky ridges and canyons in the Panhandle (Wishart 2004). Following the Civil War, the dispossession of the Native American tribes and slaughter of the bison, within a generation European settlers had plowed under much of the tallgrass prairie, converting it to farmland. The Sandhills proved unsuitable to traditional agriculture and was instead fenced for grazing cattle which also affected the habitat.

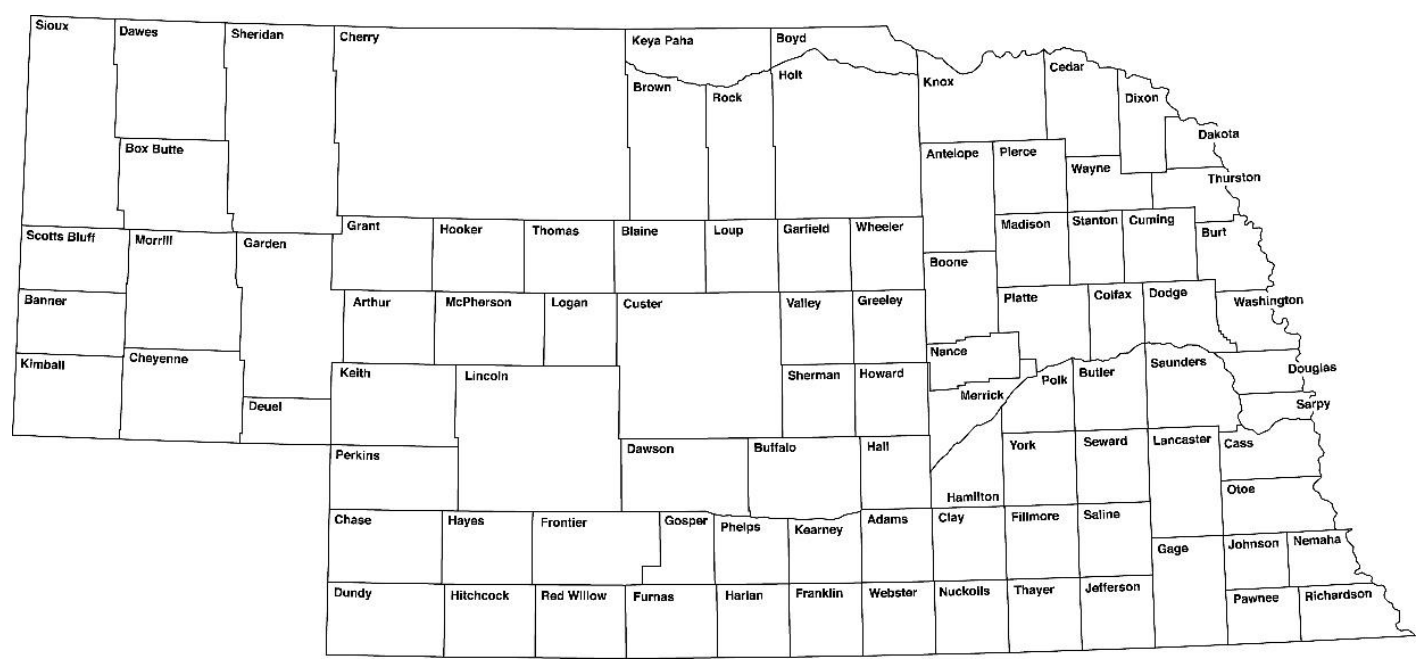

Nebraska Counties. Map courtesy of University of Nebraska State Museum.

The beginnings of scientific study of the birds of Nebraska date to the exploratory Army expedition of Lewis and Clark, which was sent to explore and map the Louisiana Purchase in 1803. Subsequent expeditions throughout the century charted the rivers, established overland trails and railroad routes. They also included naturalists and scientists to record and collect what they found. A more complete story of this period was included in The Birds of Nebraska (Sharpe et al. 2001).

Modern bird study in the United States got underway with the formation of the American Ornithologists' Union (AOU) in 1883, a number of whose founders were army surgeons or naturalists on the early expeditions (Davis and Butler 2016). Also instrumental in the foundation of ornithology as a science were museums, including the National Museum of Natural History (Smithsonian Institution), Washington D.C., American Museum of Natural History, New York City, the Academy of Natural Sciences, Philadelphia, the Peabody Museum at Yale University, and museums at other eastern universities.

Soon after it was founded, the AOU set up a committee to establish and publish a single nomenclature and checklist to unify the profusion of bird names then in use. Their work 
resulted in The Code of Nomenclature and Check-list of North American Birds (American Ornithologists' Union 1886).

Formal bird study in Nebraska began with the establishment of the state university and college system following statehood in 1867. The Nebraska Ornithologists' Union (NOU) was founded in 1899, with a core of University of Nebraska professors, as well as interested students and amateurs (Sharpe et al. 2001). Since its inception, the NOU has published observations and studies in its Proceedings, Letters of Information, the Wilson Bulletin, the Nebraska Bird Review, Occasional Papers, and periodic Check-lists. Reports of breeding activity are scattered throughout these publications. By the mid-1950s, nesting summaries were published more or less regularly (Seabury 1956), and with the inception of the North American Nest Record Card Program by the Cornell Laboratory of Ornithology in the 1960s, an annual report was published (Sharpe 1967). Unfortunately for this project, many of those annual reports did not give the detail necessary to make them of full use. Often only the county was listed as a location, and the clutch size was rarely given. Unfortunately also, in that time before ready access to copiers, copies of the cards that held the details were not retained when the cards were sent to Cornell. In preparation for the second breeding bird atlas project, I spent a week at Cornell University, copying all of the Nebraska cards I could find, and added them to my own nest card file which I had started in 1971. Prior to going to Cornell, I made a list of some especially unusual or rare reports I found in the Bird Review, but found that some could not be located.

Two breeding bird atlas projects have since been completed, NBBAP I (1984-1989) and NBBAP II (2006-2011), but the only breeding records that could be included in the publications were those collected in conjunction with each project (Mollhoff 2001a, 2016).

This publication is an attempt to provide a synopsis of the breeding information accumulated in the past two centuries. As with any compilation like this, other workers would likely come to different conclusions in choosing which records to accept and which to reject. I have tried to state the reasons for my decisions as clearly as possible. Most difficult to categorize are species which are not well documented. Hopefully by laying out the evidence I could find, others will be prompted to do more research, uncover definitive proof, and put more of our questionable reports to rest. Of necessity, this synopsis is incomplete, since there are undoubtedly publications, records, and museum specimens which I have been unable to access, and others of which I am unaware.

\section{EGG COLLECTIONS}

During the heyday of egg collecting, it was common for budding naturalists to collect eggs and nests as a way to begin their study of nature. Several magazines were published to offer guidance, a place to publish their findings, and connect with like-minded students of the outdoors. Although now often dismissed as mere collecting for the sake of amassing a collection, in the late 19th century oologists were hopeful of using that method to help answer questions of embryology and taxonomy. At that time, ornithology itself was still on its way to becoming a science. In Instructions for Collecting, Preparing, and Preserving Birds' Eggs and Nests, Bendire (1891) admonished the would-be collector that unless he intended "...an especial study....and has a higher aim than the mere desire to...accumulate a large number....he had better not begin at all." In deciphering the annotations on the old collectors' notes in the 
museums, I found Bendire's "Instructions," along with those of Coues $(1874,1903)$, very helpful. In a final bit of irony, while the oologists were unable to use eggs to settle taxonomic questions, it was egg-white proteins that Sibley and others later used to refine avian classification (Sibley 1960, 1962).

It should be noted here that both state and federal permits are needed by anyone, and by every institution that possesses, collects, salvages, or otherwise handles birds eggs.

When non-scientific collecting was banned by the Migratory Bird Treaty between the US and Britain (on behalf of Canada) in 1916, followed by enforcing legislation enacted in 1918, egg collecting without a scientific permit was prohibited (Erhlich et al. 1988). Many of the eggs collected in Nebraska by some of the founding members of the Nebraska Ornithologists' Union eventually made their way into museum collections at the University of Nebraska, and to other museums across the US and Canada. In hindsight it is easy bemoan such hobby collecting, which at the time may have been somewhat like the life/state/county/yard lists of today. Yet without those eggs in the museums for reference, the puzzle of the catastrophic decline of Peregrine Falcon, Bald Eagle and Brown Pelican a half-century ago might not have been solved in time to save those species from extirpation or even extinction (White et al. 2002, Birkhead 2016). Even with the large numbers of eggs currently in collections, there remain many unanswered questions. A major problem with existing collections is that there is almost no current, on-going collecting that could be used to document current changes caused by pesticides or other chemicals. Random salvage of infertile eggs or hatched eggshells would be useful, but even that is made difficult because so few collectors or museum staff have the expertise and necessary tools to prepare them (Kiff 2005).

Recent studies in Europe have shown that onset of the breeding season is beginning earlier as the climate of northern Europe has warmed in the past several decades. To be able to demonstrate those changes however, one must have an extensive database of the species studied, with a large number of records collected annually, throughout the study period. Unfortunately none of those criteria has been met in our area. 


\section{CONTRIBUTORS}

Following is a list of 529 individuals who collected the records which provide the basis for this synopsis. The records range in date from 1811 to 2019. The contributors include founding members of the American Ornithologists' Union and the Nebraska Ornithologists' Union. It includes university professors, their students who went on to become internationally honored ornithologists, as well as amateurs whose names have not been previously seen in print. Research projects on species of concern sometimes listed individual names, while others listed only the project leader and did not always credit individual workers. All contributed valuable basic information to what we know today.

Jason Aleman-Zometa, Oscar Alexis, Edward Allen, Scott Allison, Frank Andelt, B. W. Anderson, Brie Anderson, C. L. Anderson, Frank Anderson, George Anderson, Johnny Anderson, Patti Anderson, R. J. Anderson, Clarence Andresen, Fred Andrus, Sam Antholz, Samuel Aughey.

P. S. Babcock, Laurel Badura, Edward Balbach, Mary Bamberger-Brown, R. M. Barnes, Roland Barth, Oona Bassett, Rev. John M. Bates, Karine Becker, Elliott Bedows, Bob Behrens, Harold Benckeser, Cpt. Charles Bendire, Esther V. Bennett, W. W. Bennett, J. Bergquist, J. Bingaman, Cyrus A Black, Sue Blackman, Loren "Bub" Blake, John C. W. Bliese, George Blinco, Myrtle Blinco, Lawrence Blus, Bart Bly, Jesse Bolli, B. F. Bolt, J. R. Bonwell, J. B. Boswell, Robert Brashears, A. M. Brausting, Tanya Bray, Kevin Brennan, Duane Bright, Norma Brockmoller, Didi Brogden, Doug Brogden, Ed M. Brogie, Mark A. Brogie, O. W. Bronson, A. M. Brooking, Ralph Brooks, Albert Brown, Charles R. Brown, George W. Brown, Linda R. Brown, Mary Bomberger Brown, Lawrence Bruner, F. Buckstaff, C. D. Bunker, Loron Bunney, Lawrence Burman, J. B. Burnett, David Busch, Scott Buss.

Agnes Callaway, Susie Callaway, John Carlini, D. E. Carlson, Kenneth Carnes, W. L. Carpenter, Melbourne A. Carriker, Donald W. Carter, Merritt Cary, Fitz H. Chapin, Dan Chase, Warren Chase, John L. Childs, Jennifer Chiu, Norman Chupp, Calvin L. Cink, Marcia Claesson, Mary K. Clausen, Nathan Click, F. B. Clinchard, F. A. Colby, George A. Coleman, Mrs. Carl N. Collister, J. R. Commers, Vera Coons, Kelly Corman, Rushton G. Cortelyou, M. A. Cox, J. C. Crawford, Jr., Kathleen Crawford-Rose, Bernie Culuk, Dan Culuk, N. J. Czaplewski.

Glen Dappen, Ralph W. Dawson, Garret Day, Mrs. George Day, Dudley DeGroot, Kathy

DeLara, G. D. Deyle, J. A. Dickenson, Frederick Dille, Kit Dimon, John J. Dinan, Stephen

Dinsmore, Lawrence Dokulil, Howard Doole, Jeff Drahota, Dean Drawbaugh, Phyllis Drawbaugh, James Ducey, Steve Duecker, Paul Dunbar, Mike Dwyer.

August Eigsti, W. E. Eigsti, Larry Einemann, David Elwonger, Richard Ernst, Raymond

Evans, H. R. Eschenburg, John Ewing.

J. K. Faeh, Carol Falk, Laurence Falk, Kent Fiala, Edson Fichter, Twile Fickel, Ruth Fleming, Rick Folchert, Bruce Ford, Deb Ford, Norman L. Ford, J. S. Foster, John Fredrickson, Marlin French, Mike Fritz, Michele Fuhrer-Hurt.

Ira N. Gabrielson, Angus Garey, Pamela A. Garrels, William C. Garthright, Doris B. Gates, Leroy M. Gates, Richard A. Gersib, Bob Gerten, Allisyn Gillet, Joseph Gillilan, Earl W. Glandon, William R. Glenn, Andi Glidden, Ed Gordon, N. E. Goss, Nathaniel H. Goss, Ruth Green, Ellis Greiner, Bob Grier, B. E. Griffith, Jonas Grundman, Richard Guarino, Joseph A. Gubanyi, Harvey L. Gunderson. 
Frederick W. Haecker, Tim Hajda, A. Hall, Carolyn Hall, Mrs. J. W. Hall, John W. Hall, Will Halleron, Tyler Hallman, Luke J. Hamilton, Carrie C. Hansen, Chris Hansen, Jason Hanser, B. H. Hanson, Robin Harding, Dr. A. Trevening Harris, Harry H. Harris, Daniel E. Hatch, Harry Heafer, Carr Heaney, Geraldine Heartwell, David W. Heidt, Lorene Heineman, Lola Held, David Hellbusch, Chris Helzer, Elsie Helzer, Henry W. Henshaw, Dr. C. W. Hepperlin, Gary L. Hergenrader, Ralph Herrington, Harlan B. Hess, Gene R. Hickman, Tyler Hicks, J. P. Hild, Fr. Thomas Hoffman, Glen Hoge, Charles E. Hoger, H. C. Holcomb, Dr. Larry C. Holcomb, Jane Holst, Eric Hopps, L. O. Horsky, R. D. Hoyt, Steve Huber, George E. Hudson, Helen Hughson, Joseph S. Hunter, Walter D. Hunter, Clarence W. Huntley, William F. Huser, Joseph M. Hyland.

H. Ihrig, R. H. Imler.

Clyde Johnson, Emma D. Johnson, G. E. Johnson, Jan A. Johnson, Dr. Norma G. Johnson, Richard L. Johnson, D. E. Jones, Stephen Jones, Joel G. Jorgensen.

Harold A. Kantrud, F. J. Keller, Alice M. Kenitz, K. K. Kennedy, Kelly Kerchmer, Courtney Kerns, L. G. Killion, L. K. Killion, Daniel H. Kim, Lanny Kizer, Clem Klaphake, Horace A. Kline, Page Klug, Joan Kohls, Dawn Konkoly, William T. Krummes, Erin Kucera.

Thomas E. Labedz, H. Lang, Aaron Larsen, Kathy Larson, Glenn LeDioyt, Dan Leger, Chuck Lesiak, Harrison Lewis, Mrs. Carl Lindeken, Mark Lindvall, Gary R. Lingle, Ross A. Lock, Lucy Logan, Dr. Stanley Longfellow, Guy Love, Jim Luchsinger, Charles S. Ludlow, Scott Luedtke, John Lueshen, Rufus Lyman, Blain Lyne.

Kim Madrigal, James M. Malkowski, Robert Mann, Rick Manning, Helen Martin, Marty Mathieson, Ann Mathisen, John Mathisen, Vera Maunder, Gordon Maurer, George Maxwell, Nates McClellean, H. Elliott McClure, Leonard McDaniel, Steve Mcllree, B. Meduna, H. Metzger, Clarence E. Mickel, Mrs. Archie Middleton, Carmela Miller, S. L. Minneman, C. A. Mitchell, Caleb Mitchell, Glen A. Mitchell, Randy Modlin, Levi L. Mohler, Wayne J. Mollhoff, Brian C. Moody, Douglas C. Moody, Scott M. Moody, Megan Moore, W. L. Moore, Rusty Moran, Lee E. Morris, Steve Morris, John Morrison, G. W. Morse, Margaret M. Morton, Dr. R. Allyn Moser, Michael Mossman, Jim Mountjoy, Ray V. Mullen, Roy B. Mullen, Jerry Mulliken, Don M. Mullison, Emily Munter, Heidi Murray, Ann A. Myers.

G. Nason, Leta M. Neeland, Melvin Nenneman, Marilyn Newcomb, Roger Newcomb, Mrs. W. H. Nielsen, Jim M. Nissen, Colleen Noecker.

Harry C. Oberholser, George Ohlein, John Ott, Mabel Ott, L. G. Otto, Robert Overing. Barbara "Babs" K. Padelford, Loren Padelford, Don Paseka, Erin Paseka, Janis Paseka, Deb Paulson, Raphael R. Payne, P. B. Peabody, Arthur S. Pearse, Mary B. Pendley, L. Iola Pennington, Eldon O. Percival, Ruth P. Percival, Don Perkuchin, Alfred E. Perry, Brian Peterson, Liven A. Peterson, Milford Pew, Doreen Pfost, L. J. Pickett, Gayle Pickwell, R. E. Pillmore, Thomas W. Polhemus, Janis Poppe, Leroy Poppe, Jessica Powder, Roger Powell, C. G. "Bud" Pritchard, Jerry Probst, A. Pyfer, J. S. Pyfer.

N. V. Radford, Lanny Randolph, Neal Ratzlaff, Sarah Rehme, Allen Reyer, Kelly Rezac, Rebecca Rhodes, Dr. Guy C. Rich, David Richert, Tiffany Rinaldi, Justin Rink, E. R. Ritchey, O. W. Ritchey, L. Robbins, Mark Robbins, H. Roberts, K. Robertson, Aileen Rodgers, Sievert A. Rohwer, Dorothy J. Rosche, Richard C. Rosche, David G. Rose, Travis Rusch.

George W. Sabine, Leslie R. Sabine, Lester R. Sabine, Bryan L. Sage, J. Henry Sather, H. P. Saugust, C. W. Schafer, William A. Schleicher, Rick Schmid, John Schmidt, Leonard Schmitt, Shari Schwartz, Marvin Schwilling, Mrs. George Seabury, Mr. \& Mrs. Lloyd Seabury, Charles W. 
Shafer, Ward M. Sharp, Robert Sharpe, Dr. Roger S. Sharpe, R. P. Sharples, Cameron Shelton, Glenn Sherman, Gail M. Shickley, Frank H. Shoemaker, Jacob Sigler, W. Ross Silcock, Leonard H. Sisson, Kent Skaggs, Ben Skipper, Lawrence Skow, D. Smith, William "Will" Smith, N. S. Snow, Glendel Snyder, Larry Snyder, Ruth R. Sorensen, H. Spink, David A. Stage, D. W. Stahlecker, Mrs. A. H. Staley, Becky Steidl, Steve Stephens, Dr. T. C. Stephens, Audrey Sterkel, Charles A. Stewart, J. Patrice Stewart, Joseph E. Stipsky, O. L. Stoltenberg, C. Stonerook, Jon Strong, Randy G.

Stutheit, Dr. George Suckley, John Sullivan, S. Sullivan, Susan Sullivan, George M. Sutton, Mrs. Kermit Swanson, Myron H. Swenk, Jim Swenson, Linda Swenson.

Martha Tacha, James Tate, Frances L. Taylor, H. R. Taylor, Dix Teachenor, Barb Tebbel, C. M. Thompson, Karen Timm, Romeo Tinajero, Jerry Toll, Dr. Diana F. Tomback, Fred Tout, Rebecca Tout, Wilson Tout, Add C. Townsend, Mary M. Tremaine, Mrs. George Trine, Isador S. Trostler, Joseph Trostler, Harold J. Turner, Curt Twedt.

F. M. Uhler, Zee Uridil, Moni Usasz.

Matthew Van Den Broeke, Elizabeth Van Sant, G. E. Verrill, Mr. \& Mrs. Glenn Viehmeyer, Eric Volden, Dale A. Von Steen.

Gerald "Jerry" Walker, Jake Walker, Thomas J. Walker, Dick Wallace (Omaha), Dick Wallace (O'Neill), Eddie Wallace, J. E. Wallace, Dr. Michael Wallace, D. S. Walsworth, Don Walters, John Wampole, Arlo Warner, F. M. Warren, Gordon Warrick, Harry E. Weakly, P. L. Weber, J. R. Weddel, Bernice Welch, Elmer West, Ralph West, Richard West, Ben Wheeler, Charles Acey White, W. T. White, Mr. \& Mrs. Harold Whitmus, William "Bill" Whitney, D. L. Widick, John E. Wilbrecht, Arthur Wiley, Jesse Williamson, Michael Willison, Gabriel Wilson, Suzanne Winckler, Harley \& Sarah Winfrey, Greg A. Wingfield, Maud Witschy, Roy Witschy, Robert H. Wolcott, Carl Wolfe, Lloyd R. Wolfe, Duane A. Wolff, Gertrude Wood, Robert Wood, W. S. Wood, Travis Wooten, Gregory Wright, Ray S. Wycoff.

P. H. Young, Shaw R. Young, V. Young, William Youngworth, Don Yung.

C. Fred Zeillemaker, B. L. Zeller, John T. Zimmer. 


\section{METHODS}

I have included all species which have been suspected of, or reported as breeding in the state, including introduced, extinct and extirpated species. Also included are species whose reported breeding may be suspect, or whose identity is open to question. All have been included so a complete list could be presented in one volume. Documentation of breeding is included when available, and inadequate documentation is discussed in cases where it is lacking or in doubt. Other species are included if they breed just outside our borders but are likely to breed here in the future. They are included to alert observers to their presence as possible breeders, so that an effort might be made to document breeding behavior.

When the Nebraska Territory was carved from the Louisiana Territory in 1854, it included parts of the present states of Colorado, Wyoming, Montana, all of Nebraska, and both South and North Dakota. The area now designated 'Nebraska' has changed repeatedly since statehood in 1867. An area along our northeastern border has been added at the expense of South Dakota (Curd 1999). Where the Missouri River formed the border, channel changes have left parts of Nebraska isolated in Missouri and lowa, and parts of lowa stranded in Nebraska. The only area which involves the nest records I found is Carter Lake, lowa, now surrounded by Nebraska. Numerous early collectors worked around 'Cut Off Lake' under its various designations. Reviewing those reports, and examining the original nest cards, led me to conclude that pinpointing their exact locations was impossible in relation to where the border was located at various times. While the stated location might be: Cut-off Lake, Omaha, or East Omaha, or the swamp south, or east of, Cutoff Lake, the county was invariably listed as Douglas County. Therefore I have chosen to treat those records, from 1880 through 1917, as Nebraska records.

The taxonomy and nomenclature used follows the Checklist of North American Birds, 7th edition ( American Ornithologists' Union 1998), with revisions through the 60th Supplement (Chesser et al. 2019). Botanical nomenclature follows The Flora of Nebraska (Kaul et al. 2011). Mammalian nomenclature follows Mammals of Nebraska (Genoways et al. 2008).

In all, more than 15,150 reports, and records of 276 species, were reviewed. Some species have hundreds of well-documented records available, while documented records of as many others number in the single digits. Some of the best-documented are those on the state or federal lists of threatened or endangered species which have been the subject of special study. For such species, enough data is available to reliably determine the range of breeding dates, clutch sizes, nesting habitat and nest placement. For many other species the available information is pitifully inadequate. Nearly all species are in need of further study. We have proof of breeding by a number of species only by having found adults with young, but for which a nest has never been reported. 


\section{THE SPECIES ACCOUNTS}

The following accounts include 245 species which for I have found acceptable documentation. Also included are seven species for which documentation is incomplete, which breed nearby, or have been reported often enough that I think they probably have bred, or will likely do so in the future. Those species are: Snow Goose, Lesser Scaup, Black Rail, Least Flycatcher, Evening Grosbeak, MacGillivray's Warbler, and Prairie Warbler.

The remaining 24 species are not accepted because I could not find adequate documentation of breeding. These include: Crested Tinamous, Passenger Pigeon, Broad-tailed Hummingbird, Yellow Rail, Solitary Sandpiper, Lesser Yellowlegs, Greater Yellowlegs, Ring-billed Gull, American Three-toed Woodpecker, Monk Parakeet, Yellow-bellied Flycatcher, Blackcapped Vireo, Blue-headed Vireo, Winter Wren, Western Bluebird, Hermit Thrush, American Tree Sparrow, Clay-colored Sparrow, Rusty Blackbird, Northern Waterthrush, Tennessee Warbler, Nashville Warbler, Virginia's Warbler, and Mourning Warbler.

\section{SPECIES WITH FEW DOCUMENTED RECORDS}

\begin{tabular}{|l|l|l|l|l|l|}
\hline \# of records & 0 records & 1 record & $2-5$ records & $6-10$ records & Totals \\
\hline \# of species & 3 species & 13 species & 47 species & 32 species & 95 species \\
\hline$\%$ of species & $1.1 \%$ & $4.7 \%$ & $17 \%$ & $11.6 \%$ & \\
\hline Total species & & & & & $34 \%$ \\
\hline
\end{tabular}

\section{TERMINOLOGY}

The following terms were adapted from various sources, including (Steenhof et al. 2017, Van Tyne and Berger 1959).

Clutch: A complete set of eggs for a single nesting, may be quite variable in some species. Clutch size: The total number of eggs laid by one female for a single nesting.

Brood/ brood size: The number of young in a single nesting. By itself, this information is less useful than clutch size because the number of young hatched is often fewer than the number of eggs laid.

Double-, or multiple- brooded: Species regularly rears more than one brood per season, e.g. phoebes usually raise two broods, Rock Pigeons start breeding when night-time temperatures stay above freezing, and continue until late fall or early winter.

Fledged: Young birds no longer in the nest; may, or may not, still be with or dependent on, the parents.

Fledgling: A fully-feathered young bird that has voluntarily left the nest but has not dispersed from the nesting territory.

Hemi-marsh: A shallow, marshy lake, with isolated stands of emergent vegetation (cattail, bulrush, etc.) surrounded by open water. Due to the surrounding open water, the isolated stands might offer increased protection to nesting colonial water-birds from mammalian predators. Good examples include Beem Lake/Avocet WMA at Hyannis, Grant Co., and Doc Lake at Whitman, Hooker Co.

Hypothetical breeder: I do not use this term. Either evidence of breeding has, or has not, been documented. Where others may use this term, I present the available evidence, or discuss the lack thereof, in the account. 
Nestling: A young bird that has not yet left the nest.

Record: A report of breeding activity with complete basic information: date, location, species identification, breeding activity noted, site of nest, clutch/brood size, and observer's name.

Report: A report of breeding activity, but lacking some basic documentation. Many published reports, and many of the Cornell Nest Cards, lacked one or more of the above, either because of space limitations for publishing, the nest contents were not seen, etc. Despite this lack, many reports did provide some information, e.g. if a nest with eggs was reported with its date, it could be used to help define the egg date range for the species.

Second attempt / replacement clutch: Indicates a failed first attempt of the season, due to predation, storm, etc.

Threatened / Endangered: Federally ranked species of special conservation concern.

Tier I / Tier II: Species of special conservation concern at the state level, as ranked by the Nebraska Natural Legacy Project.

\section{OCCURRENCE STATUS}

Extinct: species no longer occurs anywhere.

Extirpated: species no longer breeds in Nebraska.

Sporadic: breeds in the state only rarely, and then at unexpected intervals. Others as may refer to such cases as an accidental or extra-limital breeder.

Regular: breeds in the state annually.

\section{SPECIES ABUNDANCE}

Qualifiers are largely based on the frequency of reports from the survey blocks during NBBAP II, 2006-2011. This may or may not reflect actual numbers, due to variables such as: relative ease of finding big vs. small birds, cryptically colored birds, species wariness, habitat of difficult access, or inaccessible treetop nests. The categories are defined by the percentage of the 557 blocks surveyed in which the species was found, and are my current estimates.

Sporadic: $<1 \%$ of blocks. Records not available to suggest annual nesting, e.g. Cassin's Finch, Clark's Nutcracker.

Extremely rare: $1 \%$ of blocks. Probably nest annually, e.g. McCown's Longspur, Prothonotary Warbler, Cerulean Warbler.

Rare: 2 - 9\% of blocks. Nest annually, e.g. Canvasback, Ferruginous Hawk, Black-billed Cuckoo, Pygmy Nuthatch, Cordilleran Flycatcher, Yellow-throated Vireo, Black-billed Magpie.

Uncommon: 10 - 19\% of blocks. Nest annually, e.g. Western Wood-Pewee, Northern Mockingbird, American Redstart, Ovenbird, Say's Phoebe.

Common: 20 - 49\% of blocks. Nest annually, e.g. Bank Swallow, White-breasted Nuthatch, House Finch, Eastern Meadowlark, Red-bellied Woodpecker. Abundant: $>50 \%$ of blocks. Nests annually, e.g. Mallard, Great Blue Heron, Killdeer, Redheaded Woodpecker, Eastern Kingbird, Brown-headed Cowbird. 


\section{SPECIES ACCOUNTS}

The species accounts use the following format:

Common and scientific names.

Number of records / reports reviewed.

First record, with its citation, followed by 4 - 8 other records when available which: show museums that house our specimens, identify early collectors, locations where a species formerly bred, when eggs collected at a site on the same date now reside in different collections, records not previously published in the literature.

Status of the species: native vs. introduced, regular vs. irruptive vs. sporadic breeder, common regular vs. rare or localized.

A brief description of species current breeding range in the state, based NBBAP II. May also include comments on range or population changes.

Habitat used, nest site location, height, number in sample.

Number of egg dates, egg date range, bulk of egg dates with \% noted.

Number of clutches, usual clutch size, range, mean, mode, single vs. multiple nestings. Cowbird parasitism, \% of nests parasitized. 


\section{Family Tinamidae (Tinamous)}

Crested Tinamou, Eudromia elegans. An introduction was attempted by the Nebraska Game and Parks Commission in Dundy County in 1970. No evidence of reproduction or survival was reported (Editor 1971).

\section{Family Anatidae (Geese, Swans, Ducks)}

Black-bellied Whistling-Duck, Dendrocygna autumnalis. Two records. On 28 September 2019 Kelly Krechmer found an adult female with 9 young at Funk Lagoon, Phelps Co. (eBird.org). Later, on 16 October 2019 Mark and Ed Brogie noted most likely the same pair with 9 half-grown at the same site (eBird.org).

Snow Goose, Anser caerulescens. Three reports, none with adequate documentation extant. Normally a migrant that breeds far to the north. A nest with six eggs was found near Kearney in1908, but had been destroyed by a predator (Black 1920). A late report was received with inadequate documentation was of pair with young capable of only limited flight (Randy Stutheit, pers. comm.). Any such sightings should be investigated for evidence of breeding.

Canada Goose, Branta canadensis. Fifty-four nest records reviewed. First record: Nest with 5 eggs noted on 23 April 1985 at VNWR, Cherry Co. (Len McDaniel, pers. comm.). He also reported nests with 4 eggs on 6 April 1987, 7 eggs on 10 April 1989, and 5 eggs on 9 April 1992, all at VNWR, Cherry Co. (Len McDaniel, pers. comm.). Historically the species bred widely but was extirpated following European settlement, after which reintroduction took place from the 1930s through the 1980s (Sharpe et al. 2001). Now a common breeder, breeding near water sources almost statewide. Nests are usually placed on the ground, on muskrat lodges, or in artificial nest tubs. Thirty egg dates: 30 March -4 June ( 6 - 30 April $=77 \%$ of reports). Clutch sizes reported: 22 , usually 4 - 5 eggs, sometimes 6 - 7, mean 3.8, mode 5 .

Trumpeter Swan, Cygnus buccinator. Thirty-six reports reviewed. First modern report in Nebraska was in 1964 (Forsberg 1995). Due to the special status of this Tier I species, plus the danger of abandonment due to disturbance, there are almost no individual nest reports. A 2001 - 2002 study done in the Sandhills under auspices of the U. S. Fish and Wildlife Service, revealed egg dates of 15 April - 21 May, hatch dates of 21 May - 27 June, and 90 - 120 days to first flight. Clutches of 4 - 5 eggs were reported on lakes of 37 - 425 acres (15 - 170 hectares) (Farrar 2002). Since first reported, the birds have spread throughout the Sandhills and beyond. Common, regular breeder, highly territorial, a lake is usually occupied by only a single pair. As more of the larger lakes become occupied, breeding now sometimes occurs on wetlands of only 1 - 2 acres (0.5 - 1 hectare).

Wood Duck, Aix sponsa. Thirty-four records reviewed. First record: On 13 May 1953 a nest with 13 eggs was reported near Wymore, Gage Co. On 15 May the female called 12 young from the nest and led them to water (Patton 1953). A. Kenitz reported two nests in nest boxes, each with 9 eggs, on 23 July 1983 near Scottsbluff, Scotts Bluff Co. (Alice Kenitz, pers. comm.). Kenitz reported a nest with 3 eggs on 5 May 1984 near Scottsbluff, Scotts Bluff Co. (CNRCP, \#2517). Abundant, expanding breeder. Nests 6 - $32 \mathrm{ft}(2-10 \mathrm{~m})$ up, in natural cavities or nest boxes, in riparian areas or up to a mile $(2 \mathrm{~km})$ distant, or in 
towns. Four egg dates: 5 May - 23 July. Four clutch sizes reported: 3 - 13 eggs, mean 10.3, mode 9. Thirty-one broods: 4 - 10 young, mean 7.6, mode 10. Adults with fledged young noted 5 May - 22 August.

Blue-winged Teal, Spatula discors. Five hundred forty-four records. First record: I. S. Trostler collected two nests, each with 7 eggs on 21 June 1895 near Cody, Cherry Co., (WFVZ, Cat. \#174893, \#175209). L. Bruner took 6 eggs on 13 May 1897 at West Point, Cuming Co. (UKBI, Cat. \#95548). J. S. Hunter took 12 eggs on 4 June 1900 at Trout Lake, Cherry Co. (UNSM, Cat. \#ZM08162). T. C. Stephens noted 8 eggs on 13 June 1910 at Silver Lake, Dakota Co. (Stephens 1957). F. H. Shoemaker photographed a nest with 8 eggs on 25 July 1911 at Trout Lake, Cherry Co. (Shoemaker undated). H. C. Oberholser noted a nest with 12 eggs on 1 June 1915 at Cody Lake, near Cody, Cherry Co. (Oberholser and McAtee 1920). Common breeder. Nests on ground near shallow ponds and lakes. Two hundred eighty-five egg dates: 22 April - 25 July (7 May - 11 June $=79 \%$ of egg dates). Clutch sizes reported: 544, usually 7 - 11 eggs, sometimes 1 - 19, mean 8.8, mode 10. Cinnamon Teal, Spatula cyanoptera. Three records. First record: W. W. Bennett found a nest with 8 eggs on 10 June 1937 at CLNWR, Garden Co. (Bennett 1937). M. J. Helsinger found a nest with 9 eggs on 2 June 1985 also at CLNWR (Helsinger 1985b). In 2007, M. French, FWS biologist there, commented: "there seems to be a stable population of two breeding pairs of Cinnamon Teal at CLNWR."(Marlin French, pers. comm.) Extremely rare, likely a regular breeder but rarely documented. Nests on ground in wet grassy areas near shallow lakes. Five egg dates: 1 - 11 June. Three clutch sizes reported: 8 - 9 eggs, mean 8.7, mode 9.

Northern Shoveler, Spatula clypeata. One hundred four records. First record: C. E. Mickel took 1 egg on 18 June 1916 near Morrill, Scotts Bluff Co. (UNSM, Cat. \#ZM08166). B. Sage noted a nest with 7 eggs on 4 June 1969 at VNWR, Cherry Co. (CNRCP, \#325). He also reported a nest there with 11 eggs on 14 June 1972 (CNRCP, \#326). L. McDaniel noted two nests, each with 7 eggs, on 29 May 1987 at VNWR, Cherry Co. (Len McDaniel, pers. comm.). M. French noted 2 nests, each with 7 eggs on 5 June 2006 at CLNWR, Garden Co., and on 24 May 2007, he noted two nests there, with 6 \& 8 eggs, respectively (Marlin French, pers. comm.). Common, regular breeder almost statewide. Nests on ground near shallow ponds. One hundred eleven egg dates: 4 May - 26 June (8 May - 7 June $=75 \%$ of dates). Clutch sizes reported: 104, usually 7 - 10 eggs, sometimes 1 - 13, mean 7.9, mode 7.

Gadwall, Mareca strepera. Three hundred sixty-eight records. First record: At Sweetwater Lake, VNWR, Cherry Co., H. Sather found a nest with 1 egg on 5 June 1952 (Sather undated). L. McDaniel found a nest with 7 eggs on 5 June 1979 VNWR, Cherry Co. On 9 June 1987 he found two nests there, each with 8 eggs, and on 28 May 1990 he found two nests there, each with 11 eggs (Len McDaniel, pers. comm.). M. French noted two nests, each with 7 eggs on 14 May 1992 at CLNWR, Garden Co. (Marlin French, pers. comm.). Uncommon widespread breeder. Nests placed on ground in grass or forbs near lakes. Three hundred sixty-eight egg dates: 5 May - 9 July (20 May - 11 June $=80 \%$ of dates). Clutch sizes reported: 344, usually 7 - 11 eggs, sometimes 4 - 14, mean 9.1, mode 9. 
American Wigeon, Mareca americana. Seven records. First record: W. M. Sharp found a nest with 6 eggs on 22 June 1938 at Dewey Lake, VNWR, Cherry Co. (Sharp 1939). L. McDaniel found two nests, with 9 \& 10 eggs on 2 June 1993 at VNWR. He also found a nest with 9 eggs on 12 May 1998 a nest with 10 eggs on 25 May 1998 and another with 11 eggs on 1 June 1998 all at VNWR, Cherry Co. (Len McDaniel, pers. comm.). Rare, regular breeder in western Sandhills, with a single record in the Rainwater Basin (Joel Jorgensen, pers. com.) Nests on the ground near water. Six egg dates: 25 May - 22 June. Clutch sizes reported: 7, usually 9 - 10 eggs, sometimes 6 -11, mean 9.3, mode 10.

Mallard, Anas platyrhynchos. Seventy-six records. First record: L. Bruner took a set of 9 eggs on 12 May 1897 near West Point, Cuming Co. (UKBI, \#95549). W. C. Smith took 1 egg on 11 June 1897 near Long Pine, Brown Co. (SBM, Cat. \#57). R. D. Hoyt took 10 eggs on 28 May 1914 at Antioch, Sheridan Co. (UFMNH, Cat. \#2126). A. M. Brooking took 5 eggs on 1 August 1915 at Inland, Clay Co. (HM, Cat. \#02149). J. H. Sather noted a nest with 9 eggs on 31 May 1952 at Ballard's Marsh, Cherry Co. (Sather undated). Abundant, regular breeder statewide. Nests on ground, usually near water, sometimes in residential or urban areas, up to a half mile $(1 \mathrm{~km})$ from water. One hundred thirty-nine egg dates: 3 April - 15 July (5 May - 17 June = 75\%). Clutch sizes reported: 76, usually 6 - 10 eggs, sometimes $4-25$, mean 8.4 , mode 8 . Clutches larger than 12 eggs are likely the product of more than one female.

Northern Pintail, Anas acuta. Forty-nine reports. First record: H. C. Oberholser found a nest with 9 eggs on 6 June 1915 at Dewey Lake, VNWR, Cherry Co. (Oberholser and McAtee 1920). H. C. Weakly reported a nest with 6 eggs in 1939 at the North Platte Experiment Station, Lincoln Co. (Weakly 1939). B. Sage reported a nest with 10 eggs on 24 June 1969 at VNWR, Cherry Co. (CNRCP, \#776). H. Gunderson reported a nest with 6 eggs on 6 June 1967 at CLNWR, Garden Co. (CLNWR archives). C. E. Hoger reported a nest with 4 eggs on 5 June 1973 near Genoa, Nance Co. (CNRCP, \#813). L. McDaniel noted a nest with 6 eggs on 17 May 1984 at VNWR, Cherry Co. (Len McDaniel, pers. comm.). Uncommon, apparently declining regular breeder. Nests on ground near shallow ponds. Fifty-one egg dates: 22 April - 30 June (11 May - 7 June =63\%). Clutch sizes reported: 49, usually 6 - 9 eggs, sometimes 4 -11, mean 7.6, mode 9.

Green-winged Teal, Anas crecca. Four records. First complete record: On 20 May 1919 a nest with 2 eggs was found by A. M. Brooking and C. A. Black in Garden Co. (HM, Cat. \#01791A). W. Colt found a nest with 4 eggs at Badger, Holt Co., but did not provide a date (Swenk 1895 - 1915). W. M. Sharp reported a nest with 7 eggs at VNWR, Cherry Co. in June 1938 (Sharp 1939). L. McDaniel found a nest with 11 eggs on 31 May 1978 at Hackberry Lake, VNWR, Cherry Co. (Len McDaniel, pers. comm.). Rare, probably regular, but local breeder. Three egg dates: 20 May - 22 June. Clutch sizes reported: 4, of $2,4,7$, and 11 eggs.

Canvasback, Athya valisineria. Twenty-two reports, five records. First record: H. Harris found a nest with eggs on 2 June 1923 near Nenzel, Cherry Co. (UKBI, \#74094). A nest with 11 eggs was monitored 7 - 11 June 1965 at CLNWR, Garden Co. (Sharpe and Payne 1966). L. McDaniel found 2 nests, each with 4 eggs, at Mule Lake, VNWR, on 4 June 1978 and found another nest with 7 eggs on 15 May 1980 at Middle Marsh Lake, VNWR, Cherry Co. (Len McDaniel, pers. comm.). Rare, regular but local breeder in western Sandhills. 
Builds its semi-floating nests in rushes and cattails. Ten egg dates: 14 May - 11 June (1 11 June $=90 \%)$. Clutch sizes reported: 4 , usually 4 - 7 eggs, sometimes 11, mean 6.5, mode 4 . Thirteen broods: mean 6 , no mode.

Redhead, Aythya americana. Forty-one records. First record: On 11 June 1922 H. Harris found a nest with 1 heavily incubated egg near Nenzel, Cherry Co. (UKBI, Cat. \#74090). P. H. Young took 9 eggs on 2 June 1923 at Simeon, Cherry Co. (USNMNH, Cat. \#B40386). A. M. Brooking took 6 eggs on 9 July 1929 at Inland, Clay Co. (HM, Cat. \#07834). W. Krummes noted 10 eggs on 21 May 1933 at CLNWR, Garden Co. (CLNWR archives). J. H. Sather noted a nest with 7 eggs on 31 May 1949 and a second nest there with 17 eggs, on 22 May 1951 at VNWR, Cherry Co. (Sather undated). J. Wilbrecht noted a nest with 8 eggs on 5 June 1967 at CLNWR, Garden Co. (CNRCP, \#137). L. McDaniel noted a nest with 18 eggs on 2 June 1984 at VNWR, Cherry Co. (Len McDaniel, pers. comm.). Rare regular breeder, especially in the Sandhills and Rainwater Basin. Nests are built over water in rushes and cattails. Forty-seven egg dates: 1 May - 28 June (10 May - 13 June = 77\%). Clutch sizes reported: 42, usually 6 - 12 eggs, sometimes 13 - 18 . Noted for 'dumping' eggs, or parasitizing nests of their own and other species (Palmer 1976).

Ring-necked Duck, Aythya collaris. Four reports. One record. No nest records. On 26 September 2019, USFS biologist Greg Wright photographed an adult female with four well-grown young at the Nebraska National Forest, McKelvie Division, Cherry Co.(Greg Wright, pers. comm.). CLNWR annual reports in 1972 and 1978 mention numbers of young raised to flight stage, with no further details. Current staff biologists there could provide no further details (Marlin French, pers. comm.). Citing Oberholser and McAtee (1920), Ducey (1988) listed breeding in Brown, Cherry, Garden, and Morrill counties, but Oberholser only mentioned observing the species on lakes in Brown and Cherry counties, but not the lakes in Morrill and Garden counties, and stated that "... it doubtless occurs there, at least occasionally." While he reports nests, eggs, and young of other ducks, he does not make mention of nesting or seeing young of this species. Any indication of breeding should be investigated for evidence of breeding.

Lesser Scaup, Aythya affinis. No confirmed breeding records. The most intriguing reports are from the CLNWR area in Garden Co. where summering birds are sometimes reported. Ducey (1988) cites Oberholser and McAtee (1920) as breeding in Cherry Co., but their report comments that birds observed there, "...seemed to be belated migrants, though it is barely possible that the species occasionally breeds in this region." There are other reports of young that cannot now be verified. Any indication of breeding should be investigated for evidence of breeding.

Bufflehead, Bucephala albeola. One documented record: Adult with 4 non-flying young on 24 June 2000 at Hagen Lake, Brown Co. found by Nick Lyman, NGPC waterfowl biologist (Mollhoff 2001b). Sporadic breeder. There is also a report of young in 1974, at CLNWR, Garden Co. but with no corroborating details. Breeding season observations should be investigated for evidence of breeding.

Hooded Merganser, Lophodytes cucullatus. Five records. First record: In mid-July 1900, as a high school student M.H. Swenk, "... saw a female with six or seven young on the Blue [River], and secured a young bird." (Swenk 1902b). R. C. and D. J. Rosche reported a brood with 5 young of the year in Grant Co. (Grzybowski 1995). On 5 May 19974 
downy, day-old young were found in Waterloo, Douglas Co. (John Dinan, pers. comm.). L. and C. Falk found a female with 9 young at Nebraska City, Otoe Co., on 20 May 2005 (Silcock 2005a). A female with 3 downy young was reported in Omaha, Douglas Co. on 9 May 2008 (Silcock 2008a). Rare, probably regular breeder, especially in riparian habitat near open water. Cavity nester. No nests have been reported, likely because the male leaves the area shortly after incubation begins, thus not drawing attention to the nesting female (Dugger et al. 1994). When found with young, the wary female quickly hides the young in vegetation before performing vigorous distraction display. Six brood sizes reported: 2 - 9 young. Breeding season observations should be investigated for evidence of breeding.

Common Merganser. Mergus merganser. Five records. First record: E. A. Kiborz found a female with 6 young on 27 July 1968 at Victoria Springs SRA, Custer Co. (Bennett 1969). On 2 July $2007 \mathrm{~J}$. Luchsinger found a brood of 8 small downy young, as well as a second brood of 4 half-grown young at the Norden bridge, Keya Paha Co. (Jim Luchsinger, pers. comm.) At the same site, a female with chicks was noted on 7 May 2017 and later, on 7 July a female with 5 non-flying young were photographed several miles downstream (Gordon Warrick, pers. comm., Silcock 2017). Extremely rare breeder in riparian woodland. No egg dates. Adults with dependent young have been noted 7 May - 7 July.

Ruddy Duck, Oxyrua jamaicensis. Eighteen records. First record: A. M. Brooking collected a set of 3 eggs on 8 June 1915 at Inland, Clay Co. (HM, Cat. \#02117). F. J. Keller noted three nests, each with 9 eggs, and a fourth nest with 5 eggs, on 8 June 1931 near Antioch, Sheridan Co. (Swenk 1931). W. T. Krummes noted a nest with 2 eggs on 22 May, a nest with 9 eggs on 9 June, and three nests with 3, 7, and 8 eggs, on 3 July 1933 at CLNWR, Garden Co. (CLNWR archives). J. H. Sather noted a nest with 3 eggs on 29 June 1950 and another with 2 eggs on 12 June 1953 at VNWR, Cherry Co. (Sather undated). Uncommon, regular breeder, on shallow ponds, nests placed over water in rushes and cattails. Thirty-two egg dates: 22 May - 27 July. Clutch sizes reported: 19, usually 6 - 9 eggs, sometimes 2 -12, mean 6.3, mode 6 .

\section{Family Odontophoridae (Quails)}

Northern Bobwhite, Colinus virginianus. Thirty-four records. First record: A nest with 16 eggs was reported on 19 May 1889 but without a specific location (Taylor and VanVleet 1889). N. S. Goss collected a set of 9 eggs on 14 May 1890 in Lincoln, Lancaster Co. (UKBI, Cat. \#95544). C. Pew took 10 eggs on 12 July 1890 at Hebron, Thayer Co. (CAS, Cat. \#4565). A. J. Pyfer took 22 eggs on 5 June 1891 at Odell, Gage Co. (ROM, Cat. \#502085). L. R. Sabine took 20 eggs on 6 June 1896 at Omaha, Douglas Co. (WFVZ, Cat. \#99502). W. Tout noted a nest with 17 eggs on16 May 1897 near Bradshaw, York Co. (Tout 1901). J. S. Hunter took 25 eggs on 15 June 1900 at Lincoln, Lancaster Co. (UNSM, Cat. \#ZM08277). Abundant regular breeder, ground nester at grassland/woodland edge, population highly variable dependent on habitat availability and severity of winters. Twenty-three egg dates: 1 May - 24 August, (29 May - 30 June = 83\%). Widely scattered dates may represent double broods, or replacement clutches. Clutch sizes reported: 34 , usually 8 - 18 eggs, sometimes 2 - 25, mean 11.2, mode 14 . 
Scaled Quail, Callipella squamata. One report. Privately introduced in 1957, the birds expanded rapidly for several years. None were reported after 1962, following several consecutive severe winters in the area where the birds were released (Mathisen and Mathisen 1960). No nest records have been found.

California Quail, Callipella californica. One report. Unsuccessfully introduced. A pair released by NGPC at Norfolk, Madison Co. in 1939, produced a covey at the site. A single bird was found roadkilled nearby on 25 May 1940 (Halbert 1940). No nests were reported.

\section{Family Phasianidae (Grouse, Pheasants, Turkeys)}

Chukar, Alectoris chukar. Three records. First record: Following release of birds by NGPC in 1938, a nest with 12 eggs hatched on 31 May 1940 at Norfolk, Madison Co. (Halbert 1940). A more recent report of a nest in a housing area in Omaha on 24 July 2001 was attributed to a released bird (Silcock 2001). A nest with eggs at Grand Island, Hall Co. on 6 June 2010 also seems attributable to escaped birds from a game bird farm (Randall Foland, pers. comm.). Introduced by NGPC but the effort was ultimately unsuccessful. Isolated reports, mostly from the Panhandle, were received until the 1980s (Sharpe et al. 2001).

Gray Partridge, Perdix perdix. Eight reports, one record. Only nest record: L. Einemann, found a nest with one egg, plus the shells of about 15 hatched eggs, on 15 June 1980 near West Point, Cuming Co. (Einemann 1980). Introduced Eurasian game bird, releases were widely scattered across the state during 1920s - 1950s and were initially successful but later declined. Probably an extremely rare breeder with only a few current reports from a small area in the northeast (Mathisen and Mathisen 1960, Mollhoff 2016). Reports now are from an area of grassland-cropland with mix of scattered shrubby woodland.

Japanese Quail, Coturnix japonica. Two reports. One partially documented record. About 76,600 birds were introduced at Norfolk, Madison Co., and adjacent northeast Nebraska beginning in 1957. Probably some initial reproduction but no reports of the species since 1962 (Mathisen and Mathisen 1960, Sharpe et al. 2001). There is a mounted pair, with one egg (of a set of two eggs) on display at the Hastings Museum, received from NGPC biologist D. Snyder, dated April 1957 (HM, Cat. \#29092).

Ring-necked Pheasant, Phasianus colchicus. Seventy-seven records. First record: F. M. Uhler collected one egg at Grand Island, Hall Co., 13 June 1929 (WFVZ, Cat. \#188514). P. Samms took 3 eggs on 15 July 1933 at Hastings, Adams Co. (HM, Cat. \#11092). Two nests, with 15 and 16 eggs, were found on the NOU field trip on 14 May 1938 near Superior, Nuckolls Co. (Editor, 1938). J. H. Sather noted a nest with 7 eggs on 20 June 1952 at VNWR, Cherry Co. (Sather undated). C. Wolfe reported a Greater Prairiechicken nest with 11 eggs, plus 12 pheasant eggs, on 7 June 1965 near Palmyra, Lancaster Co. (Wolfe 1965). H. J. Turner reported a nest with 4 eggs on 26 April 1966 at Holstein, Adams Co. (CNRCP, \#50). S. M. Moody noted a nest with 13 eggs on 16 June 1967 near Greeley, Greeley Co. (CNRCP, \#61). L. C. Holcomb noted a nest with 17 eggs on 15 May 1968 at Waterloo, Douglas Co. (CNRCP, \#102). Game bird introduced by individuals beginning in 1909, and by NGPC about 1915 (Mathisen and Mathisen 1960). Abundant resident across the state, with population varying with weather and availability of habitat. Ground nester in cropland and grassland. Eighty-six egg dates: 11 
April - 22 August, (25 April - 22 June $=93 \%$ ). Clutch sizes reported: 77, usually 9 - 15 eggs, sometimes 4 - 24, mean 12.2, mode 11 . Larger clutches often laid by multiple birds.

Ruffed Grouse, Bonasa umbellus. No nest reports. Formerly resident in eastern woodlands, extirpated shortly after 1900. A reintroduction attempt in 1968 failed (Sharpe et al. 2001).

Greater Sage-Grouse, Centrocercus urophasianus. No nest reports. Historically a rare breeder in shrub-steppe grasslands of northern Sioux Co. Merritt Cary (1902) reported "...a few pairs were nesting in the sage brush along Antelope and Indian creeks." Later on that trip, several young were collected in mid-July 1901. The only other reported possibility of breeding was of a single male present at a Sharp-tailed Grouse lek on 12 April 1951 in northern Sioux Co. (Levi Mohler, pers. comm.)

Sharp-tailed Grouse, Tympanuchus phasianellus. One hundred twenty-six records. First record: W. C. Smith collected an egg on 15 June 1898 near Long Pine, Brown Co. (SBM, Cat. \#53). M. A. Carriker, Jr., took 13 eggs on 23 June 1901 on Jim Creek, Sioux Co. (UNSM, Cat. \#ZM08290). J. L. Childs took 10 eggs on 29 May 1908 on the Dismal River, Thomas Co. (WFVZ, Cat. \#92298). H. Harris took 12 eggs on 23 May 1923 at Simeon, Cherry Co. (USNMNH, Cat. \#B40291). P. H. Young took an egg on 15 June 1923 at Simeon, Cherry Co. (YPM, Cat. \#ORN 142083). L. Blus noted a nest with 14 eggs on 26 May 1966 in the National Forest, Thomas Co. (CNRCP, \#7). S. Huber and M. French studied 14 radiotagged hens in 2007 - 08, at CLNWR, Garden Co. and documented 25 nests, with some of the hens making as many as 4 attempts before giving up (Steve Huber, pers. comm.). Common breeder west of Holt and Howard counties. Nests on ground in mixed-grass and shortgrass prairies. One hundred eighteen egg dates: 21 April - 6 August (28 April 23 June $=96 \%)$. Clutch sizes reported: 128, usually 8 - 14 eggs, sometimes 3 - 22, mean 9.3, mode 13.

Greater Prairie-Chicken, Tympanuchus cupido. Twenty-six records. First record: H. A. Kline took 14 eggs on 28 April 1882 in Johnson Co. (CAS, Cat.\#6961). Kline took 15 eggs on 25 May 1882 at Vesta, Johnson Co. (USNMNH, Cat. \#B43519). F. H. Chapin took 7 eggs on 16 June 1882 at Crete, Saline, Co. (UMMZ, Cat. \#239949). R. M. Barnes took 2 eggs on 30 April 1889 at Genoa, Nance Co. (FMNH, Cat. \#5992). G. P. Anderson took 10 eggs on 20 May 1898 at Cairo, Hall Co. (NYSM, Cat. \#ZO-12370). L. J. Blus and J. A. Walker studied sites in Loup, Holt, and Thomas counties 1959 - 1964, and found nest sites were chosen in fairly dense grass, with some old growth, and placed on north- and east-facing slopes of large hills with a 20 - 30\% slope (Blus and Walker 1966). Common ground nester in native mixed-grass and tallgrass prairies east of the Panhandle. Thirty-nine egg dates: 19 April - 8 July (10 May - 10 June $=79 \%$ ). Clutch sizes reported: 26, usually 7 - 12 eggs, sometimes 5 - 15, mean 11.9, mode 11.

Wild Turkey, Melagris gallopavo. Twenty-one records. First record: Capt. Charles Bendire, a founding member of the AOU, found a nest with five eggs on 21 May 1880 at Ft. Niobrara, Cherry Co. (WFVZ, Cat. \#206534). I found a nest with 3 eggs on 27 April 1989 at Ft. Robinson, Sioux Co. L. McDaniel noted that the 14 eggs in a nest hatched on 7 June 1995 at VNWR, Cherry Co. (Len McDaniel, pers. comm.). T. J. Walker reported a nest with 6 eggs on 21 May 2004 near Hershey, Lincoln Co. (Thomas Walker, pers. comm.). 
A. Reyer noted a nest with 11 eggs on 2 May 2005 in Bellevue, Sarpy Co. (Silcock 2005a). D. H. Kim noted a nest with 6 eggs on 15 May 2005 at WCT, Hall Co. (Dan Kim, pers. comm.). Abundant ground nester, usually located in or near shrubs or woodland. After hatching, two or three hens usually share duties rearing the young, and finding the hens with 15 - 27 young is not unusual. Twenty-five egg dates: 10 April - 16 July, no obvious date clusters, nests after mid-June are likely replacement clutches. Clutch sizes reported: 21, usually 10 - 12 eggs, sometimes 5 -15, mean 10.7, mode 10 .

\section{Family Podicepdidae (Grebes)}

Pied-billed Grebe, Podilymbus podiceps. Forty-one records. First record: F. H. Andrus collected a set of six eggs at Florence Lake, Douglas Co., on 26 July 1891 (WFVZ, Cat. \#50713). L. Skow took 5 eggs on 30 June 1894 also at Florence Lake (UKBI, Cat. \#95551). I. S. Trostler took a set of eggs on 8 July 1894 at Cut Off Lake, Douglas Co. (PSM, Cat. \#Bird - 11557). Trostler also took a second set of 5 eggs here on this date (NYSM, Cat. \#ZO-10896), and a third set of 8 eggs at the same site and same date (WFVZ, Cat. \#132168). G. W. Morse took 7 eggs on 3 July 1898 at Cut-off Lake, Douglas Co. (CM, Cat. \#Birds E-850). E. M. West took 9 eggs on 11 June 1899 at Cut-off Lake, Douglas Co. (UNSM, Cat. \#ZM08008). Uncommon regular solitary breeder, builds floating nest in shallow water among emergent vegetation. Sixty-five egg dates: 5 May - 26 July (28 May - 7 July $=62 \%$ ). Clutch sizes reported: 33, usually 5 - 8 eggs, sometimes 1 - 10, mean 5.8, mode 7.

Horned Grebe, Podiceps auritus. Two records of active nests. First record: I. S. Trostler collected a set of 7 well-incubated eggs near Cody, Cherry Co., on 29 June 1895 (WFVZ, Cat. \#94463). On 12 August 1898 A. A. Michell collected a set of 8 eggs in Cherry Co.(MCZ, Cat. \#357747). On 6 June 1903 R. H. Wolcott found a newly-completed empty nest at Little Alkali Lake, in northern Cherry Co. (Bruner et al. 1904). Sporadic breeder with latest nest report in 1903. Probably extirpated. Floating nests in shallow water in emergent vegetation were reported.

Eared Grebe, Podiceps nigricollis. Two hundred seventy-three records. First record: Mr. McClellean collected a nest with 6 eggs on 12 May 1888 near Nebraska City, Otoe Co.(WFVZ, Cat. \#87211). I. S. Trostler took 6 eggs on 18 June 1893 on the E. bank of Cutoff Lake, Douglas Co. (UFMNH, Cat. \#926), and a second set of 7 eggs there on the same day (UKBI, Cat. \#95552). F. B. Clinchard took 8 eggs on 16 June 1899 near Omaha, Douglas Co. (WFVZ, Cat. \#200095). E. S. Balbach took 8 eggs on 28 June 1899 near Omaha, Douglas Co. (FMNH, Cat. \#18890). A. M. Brooking took 6 eggs on 2 June 1916 at Inland, Clay Co. (YPM, Cat. \#116793). L. McDaniel noted 250 nests with 500 adults on 9 June 1982 at VNWR, Cherry Co. (L. McDaniel, pers. comm.). Rare regular breeder in the Sandhills and Rainwater Basin. Colonial, builds floating nests in emergent vegetation. Colonies of 9-250 nests have been reported, mean colony size is 122 nests. Two thousand, seven hundred forty-five dates: 2 May - 11 August (2 June - 7 July = 92\%). Clutch sizes reported: 191, usually 3 - 4 eggs, sometimes 1 - 8, mean 3.1, mode 3.

Western Grebe, Aechmorphorus occidentalis. Fifty records. First record: C. A. Black collected four eggs and one chick on 1 June 1915 from a nest on Island Lake, Garden Co. (Black 1920). On 3 June 1916 he collected 4 eggs and a chick from one nest, plus 5 eggs from 
another at the same site (Swenk 1933). C. A. Black and A. M. Brooking took 3 eggs on 17 June 1917 from there (HM, Cat. \#06270). J. Wampole and E. Fichter noted 3 eggs in each of seven nests on 21 May 1946, and collected the eggs from one of the nests at George Lake, Grant Co. (UNSM, Cat. \#ZM08001). J. Farrar noted five nests, with 2 eggs each, plus five more nests, with 3 eggs each, on 6 June 1987 north of Ashby at Alkali Lake, Cherry Co. (Jon Farrar, pers. comm.). Uncommon regular colonial breeder, builds its floating nests in cattails and rushes, usually in marshy Sandhills lakes. Seven colonies of 2 - 34 pairs reported, usually 5 - 12 pairs. One hundred two egg dates: 21 May - 11 July ( 3 - 26 June $=89 \%$ ). Clutch sizes reported: 57 , usually $2-3$ eggs, sometimes $1-5$, mean 2.8, mode 3.

Clark's Grebe, Aechmorphorus clarkii. Five reports. One nest record: I found a nest with two eggs at Willy Lake, Sheridan Co., 23 June 2002. A followup visit on 19 July found the adults feeding 2 begging young (Mollhoff 2004b). The nest was in a Western Grebe colony of six nests. Three broods have been reported, each with two young. Nest habitat and construction are indistinguishable from Western Grebe.

\section{Family Columbidae (Pigeons, Doves)}

Rock Pigeon, Columba livia. Fifty records. First record: Mrs. C. Collister found a nest with 2 eggs in late June 1949 near Paxton, Keith Co. (Collister 1950). J. F. Anderson reported a nest with 2 eggs on 13 June 1965 at Beaver Crossing, Seward Co. (CNRCP, \#7). I found a nest with 2 eggs on 18 March 1984 at Primrose, and another nest with 2 eggs on 7 March 1986 at Loretto, Boone Co. W. Glenn noted a nest with 2 eggs on 15 March 2007 near Powell, Jefferson Co. (William Glenn, pers. comm.). I noted a nest with 2 eggs on 30 October 2008 at Greenwood, Cass Co. Common introduced breeder in communities statewide, usually found near livestock feeding or grain storage operations. Nests built on ledges in open buildings or beneath bridges. Thirty-nine egg dates: 6 March - 21 November, with no date clusters. Nests almost year-round except during extended periods of sub-freezing temperatures. Multiple broods. Clutch sizes reported: 34 , usually 2 eggs, sometimes 1 or 3, mean 1.7, mode 2 .

Eurasian Collared-Dove, Streptopelia decaocto. Five records. First record: Two young fledged from a nest on 19 May 1998 in Kearney, Buffalo Co. (Silcock and Jorgensen 1998). R. Harding noted a nest with 1 egg on 7 April 2000 at Kearney, Bufalo Co. (Silcock 2000a). I found a nest with 2 eggs on 21 March 2007 at Ashland, Saunders Co., and another nest with 2 eggs on 4 June 2007 at Sacramento-Wilcox WMA, Phelps Co. L \& J Poppe reported a nest with 2 eggs on 13 October 2009 in Scribner, Dodge Co. (Janis Poppe, pers. comm.) Common (now abundant) invasive resident. First noted in 1997, now resident in every county and found wherever grain is available. Found around human habitation, two nests reported in trees were 22-28 ft (7-9 m) up. Nest-building noted by 23 February. Five egg dates: 21 March - 13 October. Clutch sizes reported: 4, usually 2 eggs, mean 2.0, mode 2. Up to four broods have been reported per year.

Passenger Pigeon, Ectopistes migratorius. Five reports. Extinct. May have nested in the state but there are no definite records. There is a mounted group of three birds in the Hastings Museum (HM, Cat. \#2914) collected at Cook, Johnson Co., but without a date or collector identified. Also included in the case is an egg without documentation (HM, 
Cat. \#26308). The latest record in the state is of a flock of 15 flying over the house of G. W. Sabine in Omaha, Douglas Co. on 28 November 1895 (Trostler 1896).

White-winged Dove, Zenaida asiatica. Three records. First record: A young bird blown out of its nest by a storm was found by C. Noecker on 21 June 2005 in Albion, Boone Co. (Mollhoff 2005b). On 26 July 2006 a pair with a single chick was noted at the same location (Coleen Noecker, pers. comm.). At Kearney, Buffalo Co., adults with 2 young were reported on 10 July 2014 (Silcock 2014a). J. Holst photographed fledged young from a first clutch on 11 July 2017 near Mead, Saunders Co., and a nest with 2 eggs of the second clutch on 14 July 2017 (Jane Holst, pers. comm.). Rare breeder, but increasing. Reports are from residential or park-like campus areas. Nest-building reported as early as $18 \mathrm{March}$, and adults with dependent young reported as late as 10 September. Two is the only clutch size reported.

Mourning Dove, Zenaida macroura. Four hundred twenty-two records. First record: N. H. Goss collected a set of 2 eggs on 3 July 1890 in Lincoln, Lancaster Co. (UKBI, Cat. \#95628). W. C. Smith took 1 egg on 3 June 1896 near Long Pine, Brown Co. (SBM, Cat. \#27). D. E. Jones took 2 eggs on 2 June 1899 in Garfield Co. (CM, Cat. \#E1139). M. A. Carriker, Jr., took 2 eggs on 1 June 1901 in the Prairie Dog Creek badlands, Sioux Co. (UNSM, Cat. \#ZM08298). R. H. Wolcott took 2 eggs on 16 May 1898 at Lincoln, Lancaster Co. (UNSM, Cat. \#ZM08304). J. L. Childs took 2 eggs on 30 May 1908 near Thedford, Thomas Co. (FMNH, Cat. \#19952). D. H. Leavitt took 2 eggs on 3 May 1920 at Omaha, Douglas Co. (MCZ, Cat. \#354487). Abundant breeder statewide, places nests on the ground or in trees, sometimes placed atop old nests of other species, found in nearly all habitats. Multiple broods. Four hundred twenty-one egg dates: 27 March - 17 September (3 May - 3 July $=84 \%$ ). Clutch sizes reported: 422 , usually 2 eggs, sometimes 1 or 3 , mean 1.9 , mode 2 .

\section{Family Cuculidae (Cuckoos)}

Yellow-billed Cuckoo, Coccyzus americanus. Forty-nine records. First record: N. H. Goss collected two sets, each of two eggs, on 25 May 1889 in Lincoln, Lancaster Co. (UKBI, Cat. \#95636, \#95637). J. C. Crawford, Jr., took 4 eggs on 6 June 1898 at West Point, Cuming Co. (UNSM, Cat. \#ZM08442). G. P. Anderson took 3 eggs on 10 July 1900 at Dannebrog, Howard Co. (MVZ, Cat. \#1214). J. L. Childs took 5 eggs on 29 May 1908 near Thedford, Thomas Co. (FMNH, Cat. \#20803). D. H. Leavitt took 1 egg on27 June 1923 at Omaha, Douglas Co., (MCZ, Cat. \#354666). H. E. McClure noted a nest with 4 eggs on 26 June 1943 at Ord, Valley Co. (CNRCP, \#264). Common, regular but declining breeder, nests in shrubby woodland edge. Sixty-one nests, usually $1.5-10 \mathrm{ft}(0.5-3 \mathrm{~m})$ high, but sometimes 19 - $40 \mathrm{ft}$ (6 - $12 \mathrm{~m}$ ). One hundred thirty-two egg dates: 21 May - 29 August ( 1 June -31 July $=77 \%$ ). Clutch sizes reported: 49, usually 2 - 4 eggs, sometimes 1 - 6 , mean 3.2, mode 4.

Black-billed Cuckoo, Coccyzus erythrophthalmus. Twenty records. First record: W. L. Carpenter collected a nest with two eggs on 2 June 1874 at Omaha, Douglas Co. (USNMNH, Cat. \#B17366). N. S. Goss took 3 eggs on 18 June 1890 at Belmont, Dawes Co. (UKBI, Cat. \#95640). W. C. Smith took 1 egg on 25 May 1897 near Long Pine, Brown Co. (SBM, Cat. \#41). J. L. Childs noted a nest with 1 egg on 29 May 1908 near Thedford, Thomas Co. 
(Childs 1908). J. T. Zimmer took 4 eggs on 8 June 1912 at the National Forest, Thomas Co. (Zimmer undated). W. Tout noted 3 eggs at North Platte, Lincoln Co. (Tout 1947). H. J. Turner reported 3 eggs on 9 July 1965 at Holstein, Adams Co. (CNRCP, \#6). Rare regular, but declining, breeder. Places its low nests in shrubby woodland edge habitats. Sixty-three egg dates: 25 May - 14 August (8 June - 30 July $=74 \%$ ). Clutch sizes reported: 20, usually 2 - 3 eggs, sometimes $1-4$, mean 3.0 , mode 3 .

\section{Family Caprimulgidae (Goatsuckers)}

Common Nighthawk, Chordeiles minor. Thirty records. First record: L. Bruner collected a nest with two eggs on 23 June 1894 near Swan Lake in SW Holt Co. (UNSM, Cat. \#ZM08498). D. E. Hatch noted 2 eggs on 10 July 1966 at Toadstool Park, Sioux Co. (CNRCP, \#25). Z. Uridil noted 2 eggs on 9 July 1971 near Chadron, Dawes Co. (CNRCP, \#166). R. A. Lock noted 2 eggs on 16 June 1975 near Crawford, Dawes Co. (CNRCP). J. J. Dinan noted 2 eggs on 5 June 1982 at Gilbert-Baker WMA, Sioux Co. (John Dinan, pers. comm). Common regular breeder statewide; its ground nests are found on gravel rooftops, open grassland, rocky outcrops, or among scattered trees. Forty-seven egg dates: 29 May - 3 August ( 29 May - 19 June $=65 \%$ ). Clutch sizes reported: 30 , usually 2 eggs, sometimes 1 - 4, mean 1.9, mode 2 .

Common Poorwill, Phalaenoptilus nuttalli. Nine records. First record: M. A. Carriker, Jr., collected two eggs nearly ready to hatch on 23 July 1901 NW of Harrison, Sioux Co. (Carriker 1902). N. L. Ford collected a female with a soft-shelled egg in her oviduct on 8 July 1957 at the National Forest, Thomas Co. (Ford 1959). G. Hoge noted a nest with 2 eggs on 27 May 1963 near Powell, Jefferson Co. (Hoge 1964). D. B. Gates reported a nest with 2 eggs on 9 June 1974 at Chadron, Dawes Co. (CNRCP, \#13). D. Gersib reported a nest with 2 eggs found in mid-May 1976 at Branched Oak WMA, Lancaster Co. (Editor 1977b). R. A. Lock noted a nest with 2 eggs on 11 June 1976 at Crawford, Dawes Co. (NGPC archives). Rare regular breeder, scattered widely across western three- quarters of the state. Nests on bare ground or rocky outcrops, in grassland or in the edge of conifer woodlands. Nine egg dates: 15 May - 14 August. Nests with young reported 15 May - 14 August. All clutches and broods were of two eggs or young. Two clutches annually seem likely.

Chuck-will's-widow, Antrostomus carolinensis. Two records. J. Weaver found a nest with two eggs 4 June 1983 near Linwood, Saunders Co. (Lingle 1983). M. Brogie photographed a nest with 1 chick on 6 June 2012 at ICSP, Richardson Co. (Silcock 2012b). Extremely rare, probably regular breeder. The two ground nests reported were in dry upland oak woodlands.Eight egg dates, 4 - 11 June. Nests with young reported 6 - 16 June. One clutch of two eggs, and later with two young, has been recorded.

Eastern Whip-poor-will, Antrostomus vociferus. Five records. First record: M. A. Carriker, Jr., collected a nest with two eggs in Otoe Co. on 21 May 1897 (UNSM Cat. \#ZM08490). J. M. Nissen reported a nest with 2 eggs at Pawnee Prairie, near Burchard, Pawnee Co. on 22 - 31 May 1973 (CNRCP). On 16 May 2009 E. Paseka found a nest with 2 eggs at Ponca State Park, Dixon Co. (Silcock 2009a.). K. Lang reported nest with an egg and a chick at ICSP, Richardson Co. on 3 July 2014 (Silcock 2014a). Extremely rare regular breeder along the Missouri and lower Niobrara river valleys and a few other locations. Five nests 
reported, on ground, usually in woodland. Fourteen egg dates: 16 May - 3 July (16 - 31 May = 93\%). Clutch sizes reported: 5, usually 2 eggs, sometimes 1, mean 1.8, mode 2 .

\section{Family Apodidae (Swifts)}

Chimney Swift, Chaetura pelagica. Six records. First record: I. S. Trostler found a nest with five eggs in a hollow basswood snag on 8 June 1897 near Bellevue, Sarpy Co. (Trostler 1901). A. M. Brooking noted a nest with 2 eggs in May 1910 at Trumbull, Clay Co. (HM, Cat. \#02235). A. Eigsti noted a nest with 4 eggs on 21 June 1947 in his chimney at Hastings, Adams Co. (Eigsti 1947). Mrs. L. Seabury reported a nest with 4 eggs which failed, followed by a successful second attempt with 5 eggs in 1955 at Plainview, Antelope Co. (Editor 1956a). I found a nest with 5 eggs on 6 June 2007 S of Maxwell, Lincoln Co. (Mollhoff 2008). Common breeder in the east, but in limited numbers in the Sandhills and Panhandle. Nests are usually in chimneys but a few reports are from hollow trees or attached to walls inside unused buildings. Usually a solitary nester, but there is a report of twenty nests with a total of sixty young, found in an old school in Hooper, Dodge Co. (Stipsky 1930). Five egg dates: 6 - 28 June. Clutch sizes reported: 6, usually 4 - 5 eggs, sometimes 2 , mean 4.7, mode 5 .

White-throated Swift, Aeronuates saxatalis. Eight records. First record: M. A. Carriker, Jr., collected a nest with four eggs on 30 May 1901 in Monroe Canyon, Sioux Co. (UNSM, Cat. \#ZM08505). He collected 2 eggs there on 8 June 1901 (UNSM, Cat. \#ZM08506), 4 eggs from there on 12 June 1901 (UNSM, Cat. \#ZM08507), and 3 more eggs on 12 June 1901 (UNSM, Cat. \#ZM08508). I found an accessible nest in West Ash Creek canyon with 5 eggs on 12 June 1999 and 6 eggs on 2 June 2000 (Mollhoff 2001b). Rare breeder that nests among the cliffs in the Panhandle. Eight nests with twenty-three egg dates: 30 May - 25 June, with no notable clustering of dates. Clutch sizes reported: 8 , usually 3 - 4 eggs, sometimes $1-6$, mean 3.3 , mode 4 .

\section{Family Trochilidae (Hummingbirds)}

Ruby-throated Hummingbird, Archilochus colubris. Eight records. First record: E. Van Sant collected a nest with two eggs on 5 June 1898 at Albright, Douglas Co. (UNSM, Cat. \#ZM08512). R. Mullen took 2 eggs on 15 June 1900 at Child's Point, Sarpy Co. (UNSM archives). F. H. Shoemaker photographed a nest with 2 eggs on 19 August 1900 near Bellevue, Sarpy Co. (Shoemaker 1901). R. C. Green reported a nest with 2 eggs on 6 June 1976 at Bellevue, Sarpy Co. (CNRCP, \#179). J. A. Gubanyi noted a nest with 1 egg on 22 May 2012 at Seward, Seward Co. (Joseph Gubanyi, pers. comm.). J. Paseka reported a nest with 1 egg on 30 July 2015 at Omaha, Douglas Co. (Silcock 2015b). D. Zavadil reported a nest with 2 eggs on 19 July 2017 at Lindy, Knox Co. (Silcock 2017). Rare regular breeder along the Missouri and lower Niobrara rivers, as well as along other streams west to Stanton, Platte, and Jefferson counties. Nests reported 4 - $20 \mathrm{ft}$ (1.5 - 6 $\mathrm{m})$ high on branches. Nine egg dates: 22 May - 26 August. Clutch sizes reported: 8, usually 2 eggs, sometimes 1, mean 1.6, mode 2 .

Broad-tailed Hummingbird, Selasphorus platycercus. Two reports, but no documented nests. While camped at Glen, Sioux Co. 18 - 22 August 1905 a pair was seen daily, leading the observer to feel "...quite sure they bred." (Swenk 1906). For the second consecutive 
year a pair was noted in late June - early July 2008 near Gering, Scotts Bluff Co., but no further evidence of breeding was noted (Silcock 2008b). Any such observations should be investigated for evidence of breeding.

\section{Family Rallidae (Rails, Moorhens, Coots)}

Yellow Rail, Coturnicops noveboracensis. Three reports within the expected June egg-laying season, two of which were of birds flushed in nesting habitat, although no nests were located. The nearest known nesting areas are near the Canadian border in Montana and Minnesota. The preferred nest sites are in sedges and grasses near shallow marshes. Species that are found nesting with them include: Savannah Sparrow, Sedge Wren, Bobolink, Sora, Sandhill Crane, Red-winged Blackbird, and Wilson's Snipe (Bookhout 1995). All those species occur in extensive areas of that habitat in the Sandhills. When the elusive species is found there during the nesting season, a search for evidence of nesting should be made.

Black Rail, Laterallus jamaicensis. Eight reports. There is one record suggestive of breeding. W. C. Smith of Long Pine received a request from M.H. Swenk in 1913 for a list of sightings from his area. The list of 151 species Smith reported included a Black Rail nest with eggs in July 1899 in Brown Co. When Swenk asked if he had any further information on the Black Rail, Smith replied: "The Black Rail was not taken as a specimen because nest contained eggs already hatching and was identified by observation only, but while I think I am right, there may of course be a mistake, and as my records are not very extensive have to depend some on memory." (Smith 1913). Keep in mind that both Smith and Swenk were specimen collectors and without a specimen as evidence, it was not added to Swenk's periodic updates to the state list (Swenk 1915, 1918, 1920). As a bit of background, Smith was introduced to the NOU in a report by J. M. Bates at its first meeting in 1899 (Bates 1900). As a youngster, during 1893 - 1899, Smith had made a collection of eggs from 59 species in the area, which included both Sora and Virginia Rail eggs (SBM). I examined the collection and found only a single questionable identification. A set marked "Solitary Tattler" (Solitary Sandpiper) has measurements that exactly match Spotted Sandpiper, but are a bit small for the former. He also prepared study skins and taxidermy mounts, and after bird protection laws were put in place, he had a scientific collecting permit.

The other reports are of calling birds during the expected breeding season, 15 May - 31 July. The species is notoriously difficult to detect, let alone find a nest. There is still much to learn about its breeding distribution and basic biology (Eddleman et al. 1994).

King Rail, Rallus elegans. Five records. First record: I. S. Trostler collected a set of 7 eggs in East Omaha, Douglas Co. on 5 July 1897 (HSU, Cat. \#2450). F. H. Shoemaker took a picture (\#A147) of a nest with 10 eggs at Cutoff (now Carter) Lake on 7 July 1901 (Shoemaker undated). J. T. Zimmer collected a set of 7 eggs near Waverly, Lancaster, Co., on 30 May 1910 (Zimmer undated). S. and A. Callaway noted an adult with 5 or 6 young near Fairbury, Jefferson Co. on 29 July 1940 (Callaway and Callaway1940). Sporadic breeder in marshes, most reports are from eastern Nebraska. Nests are placed over water in emergent vegetation. Three egg dates: 30 May - 7 July. Three clutches, of 
7,7 , and 10 eggs, have been reported. Any breeding season birds should be investigated for evidence of breeding.

Virginia Rail, Rallus limicola. Fifteen records. First record: W. C. Smith collected two eggs on 20 May 1897 near Long Pine, Brown Co. (SBM, Cat. \#52). F. H. Shoemaker noted two nests, with 7 \& 9 eggs, on 29 May 1903 near Trout Lake, Cherry Co., photographed a nest there with 8 eggs on 30 May, and noted two more nests there, with 5 \& 8 eggs, on 5 June 1903. He noted a nest with 7 eggs on 15 July 1911 at Hackberry Lake, Cherry Co.

(Shoemaker undated). V. Young took a nest on 9 June 1923 at Simeon, Cherry Co. (UKBI, Cat. \# 74186). R. S. Sharpe reported a nest with 9 eggs on 3 June 1966 at CLNWR, Garden Co. (CNRCP, \#7). L. C. Holcomb noted a nest with 9 eggs on 25 May 1968 at Waterloo, Douglas Co. (CNRCP, \#41). Rare regular nester in marshes almost statewide. Nests placed in grass or emergent vegetation, often over water. Nineteen egg dates: 14 May - 15 July ( 20 May - 9 June $=84 \%$ ). Clutch sizes reported: 15, usually $7-9$ eggs, sometimes $4-5$, mean 7.3 , mode 7 .

Sora, Porzana carolina. Thirteen records. First record: L. Bruner collected a nest with 9 eggs near West Point, Cuming Co. on 30 May 1887 (UKBI, Cat. \#95592). J. A. Dickinson took 10 eggs on 31 May 1896 near Gresham, York Co. (WFVZ, Cat. \#205953). W. Tout noted two nests, with 14 \& 18 eggs on 13 June 1896 (Tout 1901). J. L. Childs took 10 eggs on 29 May 1908 near Thedford, Thomas Co. (Childs 1908). A. M. Brooking took 11 eggs on 17 June 1917 at Inland, Clay Co. (HM, Cat. \#02208). W. W. Lemburg recorded a nesting cycle, from eggs through fledging, at Cairo, Howard Co. (Lemburg 2012). Rare regular breeder in marshes nearly statewide. Ten nests reported were all built over water. Sixteen egg dates: 15 May - 31 July (15 May - 13 June $=88 \%$ ). Clutch sizes reported: 13 , usually 7 - 11 eggs, mean 10.0, mode 10.

Common Gallinule, Gallinula galeata. Eight records. First record: L. Skow collected a nest with 9 eggs at Cutoff Lake, Douglas Co. on 20 June 1893 (UKBI, Cat. \#95599). I. S. Trostler and G. W. Sabine took 9 eggs on 9 July 1893 near Cut-off Lake, Douglas Co. (WFVZ, Cat. \#92396). R. Mullen took 6 eggs on 4 July 1897 at Cut Off Lake, Douglas Co. (UNSM, Cat. \#ZM08236). W. C. Garthright noted 10 eggs on 7 July 1984 at Lincoln, Lancaster Co. and another nest there with 11 eggs on 23 June 1985 (CNRCP). Garthright also noted a nest with 9 eggs on 16 May, and another with 9 eggs on 16 June 1985 at a second site at Lincoln, Lancaster Co. (Wm. Garthright, pers. comm.). Sporadic breeder, with a single report from Dakota Co.; all other reports are from SE part of state. Nests usually placed in rushes or cattails over water, but one nest reported in willows above water. Eleven egg dates: 16 May - 11 July, with no date clusters. Clutch sizes reported: 8, usually 9 - 10 eggs, sometimes 6 -11, mean 9.0, mode 9 .

American Coot, Fulica americana. One hundred fifty-nine records. First record: On 20 June 1893 L. Skow collected a set of 8 eggs at Cutoff Lake, Douglas Co. (UKBI, Cat. \#95598). W. Tout noted a nest with 14 eggs on 8 June 1896 near York, York Co. (Tout 1901). I. S. Trostler took 11 eggs on 14 July 1897 at Omaha, Douglas Co. (WFVZ, Cat. \#163595). J. S. Hunter took 11 eggs on 4 June 1900 at Trout Lake, Cherry Co. (UNSM, Cat. \#ZM08240). H. C. Oberholser noted a nest with 10 eggs on 12 June 1915 at Sweetwater Lake, Cherry Co. (Oberholser and McAtee 1920). L. M. Gates noted two nests, each with 7 eggs, on 23 June 1915 near Mitchell, Scotts Bluff Co. (Gates undated). P. H. Young took 10 eggs on 
16 June 1923 at Simeon, Cherry Co. (UKBI, Cat. \#2017). W. T. Krummes noted a nest 21 eggs on16 June 1933 at CLNWR, Garden Co. (CLNWR archives). Common breeder, often colonial, on ponds and marshes statewide. Builds floating nest in emergent rushes and cattails. One hundred ninety-two egg dates: 5 May - 26 July (28 May - 23 June $=79 \%$ ). Clutch sizes reported: 159, usually 5 - 10 eggs, sometimes 1 - 21, mean 7.2, mode 7.

\section{Family Gruidae (Cranes)}

Sandhill Crane, Antigone canadensis. Forty-one reports, one record. First record: F. C. Carpenter collected a set of 2 eggs on 14 May 1883 at Ft. Niobrara, Cherry Co. (USNMNH, Cat. \#B43065). L. Bruner found 3 broods in SW Holt Co. in 1883 (Bruner 1902). F. W. Tate took 2 eggs in 1904 on Goose Ck., probably in Cherry Co. (HM, Cat. \#28426). On 20 August 1994 J. G. Jorgensen found a pair with 2 young in Clay Co.(Silcock and Rosche 1994a). Now a rare regular breeder in large marshes in Sandhills, along North Platte River, lower Niobrara River, and Rainwater Basin. Pairs build platform nest in heavy growth of cattails, and seem to have high site fidelity. One historic egg date, 14 May 1883. Adults with young noted as early as 15 April. Twenty-five brood sizes reported: usually 2 young, sometimes $1-3$, mean 1.8 , mode 2 .

\section{Family Recurvirostridae (Stilts, Avocets)}

Black-necked Stilt, Himantopus mexicanus. Twenty-three records. First record: M. J. Helsinger found a pair of adults with young at Lower Harrison Lake and a second pair with young at Martin Lake, CLNWR, Garden Co. on 11 July 1985 (Helsinger 1985a). I found two nests, each with 1 egg, on 4 June 1987 near Lakeside, Sheridan Co. J. Farrar found two nests, each with 4 eggs on 16 May, another with 4 eggs on 3 June, another with 4 eggs on 4 June, and another with 4 eggs on 6 June 2000 near Lakeside, Sheridan Co. (Jon Farrar, pers. comm.). Rare regular breeder, it was initially found only in the western Sandhills. It later spread to the Rainwater Basin, and more recently a pair nested in Dakota Co. after severe flooding there. Nests built on bare or grassy shoreline near ponds, sometimes built up higher to stay above rising water levels. Thirty-two egg dates: 16 May - 5 July (23 May - 11 June $=69 \%$ ). Clutch sizes reported: 23, usually 4 eggs, sometimes 1 - 3, mean 3.2, mode 4.

American Avocet, Recurvirostra americana. Two hundred two records. First record: C. A. Black and A. M. Brooking found a nest with just-hatched young at Crescent Lake (now CLNWR), Garden Co. on 18 June 1917 (Swenk undated). C. A. Black and A. M. Brooking noted 3 eggs on 23 June 1917 at Crescent Lake, Garden Co. (Swenk undated). W. T. Krummes noted two nests, with 2 \& 3 eggs, on 4 June 1933 atCLNWR, Garden Co. (CLNWR archives). R. H. Brashears reported two nests, each with 4 eggs, on 5 June 1936 near Ellsworth, Sheridan Co. (CNRCP, \#274, \#283). R. S. Sharpe noted a nest with 4 eggs on 13 June 1965 at CLNWR, Garden Co. (CNRCP, \#1). M. M. Tremaine reported a nest with 4 eggs on 25 May 1972 near Oshkosh, Sheridan Co. (CNRCP, \#250). Rare regular breeder, primarily in areas of alkaline lakes and ponds in the Panhandle and adjacent Sandhills. It also breeds in Rainwater Basin when adequate water is present. Nest built on bare shoreline or nearby grass. Nest sometimes built up to keep eggs above rising water levels. Usually a colonial nester, with colonies of 5 - 50 pairs reported. Two 
hundred sixty-eight egg dates: 15 May - 14 July (23 May - 15 June $=82 \%$ ). Clutches reported: 202, usually 4 eggs, sometimes $1-5$, mean 3.4, mode 4 .

\section{Family Charadriidae (Plovers)}

Killdeer, Charidrius vociferus. Sixty-three records. First record: M. Pew collected 3 eggs from a nest near Hebron, Thayer Co., on 6 June 1890 (YPM, Cat. \#ORN146066). L. Bruner took 4 eggs on 28 June 1901 near Swan Lake, Holt Co. (Bruner undated). J. T. Zimmer took 4 eggs 12 June 1910 at Ceresco, Saunders Co. (Zimmer undated). A. M. Brooking took 4 eggs on 20 April 1916 at Inland, Clay Co. (HM, Cat. \#02315). H. Harris took 3 eggs on 26 May 1922 at Simeon, Cherry Co. (UKBI, Cat. \#74208). H. Harris took 4 eggs on 23 May 1923 at Simeon, Cherry Co. (USNMNH, Cat. \#B40335). Regular, abundant breeder statewide. Nest is a shallow scrape on bare ground, often near water. One hundred thirty-one egg dates: 14 April - 13 July (11 May - 17 June =81\%). Clutch sizes reported: 63, usually 4 eggs, sometimes $1-5$, mean 3.6, mode 4 .

Piping Plover, Charadrius melodus. Three hundred twenty-two records. First record: G. P. Anderson noted a nest with 2 eggs on 13 May 1900 at Dannebrog, Howard Co. (Anderson 1900). He later took 3 eggs there on 20 May 1900 (WFVZ, Cat. \#204915). M. H. Swenk noted a nest with 3 eggs on 24 June 1902 on the Niobrara River north of Long Pine, Brown Co. (Swenk 1902a). G. Pickwell noted a nest with 4 eggs on 20 May 1922 on the beach at Capitol Lake, Lancaster Co. (Pickwell 1925). R. A. Moser noted a nest with 4 eggs on 12 June 1940 at Carter Lake, Douglas Co. (Moser 1940). Mrs. L. D. Heineman noted a nest with 4 eggs on 3 July 1943 at Plattsmouth, Cass Co. (Heineman 1944). R. G. Cortelyou reported a nest with 4 eggs on 11 June 1966 at DeSoto Bend NWR, Washington Co. (CNRCP, \#15). Rare breeder, on Tier I / Endangered Species lists, but declining despite research and special protections. Dependent on shifting sandbars on our shallow rivers, as well as sand spoil piles at gravel mining operations along the rivers. Initiation of nesting, and re-nesting, is highly dependent on adequate river flow, but may be endangered by sudden heavy rains. Three hundred sixty-five egg dates: 6 May -28 July ( 3 June -8 July $=65 \%$ ). Clutch sizes reported: 322 , usually $3-4$ eggs, sometimes 1 - 5, mean 3.6, mode 4 .

Mountain Plover, Charadrius montanus. Two hundred ninety records. First record: George Suckley collected four eggs on 13 July 1859 from a nest "...Platte River, North Fork, ca. 120 miles W of Kearney" (USNMNH, Cat. \#B2858). R. A. Lock found an adult with a halfgrown young on 7 June 1975 near Bushnell, Kimball Co. (Lock 1975). M. K. Clausen noted a nest with 3 eggs on 21 May 1990 near Bushnell, Kimball Co. (Clausen 1990). S. J. Dinsmore noted a nest with 3 eggs on 18 May 1997 near Kimball, Kimball Co. (NGPC archives). Dinsmore noted a nest with 3 eggs on 17 May 1999 near Kimball, Kimball Co. (NGPC archives). Localized rare, regular breeder, Tier I species. Nests on bare ground in short-grass prairie or fallow fields in Kimball Co. in the SW Panhandle. Four hundred thirty egg dates: 15 April - 20 July (10 May - 16 June =78\%). Clutch sizes reported: 290, usually 3 eggs, sometimes $1-4$, mean 2.8 , mode 3 .

Snowy Plover, Charadrius nivosus. Thirteen records. First record: On 10 June 1998 G. A. Pavelka found a pair with a nest and 3 eggs on a Missouri River sandbar near Santee, Knox Co. (Mollhoff 2001b). S. J. Dinsmore noted a nest with 3 eggs on 12 May 2004 at Harlan 
County Reservoir, Harlan Co. (Silcock 2004). G. Wilson recorded 5 nests with 1 - 3 eggs, as well as a nest with 3 eggs and 2 young, in 2006 at Lake McConaughy, Keith Co. (Gabriel Wilson, pers. comm.). M. Tacha noted two nests, with 3 \& 4 eggs, on 21 June 2007 near Gibbon, Buffalo Co. (Martha Tacha, pers. comm.). Extremely rare but increasing, may become a regular breeder in years when adequate sandbar nesting habitat is available. Sixteen egg dates: 12 May - 21 June, no date clusters noted. Clutch sizes reported: 13: usually 3 eggs, sometimes 1 - 5, mean 3.1, mode 3.

\section{Family Scolopacidae (Sandpipers)}

Upland Sandpiper, Bartramia longicauda. One hundred sixty-four records. First record: Two eggs were collected from a nest at Ft. Kearney, Kearney Co. on 26 June 1859 by George Suckley (USNMNH, Cat. \#B2179). A. Hall took 4 eggs on 23 May 1880 in the Platte River Valley, Hall Co. (WFVZ, Cat. \#157076). W. C. Smith took 2 eggs on 12 June 1898 near Long Pine, Brown Co. (SBM, Cat. \#56). M. A. Carriker, Jr., took 4 eggs on 3 June 1901 above Warbonnet Canyon, Sioux Co. (UNSM, Cat. \#ZM08257). H. Harris took 3 eggs on 27 May 1923 at Simeon, Cherry Co. (USNMNH, Cat. \#B40333). H. J. Turner noted 4 eggs 12 May 1964 at Holstein, Adams Co. (CNRCP, \#4). Abundant breeder state-wide. Places its ground nests in a wide variety of grasslands. Recently it has begun taking advantage of the crop stubble in minimum-till farm fields in the spring, nesting before the new crop emerges. Three hundred three egg dates: 11 April - 15 July (18 May - 18 June $=86 \%$ ). Clutch sizes reported: 164, usually 4 eggs, sometimes $1-5$, mean 3.7, mode 4 . Brown-headed Cowbird parasitized $0.6 \%$ of nests, no doubt unsuccessfully.

Long-billed Curlew, Numenius americanus. Thirty-six records. First record: On the Stephen Long Expedition of 1819-20, Thomas Say found adults with young on 8 June 1820 between Shell Creek and the Loup River in SE Platte Co. (James 1972). H. Spink took a nest with 4 eggs in May 1887 in Pierce Co. (FMNH, Cat. \#1198). W. C. Smith took 1 egg on 3 June 1898 near Long Pine, Brown Co. (SBM, Cat. \#54). G. Spencer took 1 egg on 13 May 1912 near Alliance, Box Butte Co. (HM, Cat. \#10783). W. T. Krummes noted 4 eggs on 5 June 1933 at CLNWR, Garden Co. (CLNWR archives). R. H. Brashears noted 4 eggs on11 May 1937 near Ellsworth, Sheridan Co. (CNRCP, \#51). R. J. Witschy photographed 4 just-hatched young on 30 May 1965 in Banner Co. (CNRCP, \#1). Uncommon to rare breeder in large open expanses of mixed-grass and shortgrass prairie. Seventy-seven egg dates: 1 May - 16 June, no date clusters noted. Clutch sizes reported: 33, usually 4 eggs, sometimes 2 - 3, mean 3.6, mode 4.

Marbled Godwit, Limosa fedoa. Five records. First record: Thomas Say found adults with young between Shell Creek and the Loup River in what is now Platte Co. on 8 June 1820 (James 1972). In 1990, R. C. Rosche reportedly saw adults vigorously defending 2 downy young (Editor 1990). S. R. Jones observed a pair near Diamond Lake, Sheridan Co. in a vigorous defensive display (Stephen Jones, pers. comm.). On 16 June 2005 C. C. Kerns found a nest with 3 eggs in Sheridan Co. (Mollhoff 2005b, Silcock 2005b). On 17 June 2006 J. E. Ducey reported a pair with fledglings in southern Sheridan Co. (Silcock 2006). Probably an extremely rare breeder in large expanses of grassland. Following the homestead era, it was probably extirpated shortly after 1900 but has recently begun to 
re-occupy its former range. There is a single record of nest with four eggs on 16 June 2005 (Mollhoff 2005b). Adults with dependent young have been reported 8 - 20 June.

American Woodcock, Scolopax minor. Six records. First nest record: There is a late report by R. Mann of a nest with $1 \mathrm{egg}$, "... probably in the last half of May 1973..." (but the date may be questionable since other reports are in March and April) at the Gifford Peninsula, Sarpy Co. (Editor 1974a). J. J. Dinan found two nests, each with 4 eggs, $10 \mathrm{mi}$. W of Lincoln, Lancaster Co., on 22 March 1983 (CNRCP). W. T. White noted a nest with 4 eggs on 7 April 1985 near Hickman, Lancaster Co. (CNRCP). D. A. Wolff noted a nest with 3 eggs on 20 March 1988 near Wood Duck WMA, Stanton Co. (Duane Wolff, pers. comm.) Rare regular breeder in eastern half of state, places nests on the ground, in vegetation, often near water or in bogs. Four egg dates: 20 March - 7 April (20 - 22 March $=75 \%)$. Clutch sizes reported: 5 , usually 4 eggs, sometimes 1 - 3, mean 3.2, mode 4.

Wilson's Snipe, Gallinago delicata. Eleven records. First record: C. A. Black found a nest with 4 eggs in June 1915 in a bog near Shafer Lake, Garden Co. (Swenk 1918, Black 1920). K. J. Brennan noted a nest with 4 eggs in late May 1983 at CLNWR, Garden Co. (Helsinger 1985c). J. J. Dinan noted a nest with 4 eggs on 28 April 1984 at Jack Sinn WMA, Lancaster Co. (NGPC archives). C. Lesiak noted a nest with 4 eggs on 6 May 1986 at Jack Sinn WMA, Lancaster Co. (NGPC archives). G. A. Steinauer noted a nest with 4 eggs on 2 May 1989 near Merritt Reservoir SRA, Cherry Co. (NGPC archives). L. Blake noted a nest with 4 eggs on 21 June 1993 near Chambers, Holt Co. (Silcock and Rosche 1994b). L. Kizer noted a nest with 4 eggs on 20 April 2011 NW of Ericson, Garfield Co. (Lanny Kizer, pers. comm.). Uncommon regular breeder in the Sandhills, with scattered reports from areas of acceptable habitat elsewhere. Nests placed on the ground in wet meadows and boggy areas. Nine egg dates: 28 April - 24 June, no date clusters noted. Clutch sizes reported: 11 , usually 4 eggs, rarely 1 , mean 3.7, mode 4.

Spotted Sandpiper, Actitis macularius. Eleven records. First record: J. C. Crawford, Jr., took 4 eggs on 30 May 1898 at West Point, Cuming Co. (UNSM, Cat. \#ZM08261). G. P. Anderson took 4 eggs on 27 June 1900 at Dannebrog, Howard Co. (WFVZ, Cat. \#209002). J. T. Zimmer took 4 eggs on 13 June 1912 at the National Forest, Thomas Co. (Zimmer undated). W. Tout noted a nest with 4 eggs on 13 June 1931 at North Platte, Lincoln Co. (Tout 1947). C. W. Schafer noted a nest with 4 eggs on 27 May 1974 near Wood River, Hall Co. (CNRCP, \#252). W. W. Lemburg noted a nest with 4 eggs on 1 June 1987 near Cairo, Howard Co. (Wm. Lemburg, pers. comm.). Common regular breeder along streams statewide. Places its nests near water, on sandbars, in grass or other vegetation. Twenty-two egg dates: 12 May - 27 June (24 May - 13 June = 86\%). Clutch sizes reported: 12 , usually 4 eggs, sometimes 2 - 3, mean 3.7, mode 4.

Solitary Sandpiper, Tringa solitaria. Four reports. No breeding records. The first three reports (Taylor 1888, Bruner 1901, Bruner et al. 1904) say "breeds," without presenting any evidence of breeding, and are based simply on the presence of the birds. At that time little information on the timing of fall migration dates was available. When a report listing migration dates became available, it showed that earlier reports of young birds fell clearly into the fall migration period (Cooke 1910). Later, researchers concluded 
"That the Solitary Sandpiper breeds in Nebraska can not at this time be considered as established knowledge." (Swenk and Fichter 1942).

The fourth report concerns two eggs collected on 1 June 1897 by W. C Smith near Long Pine, Brown Co. and currently in a museum in Ainsworth (\#34, SBM). The set is labeled Solitary Tattler (=Solitary Sandpiper). My measurements and study concluded they were instead Spotted Sandpiper (Actitis macularius) eggs not as heavily marked/spotted as is typical of Spotted Sandpiper eggs.

Lesser Yellowlegs, Tringa flavipes. Three reports. No breeding records. The first credits J. M. Bates's statement "Cherry county - breeds...", even though no specific details are mentioned (Bruner 1896). The remaining two reports are of adults with three and four young in Sheridan Co, by a reliable observer who reported a wide variety of waterfowl and shorebirds (Keller 1931a, 1931b). While none of his other reports seemed questionable, oddly enough he did not report Upland Sandpiper, which should have been abundant in his area. Given that this species nests only in the northern taiga forests, it seems likely that he misidentified the somewhat similar Upland Sandpiper.

Willet, Tringa semipalmata. Twenty-eight records. First record: On 17 May 1933 W. T. Krummes found a completed clutch of 4 eggs, which had been laid one egg per day, near Crane Lake, CLNWR, Garden Co. (CLNWR). R. H. Imler took 1 egg on 22 May 1940 in Garden Co. (WFVZ, Cat. \#188521). M. M. Tremaine noted 3 eggs on 24 May 1972 near Oshkosh, Garden Co. (CNRCP, \#150). R. H. Brashears noted 3 eggs on 1 June 1973 at CLNWR, Garden Co. (CNRCP, \#155). M. French noted 4 eggs on 17 May 2003 at Perrin Lake, CLNWR, and another nest with 4 eggs on 24 May 2008 at South Boyd Lake, CLNWR, Garden Co. (Marlin French, pers. comm.). Rare breeder, limited to the open mixed-grass prairies of the Sandhills and sparingly in adjacent shortgrass grasslands. Ground nests may be placed in dry uplands or in low wet meadows. Fifty-four egg dates: 9 May - 25 June (16 May - 7 June $=83 \%$ ). Clutch sizes reported: 28 , usually 4 eggs, sometimes 1 - 3, mean 3.4, mode 4 .

Greater Yellowlegs, Tringa melanoleuca. Three reports. No breeding records. Two of the reports listed (Bruner 1896, 1901), give no documentation. They seem refer to another report (Bruner 1902) in which the author mentioned seeing the birds in Holt Co. on a trip in late June - early July, a time when we expect the post-breeding migrants to be coming through (Cooke 1910, Sharpe et al. 2001).

Wilson's Phalarope, Phalaropus tricolor. One hundred thirty-nine records. First record: C. A. Black collected a nest with 4 eggs in May 1913 at Crescent Lake, Garden Co. (UNSM Cat. \#ZM08252), and took another set of 4 eggs there on 20 June 1913 (HM, Cat. \#02646). H. Harris took 4 eggs on 23 May 1922 at Simeon, Cherry Co. (USNMNH, Cat. \#40328), and a second set of 4 eggs there on 25 May 1922 (WFVZ, Cat. \#3030). F. J. Keller noted 5 eggs on 6 June 1931 near Antioch, Sheridan Co. (Swenk 1931). L. L. Mohler noted a nest with 4 eggs on 9 June 1949 near Berea, Box Butte Co. (Mohler 1952). J. E. Wilbrecht noted a nest with 4 eggs on 6 June 1967 at CLNWR, Garden Co. (CNRCP, \#17). Uncommon regular breeder. The ground nests are usually placed in wet meadows near a water source. Two hundred thirty-two egg dates: 6 May - 3 July (22 May - 13 June $=79 \%)$. Clutch sizes reported: 139 , usually 4 eggs, sometimes $1-5$, mean 3.7 , mode 4 . 


\section{Family Laridae (Gulls, Terns)}

Franklin's Gull, Leucophaeus pipixcan. Six nest records. First record: R. S. Sharpe found 2 nests, each with 2 eggs, among a colony of about 30 pairs, on Smith Lake, CLNWR, Garden Co., on 9 June 1965 (Sharpe and Payne 1966). On 2 June 1966 Sharpe found 2 nests, each with 2 eggs, and on 9 June 1966 he again found 2 nests, each with 2 eggs, all of them at Smith Lake (CNRCP). Sporadic breeder, but has not been recorded since. The nests were built on floating wooden platforms or on floating mats of vegetation. Fourteen egg dates: 2 June - 11 June. Clutch sizes reported: 6, each with 2 eggs, mean 2.0, mode 2.

Ring-billed Gull, Larus delawarensis. Two reports. Both reports refer to a statement: "... Cherry county - breeds (J. M. Bates); ..." (Bruner 1896, 1901). No documentation is available to judge the validity of the report. It is not accepted.

Least Tern, Sternula antillarum. Three hundred three records. First record: On 20 June 1896 W. Tout collected 3 eggs at a rainwater basin 6 miles SW of York, York Co. (Tout 1901). Tout reported 17 nests with 1 - 4 eggs, on 6 July 1926 on the South Platte River, Lincoln Co. (Tout 1947). R. A. Moser made a detailed study of a 6-nest colony during June - July 1940 at Carter Lake, Douglas Co. (Moser 1940). G. A. Wingfield noted 11 nests, each with 3 eggs, on 21 June 1983 on the Niobrara River near Redbird Creek, Holt Co. (CNRCP). On 22 June 1983 Wingfield noted a 6-nest colony on the Niobrara River near Naper, Boyd Co. (CNRCP). J. J. Dinan noted a colony with 31 nests on 8 July 1983 on the Platte River near Memphis, Saunders Co. (CNRCP). Uncommon regular colonial breeder on major rivers across the state, colonies with 2 - 31 nests reported. Species is on Tier I / Endangered Species lists. Nests on riverine sandbars and sand spoil piles, competing for limited habitat with irrigators, recreational, and other river users, especially in dry years. Three hundred ninety-three egg dates: 21 May - 2 August (14 June - 13 July =77\%). Clutch sizes reported: 303, usually 2 - 3 eggs, sometimes 1 - 4, mean 2.3, mode 3.

Black Tern, Chlidonias niger. Sixty-six records. First record: L. Bruner collected 3 eggs on 5 June 1887 from a nest near West Point, Cuming Co. (UKBI, Cat. \#95625). J. A. Dickenson took 3 eggs on 14 June 1890 near Gresham, York Co. (YPM, Cat. \#ORN129337). I. S. Trostler took 3 eggs on 26 June 1895 on West [Cody] Lake, Cherry Co. (WFVZ, Cat. \#202809). W. Tout noted 3 eggs in each of three nests, on 20 June 1896 near York, York Co. (Tout 1901). J. S. Hunter took 2 eggs on 4 June 1900 at Trout Lake, Cherry Co. (UNSM, Cat. \#ZM08131). A. M. Brooking took 4 eggs on 11 June 1915 at Inland, Clay Co. (HM, Cat. \#02116). J. H. Sather noted 3 eggs on 31 May 1949 at VNWR, Cherry Co. (Sather undated). Uncommon regular, colonial breeder in marshes in the Sandhills, and irregular at low numbers elsewhere in the state when water conditions permit. Builds a tiny floating nest that keeps the eggs barely above water, or nests on the remains of muskrat lodges. Sixty-nine egg dates: 28 May - 19 July, (3 - 30 June $=64 \%)$, with a second cluster at 11 - 15 July $=26 \%)$. Clutch sizes reported: 66, usually 3 eggs, sometimes $1-4$, mean 2.5, mode 3.

Forster's Tern, Sterna forsteri. Forty-one records. First record: J. S. Hunter collected a set of 3 eggs, plus another set of 4 eggs, on 4 June 1900 from nests on Trout Lake, Cherry Co. (UNSM, Cat. \#ZM08113, \#ZM08114). F. H. Shoemaker noted 12 nests, each with 1 - 3 eggs, on 31 May 1903 on Hackberry Lake, Cherry Co. (Shoemaker undated). J. L. Childs took 1 egg on 21 May 1914 near Oshkosh, Garden Co. (FMNH, Cat. \#19051). M. Maryott 
took 3 eggs on 25 May 1915 at Crescent Lake, Garden Co. (HM, Cat. \#03867). J. H. Sather noted 3 eggs, on each of two nests, on 7 July 1951 at VNWR, Cherry Co. (Sather undated). R. S. Sharpe noted 3 eggs on 9 June 1965 at CLNWR, Garden Co. (CNRCP, \#2). Rare regular colonial breeder on marshy lakes in northern and western Sandhills. Colonies of 6 - 43 nests reported. Nests built on mats of floating vegetation or on muskrat lodges. Forty-six egg dates: 21 May - 20 July, no notable date clusters, but July dates may be re-nesting due to predation or storm damage. Clutch sizes reported: 41 , usually 3 eggs, rarely $1-4$, mean 2.8 , mode 3 .

\section{Family Phalacrocoracidae (Cormorants)}

Double-crested Cormorant, Phalacrocorax auritus. Three hundred ninety-five records. First record: F. M. Uhler found 20+ nests on 30 July 1930 in a mixed heron colony near Hyannis, Grant Co. (Lewis 1931). H. Benckeser noted five nests, each with 3 eggs, on 14 June 1948 at Lake McConaughy, Keith Co. (Collister 1948). R. S. Sharpe noted a nest with 3 eggs on 9 June 1965 at CLNWR, Garden Co. (CNRCP, \#2). R. H. Brashears noted ten nests, each with 3 eggs, on 30 May 1973 at CLNWR, Garden Co. (CNRCP). L. McDaniel noted a colony with 922 nests, with an average of 3 eggs apiece, on 7 July 1988 at VNWR, Cherry Co. (Len McDaniel, pers. comm.). Uncommon regular colonial breeder across the state on larger rivers and lakes. Colonies of 2 - 922 nests reported, frequently associated with heron colonies. Nests in trees placed $20-60 \mathrm{ft}(6-18 \mathrm{~m}) \mathrm{up}$, trampled into stands of cattails or phragmites, in goose nest tubs, on muskrat lodges, or floating mats of vegetation. One thousand one hundred nine egg dates: 9 April - 9 July (2 - 24 June $=97 \%$ ). Clutch sizes reported: 395, usually 4 eggs, sometimes 1 - 5, mean 3.7, mode 4.

\section{Family Pelicanidae (Pelicans)}

American White Pelican, Pelecanus erthrorhynchus. Seven reports. Two records. First record: As he was monitoring waterfowl nests, refuge manager L. McDaniel found birds on 10 nests on 24 May 1995 on a protected island in Marsh Lake, VNWR, Cherry Co. The birds flushed on his arrival. On his next visit on 29 May the site was empty. On 12 June he found 4 eggs randomly scattered at the site. Prior to this, he had found 'dumped' eggs on 25 May 1988 (2 eggs), 2 June 1991 (4 eggs), 17 May 1993 (4 eggs), (Len McDaniel, pers. comm.).

While monitoring duck brood counts at Marsh Lake, Cherry Co., on18 July 2019, VNWR biologist $\mathrm{M}$. Nenneman found 17 immature pelicans in ground nests, among a Doublecrested Cormorant colony (Melvin Nenneman, pers. comm.). This constitutes the only record of successful breeding in the state.

\section{Family Ardeidae (Bitterns, Herons, Egrets)}

American Bittern, Botaurus lentiginosus. Fifteen records. First record: N. S. Goss collected

3 eggs on 12 May 1885 from a nest near West Point, Cuming Co. (UKBI, Cat. \#95536). F. $\mathrm{H}$. Shoemaker noted a nest with 4 eggs on 30 May 1903 near Trout Lake, Cherry Co. (Shoemaker undated). C. A. Black took 4 eggs on 22 June 1918 at Shafer Lake, Garden Co. (HM, Cat. \#02645). R. H. Brashears noted 3 eggs on 22 June 1937 near Ellsworth, 
Sheridan Co. (CNRCP, \#72). J. E. Wilbrecht noted 4 eggs on 12 June 1967 at CLNWR, Garden Co. (CNRCP, \#23). L. McDaniel noted a nest with 3 of the 4 eggs just hatched on 9 July 1985 at VNWR, Cherry Co. (Len McDaniel, pers. comm.). P. Dunbar noted a nest with 6 eggs on 28 May 2007 at Harvard WPA, Clay Co. (Mollhoff 2008). Rare regular breeder, largely limited to the Sandhills and Rainwater Basin, but occasionally uses large marshes elsewhere. Nests in emergent vegetation over water, or on ground nearby. Twenty-two egg dates: 12 May - 28 June (2 - 23 June =77\%). Clutch sizes reported: 15 , usually 3 - 5 eggs, sometimes 1 - 6, mean 3.9, mode 4 .

Least Bittern, Ixobrychus exilis. Twenty-eight records. First record: On 29 May 1889 G. A. Coleman found a nest with 3 eggs in "the swamp north of Peru," Nemaha Co. (Coleman undated). L. Skow took 6 eggs on 21 May 1893 at Hardwood Lake, Omaha, Douglas Co. (UKBI, Cat. \#95542). I. S. Trostler took 5 eggs on 11 June 1893 at Cut Off Lake, Douglas Co. (WFVZ, Cat. \#205074). G. W. Morse took 4 eggs on 3 July 1893 at Cut-off Lake, Douglas Co. (NYSM, Cat. \#ZO-11490). A. C. Griffin took 3 eggs on 4 July 1897 at Cutoff Lake, Douglas Co. (UNSM, Cat. \#ZM08186). D. P. Wallace took 4 eggs on 8 June 1898 at Cutoff Lake, Douglas Co. (MVZ, Cat. \#1132). Rare regular breeder, mostly in eastern half. Nests in marshes of any size, usually placed in emergent vegetation over water; however, one nest was discovered by the noise made by an adult trying to drive a fox squirrel, Sciurus niger, away from its nest, $20 \mathrm{ft}(6 \mathrm{~m})$ up on a branch of an apple tree (Ludlow 1930). Thirty-five egg dates: 21 May - 23 July, no notable date clusters, but 4 June -7 July $=77 \%$. Clutch sizes reported: 28 , usually $3-5$ eggs, sometimes $1-6$, mean 4.1, mode 4.

Great Blue Heron, Ardea herodias. Fifty-two records. First record: L. Skow collected a set of 3 well-incubated eggs on 13 May 1894 at Bouyer's Island, Douglas Co. (UKBI, Cat. \#95535). L. Bruner took 5 eggs on 22 April 1905 in the Forest Reserve, Thomas Co. (UNSM, Cat. \#ZM08189). J. T. Zimmer took 5 eggs on 19 May 1912 at the Forest Reserve, Thomas Co. (Zimmer undated). L. Blus noted sixteen nests on 13 June 1966 with 1 - 4 eggs, at the Nebraska National Forest, Thomas Co. (CNRCP). C. L. Cink noted a nest with 4 eggs and fourteen other nests with 3 - 4 young on 12 June 1971 at Swanson Reservoir, Hitchcock Co. (Cink 1972). Abundant regular colonial breeder statewide, nesting beside lakes and rivers, sometimes miles from water. Nests usually placed high in trees, often 40 - $100 \mathrm{ft}(12-30 \mathrm{~m})$ up, but also nests in cattails. Forty-six reports of colonies, with 2 - 100+ nesting pairs. Colonies sometimes include other herons, cormorants, ibis, and Red-tailed Hawk nests, or Turkey Vulture roosts. Colonies may persist in same location for a decade or more, or may re-locate after several years. Thirteen egg dates: 22 April - 13 June, no date clusters noted. Clutch sizes reported: 52, usually 4 eggs, sometimes 1 - 5, mean 4.0, mode 4.

Great Egret, Ardea alba. Two reports. First report: R. G. Cortelyou relayed a report "...that a pair (or more) of American Egrets are nesting with the Great Blue Herons on the Gifford Farm, east of Fontenelle Forest." (Cortelyou 1960). The second report, also from Sarpy Co., near La Platte, where about seven adults were building nests in a Great Blue Heron colony on 18 June 2008 (Silcock 2008b). On 12 July 2008 I checked the site while surveying the block for NBBAP II, and observed 2 - 3 pairs on their nests (Mollhoff 2016). Sporadic breeder, nests usually inaccessible due to height. 
Snowy Egret, Egretta thula. Two records. First record: A well-grown young bird was photographed on the nest by a staff biologist at CLNWR, Garden Co., in June 1989 (Gordon Warrick, pers. comm.). A report from Lancaster Co., in June 1895 (Eiche 1901), has been questioned and recently shown to be a case of mistaken identity. [See Little Blue Heron account below]. A pair apparently on territory at Mormon Island Crane Meadows, Hall Co. in 1985, was later seen with young (Gary Lingle, pers. comm.). Sporadic breeder. Breeding colonies have been established in SE South Dakota (Tallman et al. 2002), SE Wyoming (Faulkner 2010), and north of Denver in Colorado (Wickersham 2016).

Little Blue Heron, Egretta caerulea. One record. An incubating female was shot and its nest and eggs destroyed, on Oak Creek about 3 mi. NW of Lincoln in 1895 (Eiche 1901). Since it was still in all-white Definitive Basic (juvenile) plumage, which it sometimes wears into its first breeding (Palmer 1962), it was initially misidentified as a Snowy Egret and there were questions and confusion about the record (Sharpe et al. 2001). Recent discovery of records transferring the Eiche collection to UNSM clarified the record (Thomas Labedz, pers. comm).

Cattle Egret, Bubulcus ibis. Nine records. First record: Following the first nesting by one pair at VNWR in 1982 (Len McDaniel, pers. comm.), D. Emrick noted four nests, each with 4 eggs, plus a fifth nest with 5 eggs, on 22 June 1984 on Middle Marsh Lake, Cherry Co., (Don Emrick, pers. comm.). A later visit on 21 August 1984 showed a total of 22 pairs with 50 nestlings in the nests (Len McDaniel, pers. comm.). A colony with 31 adults was noted by S. J. Dinsmore and W. R. Silcock on 6 August 1994 near Lewellen, Keith Co., and L. Blake noted another colony with an estimated 70 nests on 9 July 1994 south of Chambers in NE Garfield Co. (Silcock and Rosche 1994b). I found a single pair with a nest in a mixed heron colony on 19 June 2007 at CLNWR, Garden Co. and that colony had expanded to eight nests by 25 June 2009. Rare regular breeder, often in mixed colonies with other waders. Nests in emergent cattails as well as in trees. Nine colonies of 1-100 pairs reported. Twenty-six egg dates: 12 June - 7 August, no notable date clusters. Clutch sizes reported: 9 , usually 3 - 4 eggs, sometimes 2 - 5, mean 3.6, mode 4.

Green Heron, Butorides virescens. Fifteen records. First complete record: N. S. Goss collected a set of 5 eggs on 11 June 1890 from a nest beside Salt Creek, south of Lincoln, Lancaster Co., (UKBI, Cat. \#95572). L. Skow took 5 eggs on 20 May 1894 at Omaha, Douglas Co. (UKBI, Cat. \#95571). R. Mullen took 3 eggs on 29 May 1899 near Bellevue, Sarpy Co. (UNSM, Cat. \#ZM08208). J. E. Stipsky noted 2 young in a nest at Hooper, Dodge Co. (Stipsky 1934). I found a colony with four nests that held 3, 5, 5, \& 5 eggs on 17 May 2006 at Two Rivers SRA, Douglas Co. (Mollhoff 2006). It was again active with five nests holding 1, 4, 4, 4, \& 5 eggs on 14 May 2007 (Mollhoff 2008). K. Skaggs noted a nest with 2 eggs on 22 May 2011 in Norfolk, Madison Co. (Kent Skaggs, pers. comm.). Uncommon breeder, more common in the east, decreasing westerly, nearly absent in Panhandle. Usually a solitary nester. Nests in riparian woodlands, 7 - 37 $\mathrm{ft}$ ( $2-11 \mathrm{~m}$ ) up. Fifteen egg dates: 14 May - 14 June, no date clusters noted. Clutch sizes reported: 15, usually 3 - 5 eggs, sometimes 1 - 2, mean 4.2, mode 5 .

Black-crowned Night-Heron, Nycticorax nycticorax. One hundred six records. First record: J. L. Childs collected a set of 5 eggs on 19 May 1914 from the Oshkosh, Garden Co. area 
(FMNH, Cat. \#21400). A. M. Brooking took 3 eggs on 12 June 1920 in Garden Co. (HM, Cat. \#02197). J. H. Sather noted eight nests with 3 eggs apiece, and six nests with 4 eggs each on 22 June 1949 at VNWR, Cherry Co. (Sather undated). B. Cox reported a colony with 100+ nests in 1955 in a grove of elm trees by her house near Hershey, Lincoln Co. (Editor 1956b). R. S. Sharpe noted a colony of 150 pairs which included a nest with 4 eggs on 9 June 1965 at CLNWR, Garden Co. (CNRCP, \#82). Rare regular breeder, mostly in marshes in the Sandhills and the Rainwater Basin. Nests built in emergent cattails or rushes, with one colony found in trees. One hundred twenty-six egg dates: 8 May - 20 July ( 2 - 23 June $=90 \%$ ). Clutch sizes reported: 106, usually $3-4$ eggs, sometimes $1-5$, mean 3.0, mode 3.

Yellow-crowned Night-Heron, Nyctanassa violacea. Fifteen reports. An early report by Swenk was of an immature male he collected on19 July 1901 near Beatrice, Gage Co. (Swenk 1902b). First record: NOU members on a field trip at Fontenelle Forest, Sarpy Co., found a nest on 4 May 1963. The nest was incubated 17 - 28 May but was ultimately unsuccessful (Sharpe 1964). Since 1980 adults and/or young have been reported with increasing frequency, as noted in the following reports. On 18 June 1980 a juvenile "...that still had down feathers on various parts of its body and primary wing feathers that were not yet completely out of their sheaths..." was found in Lincoln, Lancaster Co. and was delivered by the Humane Society to Wildlife Rescue on 20 June. It was rehabbed and released. Later, on 8 July 1980 another juvenile was found near the airport (Ducey 1980). J. Jorgensen reported a "fresh juvenile" at Harvard Marsh, Clay Co., on 1 July 2001 (Silcock 2001). On 22 July 2012 an adult was seen feeding one of three accompanying young at Jack Sinn WMA, Saunders Co. (Clem Klaphake, pers. comm.). Sporadic breeder, most likely in the southeast. Nests in riparian woodlands. May - June sightings anywhere should be investigated for evidence of breeding.

\section{Family Threskiornithidae (Ibis)}

Glossy Ibis, Plegadis falcinellus. Three records. First record: J. G. Jorgensen flushed birds from nests with 5, 4, and 4 eggs at Harvard WPA, Clay Co., on 7 July 2015 (Jorgensen and Silcock 2015). Sporadic breeder but numbers and reports are increasing. Nests placed in emergent vegetation, especially in hemi-marshes with isolated cattail stands surrounded by open water. Only egg date is 7 July. Clutch sizes reported: 3 , usually 4 - 5 eggs, mean 4.3, mode 4.

White-faced Ibis, Plegadis chihi. Fifty-three records. First record: A. M. Brooking and E. Wallace collected a set of 4 eggs from a nest near Inland, Clay Co. on 4 June 1916 (Swenk 1918). While checking a known colony site on 22 June 1984 D. Emerick, accompanied by volunteer J. E. Ducey, found six nests, averaging 4 eggs each on Middle Marsh Lake, VNWR, Cherry Co. (Don Emrick, pers. comm.). G. Warrick photographed a well-grown young bird standing on its nest in June 1989 at CLNWR (Gordon Warrick, pers. comm.). A survey done at CLNWR in 1992 reported 46 nests, with 57 eggs and 9 young (NGPC archives). I found eleven nests with 2 - 4 eggs apiece on 5 June 2007 at Harvard WPA, Clay Co. I documented a colony of 10 nests, with 1 - 4 eggs and 2 - 4 young, on 23 June 2007 at Avocet WMA, Hyannis, Grant Co. P. Dunbar noted a nest with 2 eggs on 31 May 2008 at Hultine WPA, Clay Co. (Paul Dunbar, pers. comm.). Rare, but increasing, regular 
breeder, widely scattered almost statewide, especially in the Sandhills and Rainwater Basin. Nests preferably in hemi-marshes, placing its nests in isolated tall stands of emergent vegetation surrounded by open water. Ninety-one egg dates: 31 May - 8 July, ( 5 - 25 June $=86 \%$ ). Clutch sizes reported: 66 , usually $3-4$ eggs, sometimes $1-5$, mean 2.8 , mode 3 .

\section{Family Cathartidae (New World Vultures)}

Turkey Vulture, Cathartes aura. Twelve records. First record: J. S. Hunter noted a nest with 2 eggs on 9 May 1896 at Steven Creek, Lancaster Co. He noted another with two young on 18 June 1897 near the State Penitentiary, Lancaster Co. (Hatch and Garrels 1971). J. R. Bonwell took 2 eggs on 15 May 1897 near Nebraska City, Otoe Co. (FMNH, Cat. \#6166). P. A. Garrels found 2 young on 18 July 1970 on Wounded Knee Creek near the Nebraska border, Sheridan Co. (Hatch and Garrels 1971). M. J. Mossman and M. A. Brogie noted three nests with eggs or young 18 May - 21 August 1982 at NVP, Keya Paha Co. (Mossman and Brogie 1983). J. J. Dinan noted a nest with 2 young on 27 July 1983 near Milford, Seward Co., as well as a second nest with 2 young on 8 August 1983 near Fairbury, Jefferson Co. (CNRCP). Abundant regular breeder statewide. Nests usually found in empty buildings, beneath overhanging rock ledges, or in a hollow log. Eight egg dates: 15 May - 1 July. Twelve clutch sizes reported: 2 eggs is the only clutch size reported.

\section{Family Pandionidae (Ospreys)}

Osprey, Pandion haliaetus. Thirty-seven reports. Six records. First report: L. Bruner reported observing birds carrying food to a nest near Rockport, on the Douglas/Washington county line, near the Missouri River. Unfortunately he included no date or other details to complete the record (Bruner et al. 1904). The first modern record of nesting was at the opposite end of the state near Winters Creek Lake, Scotts Bluff Co., where a pair was building a nest atop a power pole 12 - 27 May 2008, but it was ultimately unsuccessful (Silcock 2008a). Following attempts by several pairs, young were finally documented in a nest near Scottsbluff on 19 June 2012, but were killed by a hail storm (Silcock 2012b). After attempts in Scotts Bluff, Keith, and Burt counties, young finally fledged successfully from a nest in Scottsbluff, Scotts Bluff Co. in late July 2015 (Silcock 2015b). No egg dates have been reported, although 1 - 3 young have been reported in nests.

\section{Family Accipitridae (Hawks, Kites, Eagles)}

Swallow-tailed Kite, Elanoides forficatus. Five reports. No documented nest record. Reports were more common in early settlement times. Three reports of nesting: "In Dixon County a pair nested for at least four years in succession on a cottonwood on Badger Creek." (Aughey 1878). I.S. Trostler reported to L. Bruner that "...a pair reported to breed 18 miles No. of Omaha." (Trostler 1896). Eiche was given a pair that had been killed on 8 August 1896, near Greenwood, Cass Co. where they had been nesting (Eiche 1901). There is a mounted specimen dated 1880 from Fullerton, Nance Co. (ISM, Cat.\#602725). 
Golden Eagle, Aquila chrysaetos. One hundred sixty-seven reports. Fifteen records. First record: G. E. Hudson found 2 large eaglets in a nest on 20 June 1938 at the Cook Ranch Headquarters, Agate, Sioux Co. (Hudson 1939). R. \& M. Witschy documented a nest from one tiny white fuzzy young on 8 May 1961, through a feathered chick five weeks old on 13 June, near Lake Minatare, Scotts Bluff Co. (CNRCP, \#5). R. Folchert noted a nest with 2 eggs on 25 April 1966 at Trunk Butte, Dawes Co. (CNRCP, \#29). D. B. Gates commented on "a new nest since last year" that held 2 young on 14 April 1968 at Trunk Butte, Dawes Co. (CNRCP, \#69). R. A. Lock noted a nest with 2 eggs on 5 April 1973 near Chadron, Dawes Co. (CNRCP, \#212). Rare regular breeder in the Panhandle. One hundred forty nests reported were on cliff ledges (87\%) and in trees (12\%). Twentythree egg dates: 13 March - 23 May (3 - 29 April =74\%). Clutch sizes reported: 15, usually 1 - 2 eggs, sometimes 3 , mean 1.8, mode 2 . Brood sizes in nests are comparable: 105 broods reported: usually 1 - 2 young, sometimes 3, mean 1.5, mode 1.

Northern Harrier, Circus hudsonius. Twenty-five records. First record: On 14 July 1857 W. S. Wood collected 2 eggs west of Ft. Kearny, NE (USNMNH, Cat. \#513). (Note: Ft. Kearny, Nebraska Territory, was established on the Platte River in 1858, in what is now Kearney Co., NE and discontinued in 1871. It was re-built and renamed Ft. Kearney State Park in 1959. Fort Phil Kearny was established on the Bozeman Trail in 1866 in what would become Wyoming). C. Pew took 4 eggs on 19 May 1890 near Hebron, Thayer Co. (CAS, Cat. \#4604). J. C. Crawford, Jr., took 5 eggs on 1 June 1898 near West Point, Cuming Co. (UNSM, Cat. \#ZM08318). A. M. Brooking took 3 eggs on 11 May 1919 near Inland, Clay Co. (HM, Cat. \#02200). G. E. Hudson noted 6 eggs on 21 May 1933 in Lancaster Co. (Editor 1933). W. Newell provided details on a nest with 6 eggs on 7 May 1948 near Powell, Jefferson Co. (Newell 1950). L. Blus noted a nest with 5 eggs on 30 June 1966 at the National Forest, Thomas Co. (CNRCP, \#135). Uncommon regular breeder in proper habitat statewide. Twenty-five nests reported, on the ground in grasslands, marshes, and alfalfa fields. Fifty-nine egg dates: 24 April - 14 July (24 April - 2 June $=88 \%$ ). Clutch sizes reported: 25, usually 5 - 6 eggs, sometimes 1 - 7, mean 4.8, mode 6 .

Sharp-shinned Hawk, Accipiter striatus. Seven records. First record: On 14 May 1895 N. S. Goss collected an egg from a nest near Ashland, Saunders Co. (UKBI, Cat. \#95576). M. Cary and J. C. Crawford, Jr., took 5 eggs on 30 May 1900 in Sioux Co. (UNSM, Cat. \#ZM08322). M. Cary took 4 eggs on 8 June 1901 at Warbonnet Canyon, Sioux Co. (UNSM, Cat. \#ZM08323). M. A. Carriker, Jr., took 3 eggs on 10 July 1901 at Warbonnet Canyon, Sioux Co. (UNSM, Cat. ZM08324). M. J. Mossman and M. A. Brogie found a nest with 4 eggs on 6 June 1982 in the NVP, Brown Co. (Mossman and Brogie 1983). Rare, probably regular, breeder; seems to prefer large tracts of woodland, especially with conifers, to place its nests. Seven egg dates: 10 May - 10 July (10 May - 8 June $=86 \%$ ). Clutch sizes reported: 5, usually 4 - 5 eggs, sometimes 1 - 3, mean 3.4, mode 4 .

Cooper's Hawk, Accipiter cooperii. Forty records. First record: H. A. Kline collected a set of 4 eggs from a nest in Gage (or Johnson) Co. on 11 May 1882 (Kline 1883a). N. S. Goss took 3 eggs on 25 June 1890 in Squaw Canyon, Sioux Co. (UKBI, Cat. \#95581). L. Skow took 5 eggs on 14 May 1893 at Booyer's Island, Omaha, Lancaster Co. (but the county should almost certainly be Douglas Co.) (UKBI, Cat. \#95578). M. A. Carriker, Jr., took 3 eggs on 26 April 1898 in Otoe Co. (WFVZ, Cat. \#97568). L. R. Sabine took 4 eggs on 30 April 1898 
at Omaha, Douglas Co. (WFVZ, Cat. \#98852). D. Chase took 3 eggs on 17 May 1899 in Sarpy Co. (NYSM, Cat. \#ZO-12014). Uncommon regular breeder, it is currently increasing statewide. Nests in trees, often in riparian woodlands, and now regularly found in residential areas. Forty-three egg dates: 12 April - 25 June (26 April - 18 May =81\%). Clutch sizes reported: 30, usually 4 - 5 eggs, sometimes 2 - 3, mean 4.1, mode 4.

Bald Eagle, Haliaeetus leucocephalus. Sixty-one reports, twenty-one records. There are several historical reports. Prince Maximilian reported seeing a nest on 10 May 1833 in what is now Dixon Co. but made no further comment (Orr and Porter 1983). J. K. Townsend reported a nest with young on 25 May 1834 on the North Platte River near the Keith/Garden Co. line (Jobanek 1999). J. H. Carleton noted a nest with young on 9 June 1845, near Townsend's sighting (Carleton 1983). An early report cited a pair nesting near Omaha, but gave no details (Taylor and Van Vleet 1889). An early list cited breeding at several locations (Bruner 1896), but a later list stated that "It probably formerly bred....but there are no definite breeding records (Bruner et al. 1904). The first documented record is of a pair that built, tended, and later abandoned a nest in Cedar Co., in 1973 (Lock and Schuckman 1973). The first successful nest was along the Platte River near Ashland, Sarpy Co., but the chick died before fledging (Editor 1991). The first documented nest that successfully fledged young was at the same unidentified site in 1992 (Editor 1992). More than 100 active nests are now reported annually (Jorgensen et al. 2010). Uncommon regular breeder, nests in riparian woodlands statewide. Nests placed high in trees near water. The following egg and brood reports are limited due to special protection of the species, as well as inaccessibility of nests. Thirteen egg dates (based on observation of adults in incubating posture) are 19 February - 7 April. Nineteen brood reports of nests with young indicate usual brood sizes of 2 - 3 chicks, sometimes only a single chick.

Mississippi Kite, Ictinia missippiensis. Twenty-two reports, six records. First record: S. J. Dinsmore and W. R. Silcock reported a nest with 2 nearly full-grown young in Ogallala, Keith Co. on 6 August 1994 (Dinsmore and Silcock 1995). S. J. Dinsmore and B. \& L. Padelford noted a nest with a downy young on 11 August 1996 in Ogallala, Keith Co. (Silcock and Jorgensen 1996). C. W. Huntley noted a nest with 2 eggs on 21 June 2002 in Ogallala, Keith Co. (Silcock 2002). T. J. Walker noted a bird incubating a nest on 9 July 2012 in North Platte, Lincoln Co. (Silcock 2012b); included in that report is a list of locations that document the recent, rapid expansion of its breeding range to that time. Extremely rare regular breeder, rapidly expanding its range in towns, especially in the southern and southwestern part of the state. Nests reported $35-40 \mathrm{ft}(11-12 \mathrm{~m})$ up in trees in residential areas. Two egg dates: 21, 22 June. Nests with young reported 25 July - 13 August. Fledged young noted by 22 August. Clutch size: only a single clutch of 2 eggs reported.

Red-shouldered Hawk, Buteo lineatus. Eighteen reports, four records. First record: M. A. Carriker, Jr., collected 2 eggs from a nest $60 \mathrm{ft}(18 \mathrm{~m})$ up a cottonwood, south of Nebraska City, Otoe Co. on 11 April 1899 (Carriker 1900). C. A. Stewart found a nest with 3 little white heads visible at Fontenelle Forest, Sarpy Co. on 30 April 1943 (Stewart 1943). On 9 May 2009, L. Einemann found a nest with 2 young at Pawnee Lake SRA, Lancaster Co. (Larry Einemann, pers. comm., Silcock 2009b). Extremely rare, but 
might be a regular breeder. All reports are from riparian habitat. Thirty-one egg dates: 1 March - 17 May (11 April - 10 May =80\%). Clutch sizes reported: 4, usually 2 - 3 eggs, sometimes 1 , mean 2.3, mode 2 .

Broad-winged Hawk, Buteo platypterus. Sixteen reports, six records. First record: On 3 May 1889 G. A. Coleman collected an egg at Peru, Nemaha Co. (Coleman undated). C. A. White collected 2 eggs from a nest in Douglas Co. on 15 May 1892 (White 1893). L. Skow collected 2 eggs from a nest at Omaha, Douglas Co. on 21 May 1893 (UKBI, Cat. \#95582). On 19 May 1901 R. B. Mullen collected 2 eggs from a nest on Child's Point, Sarpy Co. (Shoemaker undated). On 26 May 1901 F. H. Shoemaker photographed a nest with 2 eggs (\#A41) in Fontenelle Forest (Shoemaker undated). Extremely rare, restricted to Missouri River valley, except for birds that nested 2008 - 2014 in North Platte, Lincoln Co. Nests usually placed well up in tree. Eight egg dates: 2 - 26 May, no date clusters noted. Clutch sizes reported: 4, usually 2 eggs, sometimes 1 - 3, mean 2.0, mode 2.

Swainson's Hawk, Buteo swainsoni. Twenty-three records. First record: C. A. White collected a set of 2 eggs near Omaha, Douglas Co. on 20 April 1891 (White 1893). N. S. Goss took 3 eggs on 18 May 1895 near Hickman, Lancaster Co. (UKBI, Cat. \#95584). F. Buckstaff and R. H. Wolcott took 3 eggs on 11 May 1898 near Lincoln, Lancaster Co. (UNSM, Cat. \#ZM08374). J. L. Childs took 3 eggs on 26 May 1908 on the Dismal River, Thomas Co. (FMNH, Cat. \#20518), and another 3 eggs there on 27 May 1908 (WFVZ, Cat. \#13145). J. T. Zimmer took 3 eggs on 10 June 1912 at the National Forest, Thomas Co. (Zimmer undated). L. Blus noted a nest with 2 eggs on 11 June 1965 near Seneca, Thomas Co. (CNRCP, \#5). Common regular breeder, formerly statewide; now mainly in the west, nearly absent in the east and southeast. Nests placed in trees $5-50 \mathrm{ft}(1.5-15 \mathrm{~m}) \mathrm{up}$, usually 15 - $35 \mathrm{ft}$ (5 - $11 \mathrm{~m}$ ). Fifty egg dates: 20 April - 1 July (8 May - 6 June $=70 \%$ ). Clutch sizes reported: 23, usually 2 - 3 eggs, sometimes $1-4$, mean 2.8, mode 3.

Red-tailed Hawk, Buteo jamaicensis. Thirty-five records. First record: On 6 May $1882 \mathrm{H}$. A. Kline found a nest with 4 young, $58 \mathrm{ft}(18 \mathrm{~m})$ up a red elm in Gage (or Johnson) Co. (Kline 1883a). N. S. Snow took 2 eggs on 9 April 1891 at Jamaica, Lancaster Co. (UKBI, Cat. \#95587). L. Skow took 3 eggs on 2 April 1893 at Omaha, Douglas Co. (WFVZ, Cat. \#209415). G. W. Fabretti took 2 eggs on 1 March 1898 on Papio Creek, Douglas Co. (YPM, Cat. \#ORN130212). A. Brown took 2 eggs on 10 April 1898 at Omaha, Douglas Co. (NYSM, Cat. \#ZO-12061). J. Burnett took 2 eggs on 29 April 1905 at Nebraska City, Otoe Co. (UNSM, Cat. \#ZM08357). Abundant breeder state-wide, nests placed in scattered trees or at edge of woodlands, both rural and urban. Forty nests were placed $16-105 \mathrm{ft}$ $(5-32 \mathrm{~m})$ high $(40-60 \mathrm{ft}(12-18 \mathrm{~m})=73 \%)$. Fifty-five egg dates: 1 March - 28 June (20 March - 20 April =71\%). Clutch sizes reported: 35, usually 2 - 3 eggs, sometimes 1 - 4, mean 2.3, mode 2)

Ferruginous Hawk, Buteo regalis. One hundred thirteen reports, fifteen records. First record: W. C. Smith collected an egg from a nest on 10 June 1898 near Long Pine, Brown Co. (SBM, Cat. \#59). F. M. Dille took 4 eggs on 7 May 1922 at Ft. Niobrara, Cherry Co. (WFVZ, Cat. \#157272). D. DeGroot took 3 eggs on 5 April 1948 near Potter, Cheyenne Co. (WFVZ, Cat. \#61433). G. A. Wingfield reported 1 egg, plus 3 young on 10 June 1981 near Dunlap, Dawes Co. (CNRCP). J. J. Dinan banded 3 young on 10 June 1982, 16 mi. W. 
of Marsland, Sioux Co. (CNRCP). D. E. Carlson noted 3 eggs on 22 May1984, $\mathrm{N}$ of Hemingford, Box Butte Co. (CNRCP). Rare regular low-density breeder in open grasslands in the Panhandle, occasionally in adjacent Sandhills. Nests often near prairie dog towns, usually on cliff ledges (60\%), or in trees (35\%). Egg dates: 26 March - 19 June (21 April - 19 May =86\%). Clutches reported: 15, usually 2 - 3 eggs, sometimes 1 - 4, mean 2.6, mode 3 .

\section{Family Tytonidae (Barn Owls)}

Barn Owl, Tyto alba. Thirty-four records. First record: I. S. Trostler collected a set of 3 eggs on 12 June 1891 near Hebron, Thayer Co. (Trostler 1896). J. T. Zimmer took 4 eggs on 29 April 1909 at Waverly, Lancaster Co. (Zimmer undated). R. E. Dodge took a set of eggs on 20 May 1915 in Boone Co. (HM, Cat. \#02744). W. Tout noted a pair with 2 eggs in a riverbank hole on 9 April 1933 near North Platte, Lincoln Co. (Tout 1947). R. H. Brashears noted 6 eggs on 15 April 1976 in a fire lookout tower at CLNWR, Garden Co. (CNRCP, \#276). G. A. Wingfield noted 8 eggs on 27 May 1980 atop the corn in a grain bin near Hershey, Lincoln Co. (CNRCP). Rare regular breeder statewide, but more numerous in the south and Panhandle. Lays its eggs in holes in vertical dirt banks or cliffs (25\%), in unoccupied buildings (38\%), under bridges (4\%), or in purpose-built nest boxes (31\%). Two hundred thirty-nine egg dates: 4 April - 6 August (17 May - 25 June $=74 \%)$. Clutch sizes reported: 33, usually 5 - 6 eggs, sometimes $1-12$, mean 5.6, mode 6 .

\section{Family Strigidae (Typical Owls)}

Eastern Screech-Owl, Megascops asio. Thirty-one records. First record: H. A. Kline collected a set of 3 eggs in Gage (or Johnson) Co. on 23 April 1882 (Kline 1883a). Mr. McClellean took 4 eggs on 12 April 1888 at Nebraska City, Otoe Co. (WFVZ, Cat. \#87131). M. Pew took 4 eggs on 18 April 1891 at Hebron, Thayer Co. (WFVZ, Cat. \#135761). L. Robbins took 4 eggs on 2 April 1894 near Lincoln, Lancaster Co. (UKBI, Cat. \#95642). L. J. Pickett took 3 eggs on 17 May 1895 at Wahoo, Saunders Co. (WFVZ, Cat. \#114846). W. C. Smith took 1 egg on 10 May 1897 near Long Pine, Brown Co. (SBM, \#51). A. S. Pearse took 4 eggs on 27 April 1899 at Lincoln, Lancaster Co. (USNMNH, Cat. \#B29732). Uncommon breeder statewide, nesting in woodlands, residential areas in towns, and farmsteads. Nests in natural tree cavities and nest boxes. One hundred sixteen egg dates: 22 March 13 June (17 April - 7 May =72\%), dates later than mid-June are probable re-nests after a failed attempt. Clutch sizes reported: 31, usually 3 - 5 eggs, sometimes 1 - 6, mean 4.1, mode 4.

Great Horned Owl, Bubo virginianus. Sixty records. First record: Mr. McClellean collected a set of 2 eggs from a nest near Nebraska City, Otoe Co. on 2 March 1888 (WFVZ, Cat. \#211822). W. C. Smith took 1 egg on 10 March 1897 near Long Pine, Brown Co. (SBM, Cat. \#55). E. Wallace took 2 eggs on 3 March 1900 near Pries Lake, Douglas Co. (WFVZ, Cat. \#70036). J. B. Burnett took 2 eggs on 11 March 1910 at Nebraska City, Otoe Co. (UNSM, Cat. \#ZM08427). L. C. Holcomb noted 3 eggs on 27 February 1966 at Fremont, Dodge Co. (CNRCP, \#350). Common breeder statewide, nesting in every habitat. Almost never builds own nest, usually uses old nests of hawks, crows, herons, squirrels, or lays eggs on grain in open bin, floor of barn, bridge, tree crotch, in hollow tree, or hole in 
vertical dirt or rock face. Often shares nests with Red-tailed Hawk on alternate years. One nest evidently built by the owl was a handful of twigs piled into a small ash tree fork, with the eggs visible through the bottom of the 'nest'. Nest heights recorded were 5 - $105 \mathrm{ft}$ (1.5 - $32 \mathrm{~m})$. One hundred four egg dates: 18 January - 13 April (18 February 17 March $=77 \%)$. Clutch sizes reported: 60 , usually 2 eggs, sometimes 1 - 3, mean 2.2, mode 2.

Burrowing Owl, Athene cunicularia. Thirty-eight reports, seven records. First record: H. A. Kline dug out a nest on 18 May 1882 in what appeared to be a skunk burrow and found 2 eggs, plus 9 young owls, in Gage (or Johnson) Co. (Kline 1883a). G. E. Verrill took 4 eggs on 6 April 1890 near Lincoln, Lancaster Co. (ROM, Cat. \#504728). F. A. Colby took 7 eggs on 19 May 1895, and A. S. Pearse took 5 eggs on 26 May 1895, both in Gage Co. (Pearse 1896). W. C. Smith took 1 egg on 10 July 1896 near Long Pine, Brown Co. (SBM, Cat. \#47). A. M. Brooking took 2 eggs in 1914 near Funk, Phelps Co. (HM, Cat. \#02286). N. V. Radford noted 1 egg on 16 July 1974 at a nest burrow evidently destroyed by a badger, Taxidea taxus (CNRCP, \#63). Uncommon regular breeder, nests in grasslands, usually placed in uninhabited prairie dog burrows, but also uses empty dens of skunk and badger. Eight egg dates reported: 6 April - 10 July, no notable date clusters, but any after mid-June are likely second attempts. Fifty-two reports of young birds noted at the nest site: 18 May - 30 July (16 June - 16 July =77\%), with a single late report on 4 September. Clutch sizes reported: 7, usually 3 - 7 eggs, sometimes 8 - 11 eggs, mean 6.4, mode 5. Brood sizes reported: 2 - 7 chicks, mean 3.7, mode 3.

Barred Owl, Strix varia. Eighteen records. First record: Mr. McClellean collected 2 eggs on 2 March 1888 near Nebraska City, Otoe Co. (WFVZ, Cat. \#211400). J. R. Bonwell took 3 eggs on 8 March 1893 at Nebraska City, Otoe Co. (WFVZ, Cat. \#114079). M. A. Carriker, Jr., took 3 eggs on 26 March 1896 in SE Otoe Co. (WFVZ, Cat. \#114080). G. W. Morse took 2 eggs on 6 March 1898 at Childs Woods, Sarpy Co. (WFVZ, Cat. \#48203). R. Mullen took 2 eggs on 9 April 1899 at Child's Point, Sarpy Co. (WFVZ, Cat. \#73801). Rare breeder in mature woodlands in eastern Nebraska, may be expanding slowly westward as riparian woodlands mature into trees large enough to provide nest cavities. Most nests in cavities (6), or nest boxes (7), with one in an open stick nest. Forty-five egg dates reported: 2 February - 7 April (6 - 26 March =69\%). Clutches sizes reported: 18 , usually 2 - 3 eggs, sometimes 1 - 4, mean 2.7, mode 2 .

Long-eared Owl, Asio otus. Twenty-five records. First record: H. A. Kline collected a set of 5 eggs from a nest in Gage (or Johnson) Co. on 21 April 1882 (Kline 1883a). M. A. Carriker, Jr., took 4 eggs on 6 April 1894 in Otoe Co. (MVZ, Cat. \#5967). I. S. Trostler took 3 eggs on 25 April 1897 near La Platte, Sarpy Co. (WFVZ, Cat. \#46829). G. M. Sutton took 3 eggs on 1 May 1898 in Sarpy Co. (CM, Cat. \#E9826). J. T. Zimmer took 6 eggs on 12 April 1909 near Walton, Lancaster Co. (Zimmer undated). L. A. Peterson noted 6 eggs on 27 April 1958 in Hall Co. (CNRCP, \#1). R. A. Lock noted 5 eggs on 4 May 1978 near Pawnee Lake SRA, Lancaster Co. (CNRCP). Rare regular breeder, probably statewide, but hard to detect. Nests in woodlands, may prefer stands of mixed conifer-hardwood, frequently uses old crow nests. Twenty-five egg dates: 22 March - 16 May, no date clusters noted. Clutch sizes reported: 25 , usually 4 - 5 eggs, sometimes $3-6$, mean 5.2 , mode 5 . 
Short-eared Owl, Asio flammeus. Twenty-one reports, seven records. First record: On 17 May $1882 \mathrm{H}$. A. Kline collected a set of 8 eggs from a nest in Johnson Co. (SMNH, Cat. $\# 14971$ ). Kline also reported that another nest there in 1880 held 1 egg and 6 young (Kline 1883b). W. C. Smith collected an egg near Long Pine, Brown Co. on 10 May 1897 (SBM, Cat. \#50). S. R. Young found a bird incubating 7 eggs, 7 - 23 May 1966 near Redington, Banner Co. (CNRCP). On 2 June 1967 J. E. Wilbrecht found a nest with 7 eggs "about $50 \mathrm{ft}$ (15 m) from an active pintail nest" at CLNWR, Garden Co. (CNRCP). H. Gunderson found a nest with 3 young at CLNWR, Garden Co., on 8 June 1967 (CNRCP). On 9 May 1988 L. McDaniel found a nest with 3 eggs and 4 young at VNWR, Cherry Co. (Len McDaniel, pers. comm.). Extremely rare, probably regular breeder, formerly statewide prior to homesteading, may now be limited to the Panhandle and Sandhills. Ground nester, has been recorded breeding in tallgrass and shortgrass prairie, wet meadow, and fallow wheat stubble fields. Forty-five egg dates: 7 May - 15 June, no date clusters noted. Clutch sizes reported: 7, usually 7 eggs, sometimes 8, mean 7.2, mode 7 .

Northern Saw-whet Owl, Aegolius acadicus. Nine records. First record: Although there is an early undated, second-hand report from Otoe Co. (Carriker 1900), the first documented record is by L. McDaniel of a pair of adults with 3 fledged young at the Hackberry Lake Headquarters, VNWR, Cherry Co., on 24 June 1978 (Mollhoff 2005b). A nest box study is currently underway (Mollhoff 2018). Rare regular breeder, most common in the Panhandle, breeds at widely scattered locations almost state-wide. Eighty egg dates, from 8 nests: 5 February - 30 April (12 March - 19 April =58\%). Clutch sizes reported: 7, usually 6 eggs, sometimes 5 - 7, mean 6.0, mode 6. Fledged young reported 11 April - 25 May.

\section{Family Alcedinidae (Kingfishers)}

Belted Kingfisher, Megaceryle alcyon. Eight records. First record: On 11 May 1885 L. Bruner collected a set of 6 eggs from a nest burrow near West Point, Cuming Co. (UKBI, Cat. \#95651). N. S. Goss collected a set of 5 eggs in Lincoln, Lancaster Co. on 11 May 1889 (UKBI, Cat. \#95653). On 29 May 1894 L. Skow collected 7 eggs at Hardwood Lake, Omaha, Douglas Co. (UKBI, Cat. \#95652). W. C. Smith collected an egg near Long Pine, Brown Co., on 10 April 1897 (SBM, Cat. \#48). On 1 June 1899 M. H. Swenk collected 5 eggs near Beatrice, Gage Co. (UNSM, Cat. \#ZM08456). J. Fredrickson collected 6 eggs at a sandpit on Child's Point, Sarpy Co. on 24 May 1900 (UNSM, Cat. \#ZM08457). C. A. Black collected 4 eggs near Kearney, Buffalo Co. on 5 May 1925 (HM, Cat. \#21935). On 20 May 1972 W. A. Schleicher found a nest (which the pair was still enlarging) with 5 eggs near Grand Island, Hall Co. (CNRCP). Common breeder statewide, along watercourses with vertical earthen banks where they can excavate their nest burrows. Eleven egg dates: 10 April - 4 July, no date clusters. Clutch sizes reported: 8, usually 4 - 6 eggs, mean 5.2, mode 5 . 


\section{Family Picidae (Woodpeckers)}

Lewis's Woodpecker, Melanerpes lewis. Twenty-one reports. Seven records. First record: W. J. Mollhoff found a nest with 5 eggs in a pine snag SE of Crawford, Dawes Co. on 12 June 1999 (Mollhoff 2000a). The same nest held 6 eggs on 2 June 2000. I found a nest with 3 eggs near there on 1 June 2001. The next year it held 1 egg and 5 young on 21 June 2002, while another nest in the area held 7 eggs on 22 June 2002. Sporadic breeder in the Panhandle. Usually nests in the dead pine snags still standing after a wildfire. Nine nest heights reported: 16 - $60 \mathrm{ft}(5-18 \mathrm{~m})$ high. Usually a single pair, or a few pairs, breed for 5-10 years in the same area, then disappear. Seven egg dates: 1 - 22 June, no date clusters noted. Clutch sizes reported: 5 , usually 5 - 7 eggs, sometimes 3 , mean 5.4 , mode 6 .

Red-headed Woodpecker, Melanerpes erythrocephalus. Forty-seven reports, seven records. First record: M. Pew collected 6 eggs from a nest in a willow snag near Hebron, Thayer Co. on 28 June 1890 (YPM, Cat. \#146087). F. H. Andrews collected 7 eggs from a nest at Omaha, Douglas Co. on 7 June 1891 (MCZ, Cat. \#360014). On 15 June 1896 W. C. Smith collected an egg near Long Pine, Brown Co. (SBM, Cat. \#22). E. West collected 5 eggs at Omaha, Douglas Co. on 22 June 1897 (UNSM, Cat. \#ZM08474). M. A. Carriker, Jr., collected a set of 5 eggs in Otoe Co. on 30 May 1898 (UNSM, Cat. \#08471). M. H. Swenk collected 4 eggs near Beatrice, Gage Co. on 9 June 1901 (UNSM, Cat. \#ZM08472). On 3 June 1915 A. M. Brooking collected 2 eggs at Inland, Clay Co. (HM, Cat. \#02280). R. W. Dawson collected 7 eggs at Mitchell, Scotts Bluff Co. on 28 June 1916 (UNSM, Cat. \#ZM08473). R. W. Dawson and C. E. Mickel found a nest with 6 eggs near Mitchell, Scotts Bluff Co. on 26 June 1916 (Mickel and Dawson 1916). Abundant breeder statewide, occupies woodlots, old wildfire burns, shelterbelts, and other woodland edge habitats. Excavates its nests in large dead branches or in dead trees, holes placed 7 - 40 $\mathrm{ft}(2-12 \mathrm{~m}$ ) high. Nineteen egg dates: 25 May - 28 June, no notable date clusters. An outlier date of 6 August is likely a second attempt. Clutch sizes reported: 7, usually 5 - 7 eggs, sometimes 2 - 4, mean 5.7, mode 6 .

Red-bellied Woodpecker, Melanerpes carolinus. Fifteen reports, two records. First record: On 3 May 1897 M. A. Carriker, Jr., collected a set of 5 eggs from a nest $30 \mathrm{ft}(9 \mathrm{~m})$ up in a dead willow snag in Otoe Co. (UNSM, Cat. \#ZM08479). A nest with 1 egg and 4 young was monitored in Ashland, Saunders Co. 17 May - 12 June 2000 (Mollhoff 2001b). Common regular breeder, initially limited to eastern Nebraska, expanded along developing riparian woodlands to Howard Co. by the 1940s (Wm. Lemburg, pers. comm.), Hayes, Garden and Sioux counties by late 1980s. A weak excavator, six out of ten nests reported were high in dead willow snags, the instability of which may account for the paucity of detailed reports. Twenty-two egg dates (from two nests): 3 May - 1 June, no date clusters. Nests with young reported 27 May - 29 June. Two clutch sizes reported: both with 5 eggs, mean 5.0, mode 5 .

American Three-toed Woodpecker, Picoides dorsalis. Six reports. No confirmed breeding noted. Single male and female birds were noted in East Ash Creek canyon, Dawes Co., 4 June 25 October 2014 (Silcock 2014b), and a female was observed going in and out of a fresh nest cavity on 19 October 2014 (Mark Brogie, pers. comm.). In June - July 2015, a pair 
was noted in the same area. Sharpe et al. (2001) summarized previous breeding season reports.

Downy Woodpecker, Dryobates pubescens. Sixteen records. First record: A set of 5 eggs was collected at Jamaica, (near Roca), Lancaster Co. on 12 May 1891 by N. H. Goss (UKBI, Cat. \#95650). A. S. Pearse collected 5 eggs near DeWitt, Gage Co. on 14 May 1894 (USNMNH, Cat. \#B29740). M. A. Carriker, Jr., collected 6 eggs in Otoe Co. on 14 May 1897 (UNSM, Cat. \#ZM08461). W. C. Smith collected 2 eggs near Long Pine, Brown Co. on 15 June 1897 (SBM, Cat. \#8). M. A. Carriker collected 5 eggs at Otoe, Otoe Co. on 7 May 1898 (USNMNH, Cat. \#B44046). R. H. Wolcott collected 5 eggs from a nest in a fencepost at Lincoln, Lancaster Co. on 8 May 1898 (UNSM, Cat. \#ZM08466). M. A. Carriker, Jr., collected 5 eggs on 13 May 1898 in Otoe Co. (DMNS, Cat. \#1096). On 13 May 1899 M. A. Carriker, Jr., took 5 eggs from a nest in Otoe Co. (WFVZ, Cat. \#212122). Abundant regular breeder in wooded areas statewide. Nests in wide variety of woodlands, including residential areas and parks. Twenty nests reported $3-26 \mathrm{ft}$ (1 - 8 $\mathrm{m}$ ) high. Twenty-one egg dates: 4 May -15 June (4 - 23 May =92\%). Clutch sizes reported: 12, usually 4 - 5 eggs, sometimes 2 - 7, mean 4.7, mode 4 .

Hairy Woodpecker, Dryobates villosus. Twenty-two reports, five records. First record: W. C. Smith collected an egg from a nest near Long Pine, Brown Co. on 16 July 1898 (SBM, Cat. \#18). R. Mullen collected 3 eggs at Child's Point, Sarpy Co. on 20 May 1899 (UNSM, Cat. \#ZM08460). J. C. Crawford collected 4 eggs on 28 May 1900 in Monroe Canyon, Sioux Co., and on 29 May 1900, he collected 3 eggs at another nest in Monroe Canyon, Sioux Co. (Crawford 1901). W. J. Mollhoff found a nest with 2 eggs and 3 young in West Ash Creek canyon on 1 June 2002 (Mollhoff 2004b). Uncommon regular breeder statewide in mature woodlands. Much less common than Downy Woodpecker, also seems less tolerant of human proximity. Nine nests were $6-35 \mathrm{ft}(2-11 \mathrm{~m})$ high. Strong excavator, often nests in living green ash trees (Fraxinus pennsylvanica). Seven egg dates: 20 May - 16 July, no notable date clusters, but July date likely a failed first attempt. Clutch sizes reported: 5, usually 4 - 5 eggs, sometimes 1 - 3, mean 4.2, mode 5 . Northern Flicker, Colaptes auratus. Thirty-five records. First record: On 11 June 1887 L. Bruner collected a set of 9 eggs from a nest near West Point, Cuming Co. (UKBI, Cat. \#95648). On 1 May 1889 M. Penn collected 7 eggs near Hebron, Thayer Co. (WFVZ, Cat. \#212359). On 20 May 1892 L. Robbins collected a set of 13 eggs at Saltillo, Lancaster Co.(UKBI, Cat. \#95649). On 12 May 1893 N. S. Goss collected 8 eggs at Emerald, Lancaster Co. (UKBI, Cat. \#95647). On 4 May 1894 A. S. Pearse took 10 eggs from a nest in Gage Co. (Pearse 1896). On 14 May 1897 M. A. Carriker collected 9 eggs in Cass Co.(UNSM, Cat. \#ZM08480). On 10 June 1897 W. C. Smith took 2 eggs near Long Pine, Brown Co. (SBM, Cat. \#45). On 16 April 1898 W. Tout found 7 eggs in a dead cottonwood near York, York Co. (Tout 1901). On 19 May $1898 \mathrm{~J}$. C. Crawford collected 6 eggs "South of Penn[itentary]" at Lincoln, Lancaster Co. (UNSM, Cat. \#ZM08487). On 25 May 1898 R. H. Wolcott collected 8 eggs at Lincoln, Lancaster Co. (UNSM, Cat. \#ZM08484). On 29 May 1913 J. T. Zimmer collected 7 eggs from a nest near Ravenna, Buffalo Co. (Zimmer, undated). Abundant regular breeder statewide, uses a wide variety of woodland edge habitats, from scattered trees and woodlots, to residential neighborhoods and forest edges. Forty-two nest cavities were 4 - $40 \mathrm{ft}$ (1.2 - $12 \mathrm{~m}$ ) high. Seventy-seven egg dates: 
16 April - 1 July (12 May - 12 June $=68 \%$ ). Clutch sizes reported: 27 , usually 7 - 8 eggs, sometimes 4 - 13, mean 7.0, mode 7.

Pileated Woodpecker, Dryocopus pileatus. Twelve reports. Sharpe et al. (2001) summarize the early history of the species, noting that there had been no reports of nesting. The first indication of breeding activity was nest-building on 2 May 1999, at Fontenelle Forest, Sarpy Co. (Silcock and Jorgensen 1999). Young birds were noted in the nest on 17 June and were fledged by 10 July 1999 (Silcock 1999b). They have nested regularly there since, and were also documented nesting at Indian Cave State Park, Richardson Co. in 2002 (Mollhoff 2004b). No egg dates have been recorded. Thirty-three reports of nests with young are 11 May - 19 June.

\section{Family Falconidae (Falcons)}

American Kestrel, Falco sparverius. Fifty-five records. First record: On 1 June 1896 W. C. Smith collected an egg from a nest near Long Pine, Brown Co. (SBM, Cat. \#42). On 7 May 1898 M. A. Carriker, Jr., collected 5 eggs in Otoe Co. (Carriker 1900). On 24 May 1901 M. A. Carriker, Jr., collected an egg near Crawford, Dawes Co. (UNSM, Cat. \#ZM08386). On 16 May 1903 F. M. Dille took 5 eggs at Ft. Niobrara, Cherry Co. (WFVZ, Cat. \#110498). On 8 June 1979 R. A. Lock found a nest with 5 eggs near Crawford, Dawes Co. (CNRCP). On 8 June 1988 J. J. Dinan found a nest with 4 eggs near Gretna, Sarpy Co. (CNRCP). On 27 May 1988 C. Stonerook reported a nest with 5 young near Lincoln, Lancaster Co. (CNRCP). Abundant regular breeder statewide, wherever it can find a cavity to hold its nest. Cavities of Northern Flicker probably provide most nest sites, but it regularly usurps Lewis's Woodpecker holes, readily uses nest boxes, as well as holes in dirt banks and cliffs. Fifty-four egg dates: 26 March - 29 June, (7 April - 7 May =41\%) (27 May - 8 June $=41 \%)$. Dates after 26 May probably represent second clutches. Clutch sizes reported: 55, usually 4 - 5 eggs, sometimes 2 - 6, mean 4.5, mode 5 .

Merlin, Falco columbarius. Eleven records. First record: While researching raptors in the Pine Ridge on 13 June 1975 R. A. Lock and R. Craig discovered a nest with 2 eggs at Ft. Robinson State Park, Sioux Co. (Lock and Craig 1975). On 9 June 1978 Lock found a nest built atop a magpie nest, with 1 egg and 4 young near Crawford, Dawes Co. (CNRCP). On 13 June 1980 Lock found a nest 14 mi NW of Crawford in Sioux Co., and another on 17 June 1980 14 mi WNW of Crawford, Sioux Co. (CNRCP). On 7 June 1983 J. J. Dinan found a nest with 2 eggs 14 mi WNW of Crawford, Sioux Co. (CNRCP). Extremely rare, but possibly regular breeder in the Pine Ridge. All nests reported were placed in pines, and most breeding season sightings have been in pine woodlands. Ten egg dates: 7 - 15 June. Clutch sizes reported: 9, usually 5 eggs, sometimes 2 - 4, mean 3.5, mode 5 .

Peregrine Falcon, Falco peregrinus. Thirteen records. First report of possible breeding: On 5 - 19 August 1903 L. Bruner observed "...old and young birds flying about the cliffs 8 miles west of Ft. Robinson, going in and out of a recess that may have been the nesting site." (Bruner et al. 1904). However, since the young were fledged, and fledging normally occurs in June, the birds might have been migrating. Re-introduction efforts in Omaha began in 1988 and the first successful fledging took place in 1994 (Forsberg 1997). Modern breeding in Nebraska has been limited to nest boxes on high-rise buildings in 
the urban 'canyons' of Omaha and Lincoln. Egg dates range 26 March - 21 May (3 April 5 May =93\%).Clutch sizes reported: 13 , usually 4 - 5 eggs, sometimes $2-3$, mean 3.7, mode 4 (Silcock and Jorgensen 2018).

Prairie Falcon, Falco mexicanus. Thirty-seven records. First record: On 26 May 1901 M. A. Carriker, Jr., L. Bruner, and M. Cary found a nest with 1 egg and 2 just-hatched young near the top of Saddle Butte, just west of Crawford, Dawes Co. (Carriker 1902). On 21 June 1901 M. A. Carriker, Jr., found a nest with 5 young in Warbonnet Canyon, Sioux Co. (Carriker 1902). On 24 April 1906 P. B. Peabody and H. Ihrig found a nest with 5 eggs near Crawford, Dawes Co. (FMNH, Cat. \#6833). On 29 April 1936 L. R. Wolfe took a set of 4 eggs near Harrisburg, Banner Co. (WFVZ, Cat. \#15649). On 6/7 June 1972 L. D. Robinson found 3 eggs in a nest near Chadron, Dawes Co. (Fiala 1973). On 10 June 1974 R. A. Lock banded 4 young at each of 2 nests south of Chadron, Dawes Co. On 11 June 1974, he saw 5 young at a nest west of Crawford, Sioux Co., on 13 June 1974 he banded 4 young NE of Harrison, Sioux Co. On 14 June 1974 he banded 2 young SSW of Chadron, Dawes Co. (CNRCP). During 8 - 17 June 1975, Lock reported banding 35 of 41 young at 10 nests in Banner, Dawes, and Sioux counties (CNRCP). During 5 - 8 June 1984 J. J. Dinan reported 37 young at 9 nests in Banner, Dawes, and Sioux counties (CNRCP). Rare regular breeder in the canyons and buttes of the Panhandle. Eggs laid on a ledge or in a cavity in the face of a cliff. Six egg dates: 24 April -8 June, no date clusters noted. Clutch sizes reported: 37 , usually $4-5$, sometimes $2-3$, mean 4.1 , mode 5 .

\section{Family Psittacidae (Parrots)}

Monk Parakeet, Myiopsitta monachus. Seven reports. No documented breeding records. First reported on 28 October 1972, a pair built a nest in Omaha, Douglas Co., over-wintered, but left in April 1973 (Padelford and Padelford 1973). Birds have since been noted in Kearney, Buffalo Co. in 1975 (Bliese 1975), and in 1975 in Lincoln, Lancaster Co. (Di Silvestro 1975). In 1998 a pair or more built at least 2 nests in Omaha, Douglas Co., were present spring - fall, left in the winter, and returned in the spring for several years (Silcock and Jorgensen 1998). Sporadic, introduced or escaped species. Builds its stick nests and lives in them year-round, hence nest-building is not synonymous with breeding (Spreyer and Bucher 1998).

Carolina Parakeet, Conuropsis carolinensis. Extinct. Seven reports. Only report of breeding is a statement: "Many of the young ones were taken from their nests by the boys and raised by hand for pets." (Furnas 1902). The above statement refers to McKissock Island in the Missouri River, where earlier Lt. G. K. Warren and F. V. Hayden collected specimens on 24/25 April 1856 (Swenk 1934). Three of the skins were sent to the USNMNH, \#4609, \#4612, and \#4614. Later \#4609 was transferred to UMMZ, and \#4612 was transferred to MCZ (VertNet 2018).

\section{Family Tyrannidae (Flycatchers)}

Ash-throated Flycatcher, Myiarchus cinerascens. Five reports. No nest records. First report: J. B. Burnett collected a set of 4 eggs near Nebraska City, Otoe Co. on 26 June 1907 (UNSM, Cat. \#ZM8555). The eggs of $M$. cinerascens are much less heavily marked than those of M. crinitus (Baicich and Harrison 1997).The above set eggs was compared to Great 
Crested Flycatcher eggs in the collection, cannot be distinguished from them, and are considered to be Great Crested Flycatcher eggs which were mistakenly identified ( $T$. E. Labedz, W. J. Mollhoff). First record: An agitated bird was noted carrying food on 28 June 2007. Later that day a pair of adults fed a begging fledgling, SW of Bushnell, Kimball Co. (Mollhoff et al. 2008). Territorial birds have again been found in the area since. The area is a mix of conifer woodland: limber pine Pinus flexilis, ponderosa pine Pinus ponderosa, Rocky Mountain juniper Juniperus scopulorum, and mixed-grass/shortgrass prairie on rocky slopes. Sporadic breeder in western Panhandle.

Great Crested Flycatcher, Myiarchus crinitus. Eighteen reports, three records. First record: E. Van Sant collected a set of 6 eggs on 5 June 1898 from Child's Point, Sarpy Co. (Shoemaker undated). M. A. Carriker, Jr., collected a set of 5 eggs in Otoe Co. (UNSM, Cat. \#ZM08549). On 8 June 1952 L. Seabury found a nest with eggs on Verdigre Creek, Antelope Co. (Seabury 1953). Common regular breeder, primarily in riparian woodlands. Usually nests in natural cavities or woodpecker holes. Four nests reported were 6 - $20 \mathrm{ft}(2-6 \mathrm{~m})$ high in trees. Two egg dates reported: 5 - 8 June. Nest-building reported 31 May - 16 June. Nests with young reported 28 June - 22 July. Two clutch sizes reported with 5 and 6 eggs.

Cassin's Kingbird, Tyrannus vociferans. Sixteen records. First record: The L. M. Gates family found a nest with 4 young high in a pine at Chadron State Park, Dawes Co. on 13 July 1944 (D. Gates undated). On 10 June 2000 I found a nest with 2 eggs SW of Bushnell, Kimball Co., and 2 more nests, with 2 and 5 eggs, also on that date, near Redington, Morrill Co. (Mollhoff 2001b). On 1 July 2001 I found 2 nests, each with 4 eggs, near Redington, Morrill Co. (Mollhoff 2004a).On 22 June 20022 nests with eggs were reported near Redington, Morrill Co. (Mollhoff 2004b). On 15/16 June 2003 I found 5 nests with eggs near Redington, Morrill Co. (Mollhoff 2005a). Rare regular breeder, limited to the Panhandle. Usually nests in the edge of pine woodland, but occasionally in windbreaks at farmsteads. Twenty-two nests reported $10-40 \mathrm{ft}(3-12 \mathrm{~m})$ high, usually in upper $1 / 3$ of tree. Fourteen egg dates: 9 June -1 July ( 9 - 16 June $=71 \%)$. Clutch sizes reported: 16 , usually 4 , sometimes 1 - 5, mean 3.2, mode 4 .

Western Kingbird, Tyrannus verticalis. Thirty-seven records. First record: W. L. Carpenter collected a set of 2 eggs on 13 June 1874 at Omaha, Douglas Co. (USNMNH, Cat. \#B17372). On 19 June 1890 N. S. Goss took a set of 3 eggs near Harrison, Sioux Co. (UKBI, Cat. \#95678). W. C. Smith collected 3 eggs on 20 June 1897 near Long Pine Brown Co. (SBM, Cat. \#43). J. C. Crawford took 6 eggs near Warbonnet Canyon, Sioux Co. on 27 June 1901 (UNSM, Cat. \#ZM08536). On 16 June 1901 M. A. Carriker, Jr., and M. Cary collected 5 nests, with 4, 5, 5, 6, and 6 eggs on Prairie Dog Creek, Sioux Co. (UNSM, Cat. \# ZM08538 - ZM08542). I. S. Trostler reported a nest with 4 eggs at Niobrara, Knox Co. (Trostler 1896). S. Moody reported a nest with 4 eggs at Greeley, Greeley Co. on 16 June 1968 (CNRCP). Abundant regular breeder statewide, nesting in scattered trees, woodland edge, and other open habitats. In urban areas it nests in open areas of shopping malls, parking lots, and sports fields. Nests placed well up in trees 6 $60 \mathrm{ft}(2-18 \mathrm{~m})$ high, frequently uses electric power circuit boxes, rarely places nest in cavity. Thirty-six egg dates: 1 June -16 July ( 2 - 29 June $=86 \%$ ). Clutches sizes reported: 37 , usually 4 eggs, sometimes 2 - 6 , mean 4.4 , mode 4 . One report is of mixed-species 
pair consisting of female Western Kingbird X male Scissor-tailed Flycatcher (Glandon 1945).

Eastern Kingbird, Tyrannus tyrannus. Fifty-three records. First record: N. S. Goss collected a set of 4 eggs at Lincoln, Lancaster Co. on 13 June 1890 (UKBI, Cat. \#95677). M. Pew took 4 eggs at Hebron, Thayer Co. on 21 June 1890 (CAS, Cat. \#4804). On 3 May 1892 L. Robbins collected 4 eggs at Saltillo, Lancaster Co. (UKBI, Cat. \#95675). On 14 June 1898 R. H. Wolcott took 4 eggs at Lincoln, Lancaster Co. (UNSM, Cat. \#ZM08530). On 20 July 1899 D. E. Jones collected 4 eggs in northern Garfield Co. (CM, Cat. \#E1154). On 26 June 1901 M. A. Carriker, Jr., collected 3 eggs on Jim Creek, Sioux Co. (UNSM, Cat. \#ZM08526). Abundant regular breeder statewide, nesting in grassland, woodland/grassland edge, swamps, homesteads, parks, and cemeteries. Nests placed 2.5 - $50 \mathrm{ft}(0.75-15 \mathrm{~m})$ up on shrubs, trees, idle farm machinery, fence posts, and wooden pallets. Seventy-five egg dates: 3 May - 20 July (5 - 26 June $=80 \%$ ). Clutch sizes reported: 53, usually 4 eggs, sometimes 3 - 5, mean 3.7, mode 4 .

Scissor-tailed Flycatcher, Tyrannus forficatus. Twenty-one reports, six records. First record: E. W. Glandon saw a nest with newly-hatched young $6 \mathrm{mi}$. SW of Stapleton, Logan Co. on 9 July 1944 (Glandon 1945). A nest with 3 eggs was found on 16 June 2007 at the Lincoln airport, Lancaster Co. (Carol Reitan, pers. comm.). A nest with 4 eggs was found on 27 June 2017 in McCook, Red Willow Co. (Angus Garey, pers. comm.). On 7 July 2017 a nest with 4 eggs was reported near Alexandria, Thayer Co. (Michelle Hurt, pers. comm.). I found a nest with 5 eggs on 8 June 2018 near Hebron, Thayer Co., and a second nest with 4 eggs that day near Alexandria, Thayer Co. Currently a rare, probably regular breeder south of Platte River, but with a low density population and few breeding records. Breeds in scattered trees in open grasslands, also in large parking lots, sports fields, and campgrounds. Nests may be low in trees or atop $100 \mathrm{ft}(30 \mathrm{~m})$ floodlights. Few egg dates due to inaccessibility of nests. Nine egg dates: 8 June - 7 July. Six birds reported in incubating posture: 13 June - 29 July. Nests with young reported 9 30 July. Fledged young noted by 8 July. Clutch sizes reported: 6 , usually 4 eggs, sometimes 5 , mean 4.3 , mode 4 . One report of mixed-species pair consisting of a male Scissor-tailed Flycatcher X a female Western Kingbird (Glandon 1945). Another report of a possible hybrid pair in Lancaster Co. in 1921, concerns a female Scissor-tailed Flycatcher with a nest (but no other Scissor-tailed Flycatcher was seen) and the presence of a Western Kingbird with which she was noted "...quarreling in a good natured way...." but does not mention any further interactions between the two (Swenk and Dawson 1921).

Western Wood-Pewee, Contopus sordidulus. Fourteen records. First record: On 13 July 1944 the L. M. Gates family found a nest at Chadron State Park, Dawes Co. with 4 young nearly ready to fly (D. Gates undated). There are reports of egg sets collected in Douglas, Sarpy, and Otoe counties in the 1890s. Definite identification required precise measurments of wing and beak, details which the collectors did not record on the cards. Ridgway $(1887,1900)$ and Coues $(1872,1903)$ were the best guides, both of which also use plumage darkness to help separate the two species, but that was a mark even the authors felt was not always reliable. Those early reports are not accepted. 
On 29 June 1966 L. Neeland found 2 eggs in a nest near Chadron, Dawes Co. (CNRCP). On 20 August 1995 W. F. Huser found a nest with 2 young in Monroe Canyon, Sioux Co. (Silcock 1995). On 7 July 2000 I found a nest with 3 eggs, and 2 more nests, each with 3 young, near Redington, Morrill Co. (Mollhoff 2001b). Uncommon regular breeder in the Panhandle, occasionally found during breeding season east to Cherry and Lincoln counties. Forty-eight nests reported were placed 8 - $48 \mathrm{ft}(2.5-15 \mathrm{~m})$ high on tree branches. Fourteen egg dates: 10 June - 15 July, no date clusters noted. Clutch sizes reported: 14, usually 2 - 3 eggs, sometimes 4, mean 3.1, mode 3.

Eastern Wood-Pewee, Contopus virens. Fourteen records. First record: On 24 June 1893 L. Skow collected a set of 3 eggs from a nest near 21st and Martha St., Omaha, Douglas Co. (WFVZ, Cat. \#215029). On 18 June 1895 J. R. Bonwell found a nest with 4 eggs at Nebraska City, Otoe Co. (WFVZ, Cat. \#215083). On 4 July 1894 L. Skow collected 2 eggs near Omaha, Douglas Co. (UNSM, Cat. \#ZM08584). On 6 June 1897 M. A. Carriker, Jr., took 3 eggs in Otoe Co. (WFVZ, Cat. \#49664). On 14 June 1897 E. West took 2 eggs at Omaha, Douglas Co. (UNSM, Cat. \#ZM08578). On 19 June 1898 M. A. Carriker, Jr., collected 3 eggs in Otoe Co. (UNSM, Cat. \#ZM08576). On 6 June 1899 J. Schmidt took 3 eggs near Albright, (Omaha), Douglas Co. (Shoemaker undated). On 17 June 1899 M. A. Carriker, Jr., took 3 eggs at Nebraska City, Otoe Co. (WFVZ, Cat. \#49665). On 15 June 1970 C. L. Cink reported a nest with 3 eggs at Sprague, Lancaster Co. (CNRCP). Common regular breeder, especially in eastern riparian woodlands, rarely found in the Panhandle. Ten nests found $7-40 \mathrm{ft}(2-12 \mathrm{~m}$ ) high in trees. Fourteen egg dates: 6 June -4 July ( 6 24 June $=93 \%)$. Clutch sizes reported: 14, usually 3, sometimes $2-4$, mean 2.9, mode 3 . Yellow-bellied Flycatcher, Empidonax flaviventris. Two reports. First report: A female with a brood patch was banded at Fontenelle Forest, Sarpy Co. on 1 June 1978 (Green 1978). Since the date falls within the spring migration window and description was not noted, its validity as a breeder may be suspect (Sharpe et al. 2001). The other report, published without details, a pair with young observed 8 July - 10 September 1978 near Bennet, Lancaster Co. (Bennett 1980). The observer's field notes were later found and reviewed, but the reviewer found they did not provide conclusive evidence (Mollhoff 2004b). It is not accepted.

Acadian Flycatcher, Empidonax virescens. Nine records. First record: L. Skow collected a set of 3 eggs from a nest on Child's Point, Sarpy Co. on 16 June 1895 (WFVZ, Cat. \#213431). On 8 June 1898 L. R. Sabine took 3 eggs at Child's Point, Sarpy Co. (WFVZ, Cat. \#49633). On 10 June 1898 F. H. Shoemaker collected 2 eggs near Albright (Omaha), Douglas Co. (UNSM, Cat. \#ZM08596). On 17 June 1898 E. Van Sant took 3 eggs at Albright, Douglas Co. (UNSM, Cat. \#ZM08597). On 26 June 1898 F. H. Shoemaker took 3 eggs at Child's Point, Sarpy Co. (UNSM, Cat. \#ZM08598). On 14 June 1899 R. B. Mullen collected 3 eggs at Turkey Buzzard, Sarpy Co. (Shoemaker undated). On 15 June 1899 R. Mullen took 3 eggs at Childs Woods (Fontenelle Forest), Sarpy Co. (UNSM, Cat. \#ZM08594). On 6 July 1899 R. Mullen collected 3 eggs at Child's Park, Sarpy Co. (UNSM, Cat. \#ZM08595). On 13 June 1901 F. H. Shoemaker took a photo (B0186) of a nest with 3 cowbird eggs, but no host eggs, at Child's Point, Sarpy Co. (Shoemaker undated). Rare regular breeder, mainly in riparian woodland along the Missouri River, to the Niobrara River, and west to Lancaster Co. Four nests reported $4-20 \mathrm{ft}(1-6 \mathrm{~m})$ high. Nine egg dates, 8 June - 6 July 
(8 - 26 June $=78 \%$ ). Clutch sizes reported: 9, usually 3 eggs, sometimes 2, mean 2.9, mode 3 . Brown-headed Cowbird parasitized $11 \%$ of reported nests.

Willow Flycatcher, Empidonax trailii. Twenty-four records. First record: N. S. Goss collected a set of 4 eggs on 3 July 1890 near Lincoln, Lancaster Co. (UKBI, Cat. \#95674). On 24 June 1893 I. S. Trostler took 4 eggs at Florence Lake, Omaha, Douglas Co. (WFVZ, Cat. \#49640). On 17 June 1894 B. E. Griffiths collected sets of 3 and 4 eggs at Cut-off (Carter) Lake, Omaha, Douglas Co. (UNSM, Cat. \#ZM06807, \#ZM08609). On 20 June 1894 G. W. Sabine took 4 eggs at Cut-off (Carter) Lake, Douglas Co. (WFVZ, Cat. \#213501), and another set of 4 eggs on 22 June 1894 (WFVZ, Cat. \#213442). On 30 June 1894, I. S. Trostler took two sets, each of 3 eggs, near Omaha, Douglas Co. (WFVZ, Cat. \#75069, \#213441). On 20 June 1895 L. R. Sabine collected 4 eggs at Child's Point, Sarpy Co. (WFVZ, Cat. \#213502). On 26 June 1898 R. H. Wolcott collected a nest with 3 eggs in a field near Wyuka Cemetery, Lincoln, Lancaster Co. (UNSM, Cat. \#ZM08603). On 23 June 1899 R. Mullen collected 4 eggs in Sarpy Co. (UNSM, Cat. \#ZM08612). On 28 June 1899 J. S. Hunter collected 4 eggs at Jamaica, Lancaster Co. (UNSM, Cat. \#ZM08601). J. T. Zimmer found a nest with 3 eggs at Lincoln, Lancaster Co. (Zimmer undated). Common regular breeder in shrubby riparian areas in much of the state, but rare in the Panhandle. Twenty-six nests were in: wild indigo (Amorpha fruticosa) (8), willow (Salix sp.) (6), wild plum (Prunus americana ) (5), dogwood (Cornus sp.) (3), other shrub (4). Nest heights reported were $2.5-8.5 \mathrm{ft}(0.75-2.5 \mathrm{~m})$. Forty-eight egg dates: 15 June - 16 July (15 June - 4 July $=75 \%)$. Clutch sizes reported: 24, usually 3 - 4 eggs, sometimes 1 2, mean 2.8, mode 4. Brown-headed Cowbird parasitized $4 \%$ of nests reported.

Least Flycatcher, Empidonax minimus. Twelve reports. No breeding records. Historic reports of breeding (Bruner 1896, 1901, Bruner et al. 1904) are not documented. Nearest breeding is in South Dakota (Tallman et al. 2002) and the Black Hills National Forest of Wyoming (Faulkner 2010). The species prefers mature deciduous forest with a shrubby understory. Most reports are of single birds, but during the second atlas project, "Probable" breeding activity was noted in Thurston, Dakota, and Knox counties. Any breeding season sightings (10 June - 15 July) should be investigated for evidence of breeding. Not proven to be a breeder at this time.

Cordilleran Flycatcher, Empidonax occidentalis. Seven records. First record: R. C. Rosche found a nest with 4 young in a crevice in Sowbelly Canyon, Sioux Co. on 20 July 1974 (Bennett 1975). On 21 June 2007 I photographed a nest with 4 eggs built in a rotted-out cavity nest in a pine snag in Monroe Canyon, Sioux Co. On 27 June 2008 I found another nest with 4 eggs in Sowbelly Canyon, Sioux Co. (Grier 2009). On 4 June 2008 I found a bird adding material to a nest on a bridge beam that already held one egg, near Crawford, Dawes Co. On 20 July 2011 I found a nest with 3 eggs in a rocky outcrop on East Hat Creek Road, Sioux Co., and on the same day found a second nest in a cavity in a boulder at Metcalf WMA, Sheridan Co. Rare regular breeder in the Panhandle, nesting in the canyons, especially in the Pine Ridge. Gradually expanding its range (Mollhoff 2016). Places nests mostly in crevices in the cliffs, but occasionally in rotted-out tree cavities or beneath bridges. Six egg dates: 14 June - 20 July, no notable date clusters. Clutch sizes reported: 7, usually 3 - 4 eggs, occasionally 1 , mean 3.1, mode 3 or 4 . Brown-headed Cowbird parasitized $14 \%$ of nests reported. 
Eastern Phoebe, Sayornis phoebe. Eighty records. First record: On 27 April 1889 N. S. Goss collected a set of 4 eggs near Lincoln, Lancaster Co. (UKBI, Cat. \#95679). On 12 May 1893 J. S. Pyfer collected 5 eggs at Odell, Gage Co. (CAS, Cat. \#7479). L. Skow collected 5 eggs at Omaha, Douglas Co., on 21 May 1893 (WFVZ, Cat. \#213216). On 18 May 1898 W. C. Smith took 3 eggs at Lincoln, Lancaster Co. (SBM, Cat.\#14). On 10 May 1899 W. Tout collected 5 eggs at McCool Junction, York Co. (Tout 1901). On 4 June 1900 J. C. Crawford took 5 eggs at West Point, Cuming Co. (UNSM, Cat. \#08560). On 15 May 1939 Glandon reported a nest with 5 eggs near Stapleton, Logan Co. (Glandon 1939). Abundant breeder, widespread in riparian habitats, decreasing westerly, in the Panhandle nests found only in the Pine Ridge. Eighty-six nest sites reported: bridge/culvert (64), buildings (13), hole in vertical dirt or rocky bank (8), abandoned car body (1). Ninety-four egg dates: 7 April - 7 July (23 April - 10 May = 30\%), (26 May - 16 June $=29 \%$ ). Other dates scattered. Usually double brooded, possibly triple brooded. Clutch sizes reported: 80 , usually 4 - 5 eggs, sometimes 1 - 6, mean 4.4, mode 5 . Brownheaded Cowbird parasitized $5 \%$ of nests reported.

Say's Phoebe, Sayornis saya. Twenty-six records. First record: G. Ohlein collected a set of 4 eggs near North Platte, Lincoln Co. on 10 May 1897 (WFVZ, Cat. \#74658). On 20 June 1901 M. A. Carriker, Jr., collected 5 eggs from a nest in an abandoned outhouse in Sioux Co. (UNSM, Cat. \#ZM08571). On 17 June 1912 L. M. Gates found 3 eggs in a nest near Mitchell, Scotts Bluff Co. (Swenk and Gates undated). On 9 May 1955 V. and B. Wright found a nest with 5 eggs near Fullerton, Nance Co. (Lueshen 1956). On 12 June $1955 \mathrm{H}$. R. Benckeser found a nest with 6 eggs at Ash Hollow, Keith Co. (Benckeser 1956). On 4 June 1955 W. Newell found a nest with 6 eggs near Alexandria, Thayer Co. (Chase 1956). Uncommon breeder, mostly in the southwest and Panhandle, rarely in the eastern third of the state. Forty nests placed in: buildings (17), dry cutbanks or rocky outcrops (14), or bridges/culverts over dry gullies (9). Thirty-eight egg dates: 10 May - 24 July, (10 - 24 May =24\%), (2 - 20 June =50\%). Double brooded. Clutch sizes reported: 26, usually 4 - 5 eggs, sometimes 1 - 6, mean 4.3, mode 5. Brown-headed Cowbird parasitized $8 \%$ of nests reported.

\section{Family Laniidae (Shrikes)}

Loggerhead Shrike, Lanius ludovicianus. One hundred six reports. First record: On 23 April 1892 N. S. Goss collected a set of 6 eggs from a nest at Havelock (Lincoln), Lancaster Co. (UKBI, Cat. \#95681). On 24 April 1893, Goss collected two sets, of 5 and 6 eggs, near Lincoln, Lancaster Co. (UKBI, Cat. \#95682, \#95686). W. Tout found 4 eggs near York, York Co. on 22 June 1897 (Tout 1901). E. West took 5 eggs on 12 June 1898 near Omaha, Douglas Co. (UNSM, Cat. \#ZM09028). On 10 June 1901 M. A. Carriker, Jr., took 4 eggs in the Prairie Dog Creek badlands, Sioux Co. (UNSM, Cat. \#ZM09025). Common breeder statewide, but steadily declining at least since inception of Breeding Bird Survey in 1966. Breeds in grasslands with mix of shrubs and scattered trees, nearly absent from croplands now. Nests usually in thorny or twiggy shrubs and trees, $2-20 \mathrm{ft}$ (0.75 - $6 \mathrm{~m}$ ) high. One hundred eight egg dates: 14 April - 17 July (15 May - 8 June $=63 \%)$. Clutch sizes reported: 62 , usually $5-7$, sometimes $2-4$, mean 5.8 , mode 6 . Sometimes double brooded. 


\section{Family Vireonidae (Vireos)}

Black-capped Vireo, Vireo atricapilla. Early lists suggest the possibility of breeding (Bruner 1896, 1901) but were later discredited by an undated note stating: "Mr. Skow states that his record of the black-capped vireo, as previously published, is to be regarded as doubtful." (Swenk 1887 - 1916). Not accepted as a breeder.

White-eyed Vireo, Vireo griseus. Five records. First record: E. Van Sant collected a set of 4 eggs from a nest $4 \mathrm{ft}$ up in a hazel bush at Albright, Douglas Co. on 12 June 1898 (UNSM, Cat. \#ZM09053). On 28 June 1898 F. H. Shoemaker collected a nest with 2 eggs, plus 3 cowbird eggs, at Albright, Douglas Co. (UNSM, Cat. \#09054). On 8 June 1901 F. H. Shoemaker took a photo (\#B197) of a bird on the nest at Albright, Douglas Co. (Shoemaker undated). M. A. Carriker, Jr., collected an undated set of 3 eggs in Otoe Co. (UNSM, Cat. \#ZM09052). Five nests reported, 1898 - 1901, but none since. All nests were found in Douglas and Otoe counties. Probably extirpated as a breeder. Four egg dates, 8 - 28 June. Five clutch sizes reported, usually 3 eggs, one set of 4 eggs. Brownheaded Cowbird parasitized $20 \%$ of reported nests.

Bell's Vireo, Vireo bellii. Thirty-nine records. First record: On 23 July 1887 F. Peterson collected a set of eggs at Omaha, Douglas Co. (MSU, Cat. \#OR5207M). I. S. Trostler took 4 eggs near Omaha, Douglas Co. on 9 June 1893 (CAS, Cat. \#5580). He took another egg there on 11 June 1893 (SBMNH, Cat. \#AV-26169). Also on 11 June 1893, Trostler took a second nest there with 4 eggs, plus a cowbird egg (FMNH, Cat. \#20777). On 3 June 1894 B. E. Griffiths took a nest with 4 eggs near Florence, Douglas Co. (UNSM, Cat. \#ZM09601). On 11 June 1898 Trostler took 4 eggs in Douglas Co. (UFMNH, Cat. \#51013). Common regular breeder, almost state-wide except rare in the Panhandle and Sandhills. Nests especially in riparian shrubs, but also in dry upland settings, or even in residential areas. Of forty nest heights reported, only two (5\%) were above $3.3 \mathrm{ft}(1 \mathrm{~m})$ up. Fifty-six egg dates: 9 May - 23 July (7 - 24 June $=64 \%)$. Clutch sizes reported: 39, usually 4 eggs, sometimes 2 - 5, mean 3.7, mode 4. Brown-headed Cowbird parasitized 13\% of nests reported.

Yellow-throated Vireo, Vireo flavifrons. Five records. First record: M. A. Carriker, Jr., collected a set of 3 eggs from a nest in the top of an apple tree in Nebraska City, Otoe Co. on 6 June 1897, as well as a set of 4 eggs there on 11 June 1898 (Carriker 1901). On 6 June 1900 R. Mullen took 4 eggs in Sarpy Co. (UNSM, Cat. \#ZM09046). On 24 May 2007 L. Einemann found a nest with 4 eggs near Lincoln, Lancaster Co. (Larry Einemann, pers. comm.). Rare regular breeder along the Missouri River, it now appears to be expanding upstream along the Niobrara and Elkhorn rivers, and other streams in SE part of the state. Most reports are from riparian woodland, with nests placed high up in the trees, but nests have also been reported in apple orchards. Four egg dates: 24 May - 11 June, but there is also a report of a nest with young on the extremely early date of 9 May (Callaway and Callaway 1939). Clutch sizes reported: 5, usually 4 eggs, sometimes 3 , mean 3.8, mode 4.

Blue-headed Vireo, Vireo solitarius. Two reports. First report: J. E. Stipsky reported a nest with 3 eggs, plus 1 Brown-headed Cowbird egg, on 1 July 1934 near Hooper, Dodge Co. (Stipsky 1934). The second report was also by Stipsky, at the same date and location. 
Other early reports have no documentation of nesting (Bruner 1896, Bruner et al. 1904). No documentation is available to verify these accounts. Since Swenk had these reports available but did not include them in his following updates, he must have been in doubt as to their accuracy. These reports are not accepted.

Plumbeous Vireo, Vireo plumbeus. Four records. First record: M. A. Carriker, Jr., found a nest with 4 eggs on 21 June 1900 in Warbonnet Canyon, Sioux Co. (UNSM, Cat. \#ZM09049). F. H. Shoemaker found a nest with 4 eggs on 20 June 1911 in Monroe Canyon, Sioux Co. (Shoemaker undated). J. Nichols found a nest in West Ash Creek canyon that held a single half-grown young on 8 June 2004 (Mollhoff 2005a). I found a nest in Sowbelly Canyon, Sioux Co. on 14 June 2008 that held 4 eggs, plus 2 cowbird eggs (Mollhoff 2016). Extremely rare regular, but local breeder, limited to Pine Ridge canyons. Nests reported have been placed in both pines and deciduous trees. Four egg dates are $15-21$ June. Clutch sizes reported: 3 , all reports are of 4 eggs, mean 4.0, mode 4. Brownheaded Cowbird parasitized $33 \%$ of the nests.

Warbling Vireo, Vireo gilvus. Five records. First record: W. L. Carpenter collected 2 eggs on 14 June 1874 from a nest at Omaha, Douglas Co. (USNMNH, Cat. \#B17350). M. A. Carriker, Jr., took 3 eggs in Otoe Co. 11 June, 1897 (UNSM, Cat. \#ZM09044). J. B. Burnett took 2 eggs at Nebraska City, Otoe Co. on 3 June 1908 (UNSM, Cat. \#ZM09045). J. T. Zimmer found a nest with 4 eggs on 9 June 1910 at Lincoln, Lancaster Co. (Zimmer undated). W. Tout found a nest with 4 eggs on 19 June 1947 near North Platte, Lincoln Co. (Tout 1947). Uncommon regular breeder, found statewide except in treeless areas. Nests usually placed well up in tree, five nest heights reported: one was $7 \mathrm{ft}(2 \mathrm{~m})$, the others were 20 - $40 \mathrm{ft}(6-12 \mathrm{~m}$ ) high. Seven egg dates: 3 - 19 June. Clutch sizes reported: 5 , usually 3 - 4 eggs, sometimes 2 , mean 3.0, mode 4 .

Red-eyed Vireo, Vireo olivaceus. Thirteen records. First record: H. R. Taylor collected a set of 3 eggs from a nest at Omaha, Douglas Co. on 1 June 1894 (WFVZ, Cat. \#223499). W. C. Smith took 5 eggs near Long Pine, Brown Co. on 15 June 1896 (SBM, Cat. \#1). F. H. Shoemaker took 3 eggs near Albright, Douglas Co. on 10 June 1898 (UNSM, Cat. \#ZM09041). J. B. Burnett collected 2 eggs near Nebraska City, Otoe Co. on 3 June 1908 (UNSM, Cat. \#ZM09045). On 9 June 1910 J. T. Zimmer took 4 eggs at Lincoln, Lancaster Co. (Zimmer undated). On 18 June $1899 \mathrm{~J}$. S. Hunter collected a nest with 3 eggs, plus 1 cowbird egg at Saltillo, Lancaster Co. (UNSM, Cat. \#ZM09038, \#ZM15242). On 12 June 1988 T. E. Labedz found a nest with eggs, which included 1 cowbird egg, at Gilbert-Baker WMA, Sioux Co. (Thomas Labedz, pers. comm.). Common regular breeder statewide, where riparian habitat is available. Fifteen nests were $3-37 \mathrm{ft}(1-11 \mathrm{~m})$ high. Sixteen egg dates: 23 May - 6 July (8 - 18 June $=67 \%$ ). Clutch sizes reported: 13, usually 3 eggs, sometimes 4 - 5, mean 3.2, mode 3. Brown-headed Cowbird parasitized 31\% of the nests.

\section{Family Corvidae (Ravens, Crows, Jays, Nutcrackers, Magpies)}

Pinyon Jay, Gymnorhinus cyanocephalus. Five records. First record: I observed a pair adding lining to a nest on 22 May 1999 in East Monroe Creek canyon, Sioux Co. A follow up visit on 11 June revealed 4 eggs and 2 young (Mollhoff 2000b). On 1 June 2001, I found a nest with 5 eggs SSW of Redington, Morrill Co. (Mollhoff 2001b). I found four nests with 
eggs SSW of Redington, Morrill Co., on 17 April 2006 (Mollhoff 2006). Extremely rare regular breeder, found only in the Pine Ridge and Wildcat Hills areas. Colonial breeder, each colony has its own territory, and nests only in selected spots within its territory. Three egg dates: 18 April, 1 and 11 June. Nests are built and eggs laid in April. June egg dates are second attempts. Clutch sizes reported: 5 , usually 4 - 5 eggs, sometimes 6 , mean 4.6, mode 4.

Blue Jay, Cyanocitta cristata. Forty records. First record: M. Penn collected two sets of 5 eggs from nests near Hebron, Thayer Co. on 10 May 1889 (WFVZ, Cat. \#215258, \#215261). N. S. Goss took 4 eggs on 25 May 1889, near Lincoln, Lancaster Co. (UKBI, Cat. \#95689). L. Skow took 6 eggs at Omaha, Douglas Co. on 15 May 1893 (WFVZ, Cat. \#215275). J. S. Pyfer took 5 eggs 19 May 1894 at Odell, Gage Co. (CAS, Cat. \#7641). B. F. Griffiths took 4 eggs 20 May 1894 at Omaha, Douglas Co. (UNSM, Cat. \#ZM08644). W. C. Smith took 2 eggs near Long Pine, Brown Co. on 17 June 1896 (SBM, Cat. \# 26). Abundant regular breeder statewide, wherever trees are available. Nests in riparian and upland woodlands, in residential neighborhoods, around farmsteads, and in parks. Thirty-five nests placed in trees 5 - $40 \mathrm{ft}(1.5$ - $12 \mathrm{~m})$ high. Fifty-six egg dates: 15 April - 20 July (12 May -6 June $=63 \%)$. Nests after 15 June are likely second attempts. Clutch sizes reported: 40, usually 4 - 5 eggs, sometimes 2 - 6, mean 4.1, mode 5 .

Clark's Nutcracker, Nucifraga columbiana. Ten reports. No nest records. First breeding record: On 17 May 1987, D. F. Tomback observed a begging fledged young being fed twice by an adult in Sowbelly Canyon, Sioux Co. (Tomback 1995). A second accepted record occurred 8 January - 3 June 1997, in Morrill, Scotts Bluff Co. It also resulted in a youngof-the-year bird (Mollhoff 1997a). Erratic breeder in the Panhandle following incursions of birds from the west.

Black-billed Magpie, Pica hudsonia. Twenty-two records. First record: S. J. Pickett collected 5 eggs from a nest in Wahoo, Saunders Co. on 2 May 1894 (MVZ, Cat. \#6316). W. C. Smith collected 1 egg near Long Pine, Brown Co. 6 June 1898 (SBM, Cat. \#19). On 19 June 1907 R. Heaton took 7 eggs near Curtis, Frontier Co. (UNSM, Cat. \#ZM08632). On 21 April 1921 A. M. Brooking took 5 eggs near Elwood, Gosper Co. (HM, Cat. \#04608). On 2 June1923 H. Harris took 6 eggs near Simeon, 22 mi SSW of Valentine, Cherry Co. (USNMNH, Cat. \# B40481). On 1 May 1924, V. Young took 8 eggs from a nest near Simeon, Cherry Co., and returned on 27 May 1924, to take another 8 eggs from the same nest (UKBI, Cat. \#74782, \#74784). Formerly common, now rare regular breeder, mostly in the Panhandle, but with isolated pockets at sites scattered across the state. When population was higher, sometimes appeared to be colonial breeder. Sixty-six nests reported, 5 - $50 \mathrm{ft}(1.5-15 \mathrm{~m})$ high. Nests placed in thorny thickets, or in trees, both deciduous and conifers. Thirty-one egg dates: 5 April - 19 June ( 1 - 27 May =68\%). Clutch sizes reported: 27, usually 5 - 7 eggs, sometimes 4 - 9, mean 6.8, mode 6 .

American Crow, Corvus brachyrhynchos. Fifty-seven records. First record:N. S. Goss collected 5 eggs on 31 March 1890 at Woodland (6 mi S of Raymond), Lancaster Co. (UKBI, Cat. \#95693). L. Skow took 4 eggs on 22 April 1894 at Bouyer Island, 12 mi N of Omaha, Washington Co., and wrote part of the description in his native Danish! (UNSM, Cat. \#ZM08682). M. A. Carriker, Jr., took 4 eggs on Fourmile Creek, near Nebraska City, Otoe Co. on 26 March 1898 (UNSM, Cat. \#ZM08652). A. S. Pearse took 4 
eggs at Lincoln, Lancaster Co. on 10 April 1899 (USNMNH, Cat. \#B29735). On 5 April 1900 R. H. Wolcott took 6 eggs near Denton, Lancaster Co. (UNSM, Cat. \#ZM08675). Abundant breeder statewide, except in treeless areas, nesting in remote or urban woodlands, parks, or rural homesteads. Nests are substantial, frequently used later by owls, and placed well up in trees, 20 - $53 \mathrm{ft}$ (6 - $16 \mathrm{~m})$. Sixty-five egg dates: 25 March - 27 May (28 March - 22 April =78\%). Early nests sometimes fail due to spring blizzards; late April and May nests are likely second attempts. Clutch sizes reported: 55, usually 4 - 6 eggs, sometimes 3 - 9, mean 4.9, mode 5.

Chihuahuan Raven, Corvus cryptoleucus. Four records, three of them documented. First record: A. M. Brooking was shown 2 young birds that had been taken from a nest between Axtell and Wilcox, Kearney Co. on 11 June 1944, and were kept as pets (Brooking 1944). Another nest in the same area held 5 eggs on 18 April 1947 (Brown 1947). A nest was reported without documentation, in Dundy Co. in 1971 (Cink 1977). A pair of birds and a nest with 5 young were reported from Hall Co. in 1976 by multiple observers, but follow- up visits raised possible questions as to the identity of the young (Coons 1976, Lemburg 1976, Editor 1976). Sporadic breeder. Now extirpated as a breeder.

Common Raven, Corvus corax. One record. Thomas Say commented as they were about to leave the Engineer Cantonment at Ft. Calhoun, Washington Co., and head up the Platte River, "[Corvus] corax - the young nearly able to fly, May 12, 1820." (Thwaites 1905). No other reports that indicate breeding. Extirpated from the state. He also noted the presence of Corvus corne (American Crow) separately (Thwaites 1905).

\section{Family Alaudidae (Larks)}

Horned Lark, Eremophila alpestris. Fifty records. First record: On 19 May 1890, M. Pew collected a set of 3 eggs near Hebron, Thayer Co. (CAS, Cat. \# 4847). A. S. Pearse took 3 eggs on 4 April 1896 in Gage Co. (USNMNH, Cat. \#29737). On 28 June 1901, L. Bruner found a nest with 3 eggs at Bruner Brothers Ranches near Swan Lake, Holt Co. (Bruner undated). L. M. Gates took 3 eggs on 27 June 1914 near Mitchell, Scotts Bluff Co. (UNSM, Cat. \#ZM08627). On 22 May 1980, B. L. Sage found a nest with 4 eggs at CLNWR, Garden Co. (CLNWR archives). Abundant breeder statewide, nesting on bare ground in areas with sparse vegetation, shortgrass prairie, bare fallow fields, and crop stubble in minimum-till agricultural fields. Seventy-seven egg dates: 17 March - 23 July (9 April - 26 May =34\%), (7 - 30 June =44\%). Double-brooded. Clutch sizes reported: 50, usually 3 - 4 eggs, sometimes 2, mean 3.3, mode 3. Brown-headed Cowbird parasitized $10 \%$ of nests reported.

\section{Family Hirudinidae (Swallows)}

Bank Swallow, Riparia riparia. Seventy-four records. First record: N. S. Goss collected a set of 6 eggs from a nest near Lincoln, Lancaster Co. on 18 May 1889 (UKBI, Cat. \#95701). On 31 May 1897, E. West took 5 eggs near Omaha, Douglas Co. (UNSM, Cat. \#ZM09010). On 6 June 1897, F. H. Shoemaker took 5 eggs at Gibson, Douglas Co. (UNSM, Cat. \#ZM09013). J. S. Hunter took 4 eggs at Lincoln, Lancaster Co., on 18 May 1898 (UNSM, Cat. \#ZM09009). On 21 June 2002, nest burrows with 4, 5, 5, 5, and 5 eggs were found in a blowout near Harrison, Sioux Co. (Mollhoff 2004b). Common regular breeder statewide, 
usually nesting in perennial stream banks, but in the more arid Panhandle, sometimes nesting in dry, hard-packed sand blowouts and road cuts. Colonial nester, commonly 20 - 50 nests per colony, but in large vertical loess riverbanks, colonies of 200 - 300 pairs have been reported. Nest burrows usually $20-40$ inches $(0.5-1 \mathrm{~m})$ deep. Seventy-eight egg dates: 18 May - 23 June (5 - 23 June =82\%). Clutch sizes reported: 74, usually 4 - 5 eggs, sometimes $3-6$, mean 4.5 , mode 4 .

Tree Swallow, Tachycineta bicolor. Fifty-nine records. First record: On 29 May 1889, G. A. Coleman collected 6 and 7 eggs from two nests in old woodpecker holes about $2 \mathrm{ft}$. above the water in a slough near Peru, Nemaha Co. (Coleman undated). On 7 June 1981, C. F. Zeilemaker found 6 eggs in each of two nests at CLNWR, Garden Co. (CLNWR, archives). On 3 June 1986, F. Andelt reported 6 eggs in a nest box near Crete, Saline Co. (CNRCP). On 26 May 1994, L. Brown found 6 eggs in each of 4 nest boxes at Twin Lakes WMA, Seward Co. (CNRCP). Abundant regular breeder statewide, with large increase recently, probably due to proliferation of bluebird boxes. Nests in natural cavities and woodpecker holes were $2-80 \mathrm{ft}(0.6-24 \mathrm{~m})$ high. Sixty-five nests were in: nest boxes (55), woodpecker holes (6), cavities (3), and an earth-mover exhaust pipe (1). Ninetyone egg dates: 6 May - 29 June (15 May - 9 June =81\%). Clutch sizes reported: 55 , usually 5 - 6 eggs, sometimes 3 - 10, mean 5.4, mode 5. Brown-headed Cowbird parasitized $2 \%$ of reported nests.

Violet-green Swallow, Tachycineta thallasina. Nine records. First record: On 25 June 1999, I found a nest with 5 eggs in an old Pygmy Nuthatch nest hole in Monroe Canyon, $5 \mathrm{mi}$ NW of Harrison, Sioux Co. (Mollhoff 2001b). Also on 25 June 1999, I found a nest with 6 eggs in West Ash Creek canyon (Mollhoff 2001b). A nest on West Ash Creek held 5 eggs on 22 June 2002. J. H. Winfrey found 5 eggs in each of two nest boxes on 24 June 2002 at WHNC, Scotts bluff Co. (Mollhoff 2004b). Rare regular breeder in forested Panhandle canyons. Nests placed in natural cavities, old woodpecker and nuthatch holes, cliff crevices, and bluebird boxes. Thirteen egg dates: 8 - 28 June. Clutch sizes reported: 9, usually 5 eggs, sometimes 6 , mean 5.2 , mode 5 .

Northern Rough-winged Swallow, Stelgidopteryx serripennis. Eleven records. First record: On 30 May 1895, D. R. Wallace collected a set of 4 eggs from a cavity in a stone near Saddle Creek city limits (Omaha), Douglas Co. (WFVZ, Cat. \#223063). W. C. Smith took 4 eggs near on 25 June 1897 Long Pine, Brown Co. (SBM, Cat. \#15). On 15 June 1984, W. J. Mollhoff found a nest with 4 eggs in a riverbank near Primrose, Boone Co. I found another nest with 3 eggs in Indian Cave, ICSP, Richardson Co. on 26 May 2002 (Mollhoff 2004b). On 30 June 2008, I found 2 nests, each with 5 eggs, in a sandy road cut near Gordon, Sheridan Co. Abundant regular breeder statewide, excavating its nests in stream banks, road cuts, rock outcrops, Sandhills blowouts, and even a pipe in a bridge abutment. Nest burrows usually $6-12$ inches $(15-30 \mathrm{~cm})$ deep. Sixteen egg dates: 20 May - 15 July (15 - 30 June $=75 \%$ ). Clutch sizes reported: 12, usually 4 - 5 eggs, sometimes 3 - 7, mean 4.8, mode 5 .

Purple Martin, Progne subis. Forty-three records. First record: A. S. Pearse collected a set of 4 eggs in Beatrice, Gage Co. on 25 June 1894 (USNMNH, Cat. \#B29746). On 29 May 1896, M. A. Carriker, Jr., took 3 eggs from a nest in the top of an arc-light, Otoe Co. (UNSM, Cat. \#ZM08981). On 7 June 1896, W. Tout found 4 eggs in a nest in the cornice of a 
storefront in York, York Co (Tout 1901). On 9 June 1900, M. H. Swenk took 5 eggs from a hole in a porch roof in Beatrice, Gage Co. (UNSM, Cat. \#ZM08982). On 29 May 1967, E. Bennett reported two nests with 2 and 5 eggs at Lincoln, Lancaster Co. (CNRCP). Uncommon regular breeder in the eastern half of the state, appears highly dependent on human-built and -maintained nest structures. One hundred seventy egg dates: 18 May - 30 June. Clutch sizes reported: 43, usually 5 eggs, sometimes 4 - 6, mean 4.9, mode 5.

Barn Swallow, Hirundo rustica. Eighty-six reports. First well documented record: W. C. Smith collected 2 eggs from a nest near Long Pine, Brown Co. on 16 June 1897 (SBM, Cat. \# 16). W. Tout reported a nest with 4 eggs near York, York Co. on 23 June 1897 (Tout 1901). M. A. Carriker, Jr., took 5 eggs from a deserted barn on Jim Creek, Sioux Co. on 26 June 1901 (UNSM, Cat. \#ZM08998). M. H. Swenk found 4 eggs in a bridge nest near Long Pine, Brown Co. (Swenk 1902a). H. Harris took an egg set near Simeon, Cherry Co. on 5 June 1922 (UKBI, Cat. \#7474). Abundant regular breeder statewide, nesting in buildings (especially occupied barns), bridges and culverts, and rarely on rock outcrops. Often nests in colonies. One hundred fourteen egg dates: 23 April - 15 August (28 May 15 June $=68 \%$ ). Sometimes double-brooded. Clutch sizes reported: 86 , usually $4-5$ eggs, sometimes 3 - 6, mean 4.6, mode 4 .

Cliff Swallow, Petrochelidon pyrrhonota. Sixty-one records. First record: On 25 May 1889, N. S. Goss collected 5 eggs from a nest near Lincoln, Lancaster Co. (UKBI, Cat. \#95700). W. C. Smith took 3 eggs near Long Pine, Brown Co., on 20 June 1897 (SBM, Cat. \#17). R. B. Mullen took 5 eggs in Sarpy Co. on 8 June 1899 (Shoemaker undated). G. Love took 3 eggs from a cliff in Keith Co. on 28 June 1913 (WFVZ, Cat. \#139693). L. M. Gates took 4 eggs from a bridge nest on 25 June 1915, at Scottsbluff, Scotts Bluff Co. (UNSM, Cat. \#ZM08988). M. J. Maryott took 4 eggs 1 July 1918 in Garden Co. (HM, Cat. \#02593). Abundant breeder statewide, nesting on bridges and culverts where available, but in the Sandhills where bridges are scarce, nests placed beneath the eaves of ranch buildings near lakes and ponds. Colonial nester with colonies of $10-1000$ s of pairs in a colony (Brown et al. 2012). Seventy egg dates: 4 May - 28 July (4 -25 June $=86 \%$ ). Clutch sizes reported: 61, usually 3 - 4 eggs, sometimes 2 - 6, mean 3.7, mode 4 .

\section{Family Paridae (Chickadees, Titmice)}

Black-capped Chickadee, Poecile atricapillus. Seventy-nine records. First complete record: On 5 May 1891 N. S. Goss collected 7 eggs near Roca, Lancaster Co. (UKBI, Cat. \#95704). L. J. Pickett took 7 eggs on 27 April 1892 at Wahoo, Saunders Co. (WFVZ, Cat. \#213647). I. S. Trostler took 2 eggs at Florence, Douglas Co. on 1 May 1897 (UFMNH, Cat. \#16296). On 29 April 1988 R. H. Wolcott took 6 eggs at Lincoln, Lancaster Co. (UNSM, Cat. \#ZM09237). M. A. Carriker,Jr., took 6 eggs at Otoe, Otoe Co. on 6 May 1899 (USNMNH, Cat. \#B45671). R. V. Mullen took 6 eggs from a fencepost at Child's Point, Sarpy Co. on 21 April 1900 (UNSM, Cat. \#ZM09223). Common regular breeder statewide, especially where riparian woodlands are present. Marked decline following the onset of West Nile virus about 2002, seems to be recovering somewhat at present. Nests in natural cavity, woodpecker hole, or self-excavated nest in rotten snag. Seventeen nests located, 3 inches - $30 \mathrm{ft}$ (0.1 - $9 \mathrm{~m})$ up. Thirty-three egg dates: 1 April - 30 May (21 April - 10 May 
$=67 \%)$. Clutch sizes reported: 79, usually 5 - 7 eggs, sometimes $4-9$, mean 6.1, mode 6 . Brown-headed Cowbird parasitized $1 \%$ of nests reported.

Tufted Titmouse, Baeolophus bicolor. Fifteen reports. No nest records. Probably a rare regular breeder along the Missouri River north to Burt Co., along the Platte River west to its confluence with the Elkhorn River. May also breed to Lancaster Co. and south to the Kansas border. A single probable egg date: a female with an active brood patch was banded at Fontenelle Forest, Sarpy Co. on 9 April 2016. On 12 April the same bird was seen entering and remaining in the nest cavity, and thought to be incubating (Rick Schmid, pers. comm.). Nest building activity has been noted 19 April - 19 June. Adults with begging young have been reported 12 June - 22 August. Obviously, much remains to be learned about the species.

\section{Family Sittidae (Nuthatches)}

Red-breasted Nuthatch, Sitta canadensis. Three records. First record: In May 1980, J. Manning found a nest at Steer Creek Campground, McKelvie National Forest, Cherry Co. On 2 June 1980, adults were tending young in the nest (Manning 1981). W. J. Mollhoff found a nest with 7 eggs on 31 May 1997 in Monroe Canyon, Sioux Co. (Silcock and Jorgensen 1997). Mollhoff found a nest with 5 eggs in West Ash Creek canyon Dawes Co. on 23 May 1999 (Mollhoff 2001b). Rare regular breeder in Pine Ridge, Wildcat Hills, central Niobrara River, and both McKelvie and Bessey Districts of Nebraska National Forest. Recently reported from Lancaster and Douglas counties. Breeds in mature conifer and/or deciduous woodland. May excavate own cavities, use cavities of other species, or natural cavities. Nest height recorded: $7-42 \mathrm{ft}(2-13 \mathrm{~m})$. Two egg dates reported: 23 and 31 May. Nest building reported 8 April - 18 June. Young in nest reported by 8 April. Fledged young noted by 17 July. Two clutch sizes reported: 5 and 7 eggs.

White-breasted Nuthatch, Sitta carolinensis. Thirteen records. First record: M. A. Carriker, Jr., collected a set of 6 eggs on 16 May 1897 in Otoe Co. (UNSM, Cat. \#ZM09212). On 29 April 1899 J. S. Hunter took 8 eggs at Lincoln, Lancaster Co. (UNSM, Cat. \#ZM09214). M. A. Carriker Jr., took 9 eggs in Otoe Co., on 6 May 1899 (UNSM, Cat. \#ZM09213). On 4 May 1907, J. B. Burnett took 6 eggs at Nebraska City, Otoe Co. (UNSM, Cat. \#ZM09215). On 23 May 1998, K. Bruning reported a nest with 7 eggs in a box sitting on his woodpile $12 \mathrm{mi}$ S of Crawford, Dawes Co. (Keith Bruning pers. comm.). Common regular breeder in the Pine Ridge, and in riparian woodlands east of the Panhandle. Usually nests in natural cavity, sometimes in nest box. Thirteen nests placed $2-30 \mathrm{ft}(0.75-9 \mathrm{~m})$ high, one in a nest box left sitting on a pile of firewood. Sixteen egg dates: 26 April - 23 May, no date clusters noted. Clutch sizes reported: 13, usually 6 eggs, sometimes $4-9$, mean 6.0, mode 6 .

Pygmy Nuthatch, Sitta pygmaea. Fifteen records. First well-documented record: Ifound a nest with 7 eggs in a pine snag in Monroe Canyon, near Harrison, Sioux Co., on 31 May 1997. Details of seven other active nests were included in that report (Mollhoff 1997b). On 23 May 1998, I found 10 eggs in a nest at Gilbert-Baker WMA, Sioux Co. On 22 May 1999, I found two nests with 8 and 9 eggs at Gilbert-Baker WMA, Sioux Co. On 19 May 2000, two nests with 6 and 7 eggs were found there (Mollhoff 2001b). On 22 May 2005 a nest with 7 eggs was found in Sowbelly Canyon, Sioux Co. (Mollhoff 2005b). Rare 
regular breeder in pine woodlands in the Panhandle. It may be extending its range eastward. Range closely tied to availability of extensive stands of ponderosa pine (Pinus ponderosa) with standing dead snags. Almost always excavates own nest cavity. Twentyfour nests placed $6-40 \mathrm{ft}(2-12 \mathrm{~m})$ high, up to where diameter of snag still permits a nest, 4.5 inches $(11 \mathrm{~cm})$. Sixteen egg dates: 10 - 31 May (19 - 31 May =94\%). Clutch sizes reported: 16, usually 6 - 7 eggs, sometimes 4 -10, mean 7.3, mode 7 .

\section{Family Certhiidae (Creepers)}

Brown Creeper, Certhia americana. Three records. First record: R. G. Cortelyou, with C. and E. Johnson, found a nest at Fontenelle Forest, Bellevue, Sarpy Co., on 26 May 1975 (Cortelyou 1975). On 9 July 1982, a nest with young was found at the TNC Niobrara Valley preserve (Mossman and Brogie 1983). A nest with young was found on 1 June 2002 on West Ash Creek, Dawes Co. (Mollhoff 2004b). Sporadic, or possibly extremely rare regular breeder in riparian deciduous and upland coniferous woodlands at both ends of the state. Nests are placed out of sight behind loose bark, making them very difficult to find or examine without destroying them, and are placed 6 - $36 \mathrm{ft}(2-11 \mathrm{~m})$ up, usually in dead snags. No egg dates reported. Nest building reported 7 April - 20 May. Nests with young reported 20 May - 9 July. No clutch sizes reported. Nests with two and four young have been reported.

\section{Family Troglodytidae (Wrens)}

Rock Wren, Salpinctes obsoletus. Six records. First record: M. A. Carriker, Jr., found a nest with 7 eggs in a vertical dirt bank on 24 June 1901 in Warbonnet Canyon, Sioux Co. (Carriker 1902). On 5 July 1901 Carriker took a set of 6 eggs at Warbonnet Canyon, Sioux Co. (UNSM, Cat. \#ZM09183). On 23 May 1936 W. Tout found a nest with 3 eggs south of North Platte, Lincoln Co. (Tout 1936). I found a nest with 3 eggs in a cavity of a boulder near Redington, Morrill Co., on 30 June 2001 (Mollhoff 2004a). On 24 July 2002 H. Hughson found a nest with 2 eggs on their ranch north of Scottsbluff, Sioux Co. (Mollhoff 2004b). Uncommon regular breeder in the Panhandle and southwest, placing nests in holes in the vertical dirt banks of gullies and road cuts, as well as cliffs and rocky outcrops. Eight egg dates: 16 May - 28 July (24 - 28 July =50\%). The late-July date cluster might indicate double broods. Clutch sizes reported: 6, usually 5 - 7 eggs, sometimes 2 3, mean 4.8, mode 6.

House Wren, Troglodytes aedon. Sixty-seven records. First record: On 16 June 1874 W. L. Carpenter found a nest with 7 eggs at Omaha, Douglas Co. (USNMNH, Cat. \#B17368). On 2 June 1894 A. Pyfer took 7 eggs at Odell, Gage Co. (CAS, Cat. \#8943). On 4 June 1898 R. H. Wolcott took 7 eggs at Lincoln, Lancaster Co. (UNSM, Cat. \#ZM09204). J. Schmidt took 6 eggs at Child's Point, Sarpy Co. on 9 June 1899 (UNSM, Cat. \#ZM09191). On 7 May 1934 H. R. Eschenburg took 7 eggs in Buffalo Co. (WFVZ, Cat. \#31036). Abundant regular breeder statewide, except in areas where trees or human structures are scarce. Builds its nests in almost any cavity in trees, buildings, nest boxes, farm machinery, rocky outcrops, woodpecker holes, etc. Ninety-three egg dates: 29 April - 28 July, with date clusters at 27 May - 12 June $=43 \%$, and 8 - 28 July $=30 \%$, suggestive of double 
brooding. Clutch sizes reported: 68, usually 6 - 7 eggs, sometimes 4 - 10, mean 5.6, mode 6.

Winter Wren, Troglodytes hiemalis. There is a single report in 2000, by C. Anderson "...of a territorial bird discovered singing near Tyler's Falls in the Ft Niobrara NWR, Cherry Co, between 23 May and 13 June..." (Silcock 2000a, 2000b). No other breeding activity was noted. This is the first summer report for the state, but the timing is correct for the expected breeding season at this latitude in Maryland (Ellison 2011). The current closest usual breeding area appears to be southeastern Wisconsin (Cutright et al. 2006). Not yet accepted as a breeder.

Sedge Wren, Cistothorus platensis. Twenty records. First record: On 24 June 1971 C. L. Cink found a nest with 5 naked young a few days old near Winnebago, Thurston Co. (Cink 1973). On 1 September 1988 P. A. Bedell reported a nest with 5 eggs at MICM, Hall Co. (CNRCP). On 28 August 1988 I found a nest with 3 young near Petersburg, Boone Co. (CNRCP). On 10 - 28 August 1989 P. A. Bedell reported 7 nests with eggs or young near Alda, Hall Co. (CNRCP). On 29 August 1992 Bedell reported a nest with 5 eggs at MICM, Hall Co. (CNRCP). On 26 August 1994 Bedell reported a nest with 2 pipped eggs and 3 young at Aurora, Hamilton Co. (CNRCP). 30 May - 28 July 2005 S. Sullivan found 8 nests with eggs at WCT, Hall Co. (CNRCP). Uncommon breeder in the eastern half of state. Nests in wet meadows, boggy areas, and sedges alongside marshes. Nests built in tussocks and sedge clumps $3-12$ inches $(7.5-30 \mathrm{~cm})$ above water. Thirty egg dates: 30 May - 1 September (10 - 29 August $=73 \%$ ). The high percentage of late summer nesting has led to the suspicion of a nesting elsewhere, and / or followed by an attempt here (Sharpe et al. 2001, Herkert et al. 2001). Clutch sizes reported: 11, usually 5 -6 eggs, sometimes 4 - 8, mean 5.5, mode 5. Brown-headed Cowbird parasitized $27 \%$ of nests reported.

Marsh Wren, Cistothorus palustris. Thirty-six records. First record: W. Tout found a nest with 1 egg, along with 4 other empty (dummy) nests at the York mill pond, York Co. on 10 July 1896 (Tout 1901). On 10 June 1897 W. C. Smith took 5 eggs near Long Pine, Brown Co. (SBM, Cat. \#5). On 15 July 1911 F. H. Shoemaker found eleven nests with eggs on Hackberry Lake, Cherry Co. (Shoemaker undated). On 9 June 1928 R. Overing found a nest with 5 eggs at Carter Lake, Douglas Co. (Swenk 1928). On 30 June 2006 I found six nests with 1, 3, 4, 4, 4, and 5 eggs near Merriman, Cherry Co. (Mollhoff 2006). Uncommon regular breeder in marshes almost state-wide, especially in the Sandhills. Thirty-six nests placed over water, in rushes (42\%), cattails (39\%), phragmites (11\%), and willows (8\%). Polygynous colonial breeder with one active nest, plus 4 - 5 'dummy' nests per male territory. Fifty-one egg dates: 26 May - 15 July (6 - 10 June =35\%), 30 June - 16 July $=53 \%)$. Bi-modal date distribution makes double brooding seem likely. Clutch sizes reported: 36, usually 3 - 5 eggs, sometimes 2 - 9, mean 4.2, mode 4.

Carolina Wren, Thryothorus ludovicianus. Six records. First record: Mrs. C. Groves found a nest with one young on 10 June 1928, on a ledge in a shed near the Republican River dam at Superior, Nuckolls Co. (Johnston 1928). On 4 May 1934 a pair began feeding young at workshop nest in Superior, Nuckolls Co. After the young fledged, had eggs in a second nest by 7 June (Johnston 1934). On 28 March 2005 the first egg was laid in a front-porch 
nest at A. Reyer's home in Bellevue, Sarpy Co. (Silcock 2005a). On 27 April 2007 a nest held 6 eggs in the same location as two years earlier (Silcock 2007). The Reyer front porch in Bellevue was again graced with a first egg on 14 April 2008, and D. Stage reported a nest with 5 eggs near Elkhorn, Douglas Co. on 15 April 2008 (Silcock 2008a). Rare regular breeder in the southeastern quadrant of the state. Nests in natural cavities, inside buildings, in plants on porches, or woodpiles. Ten egg dates: 28 March - 17 July, no date clusters, probably double or triple brooded. Clutch sizes reported: 6 , usually 4 5 eggs, sometimes 6 , mean 4.8 , mode 5 .

Bewick's Wren, Thryomanes bewickii. Three records. First record: S. Aughey reported finding a nest with young being fed by their parents near the Missouri River in Otoe Co. on 12 June 1875 (Aughey 1878). On 1 June 1952, D. and L. M. Gates found a nest with 4 young ready to fly, under the eaves of an old hen house at Peru, Nemaha Co. (Gates and Gates 1953). The other well-documented nest was found near West Point, Cuming Co., by L. Einemann, and held 6 eggs on 7 June 1969 (Larry Einemann, pers. comm.). The scattered, sporadic, reports are from the eastern and southern part of the state: along the Missouri River south of Douglas Co, northwest to West Point, Cuming Co., and west to Hastings, Adams Co. Nests have been reported from nest boxes, in buildings, and in residential areas. Nest-building has been reported by 16 April, and nests with young 1 June - 5 July. A brood of 4 young has been reported. Any breeding activity should be documented, further investigated, and reported.

\section{Family Polyoptilidae (Gnatcatchers)}

Blue-gray Gnatcatcher, Polioptila caerulea. Seven records. I. S. Trostler found two nests, with 3 and 4 eggs, in June 1900, near Bellevue, Sarpy Co., and later photographed one of the empty nests (Wallace 1901). On 10 June 2000 I found a nest with 4 eggs near Bushnell, Banner Co. On 11 June 2000 I found a nest with 4 eggs, and another nest with 2 eggs and 1 young near Redington, Banner Co. (Mollhoff 2001b). Another nest near Redington, Banner Co. held 2 eggs on 1 July 2001 (Mollhoff 2004a). On 29 June 2007 another nest with 3 young was found at Rocky Hollow, $\mathrm{N}$ of Kimball, Kimball Co. (Mollhoff 2008). This population has been increasing, rapidly expanding north along the Front Range of Colorado (Wickersham 2016). Uncommon regular breeder, formerly almost limited to the southeast, but since the late 1990s, breeding has been documented in the southwestern Panhandle and spread east along the southern border and north into the Pine Ridge (Mollhoff 2016). Eastern and southern birds breed in deciduous forest, while Panhandle breeders are usually found in pines. Fifteen nest heights reported 8 - $40 \mathrm{ft}$ (2.5 - $12 \mathrm{~m}$ ). Seven egg dates: 28 May - 17 June. Clutch sizes reported: 7 , usually 3 - 4 eggs, mean 3.4 , mode 3 .

\section{Family Turdidae (Thrushes)}

Eastern Bluebird, Sialia sialis. Fifty-eight records. First record: J. S. \& A. Pyfer collected a set of 5 eggs from a nest near Odell, Gage Co. on 14 April 1884 (CAS, Cat. \#9132). I. S. Trostler took 4 eggs near Cutoff (Carter) Lake, Douglas Co. on 21 June 1894 (WFVZ, Cat. \#228840). On 6 June 1895 W. C. Smith took 1 egg near Long Pine, Brown Co. (SBM, Cat. \#7). M. H. Swenk took 4 eggs near Beatrice, Gage Co. 12 July 1900 (UNSM, Cat. 
\#ZM09274). J. E. Stipsky noted 4 eggs at Hooper, Dodge Co. 25 May 1930 (Stipsky 1930). G. E. Hudson took 4 eggs at Roca, Lancaster Co. on 14 April 1934 (CRCM, Cat. \#76-20). Abundant regular breeder statewide, except where trees and nest boxes are absent. Breeds in woodland edge habitat and places nests in natural cavities, woodpecker or other holes, and nest boxes. Natural holes reported were 5 - $21 \mathrm{ft}$ (1.5 $6.5 \mathrm{~m}$ ) high. Sixty-two egg dates reported: 5 April - 15 July, dates spread equally 15 April - 15 July, due to multiple broods. Clutch sizes reported: 58, usually 4 - 5 eggs, sometimes 3 - 6, mean 4.5, mode 5. A report of hybridization between a female Eastern Bluebird paired with a male Eastern $x$ Mountain Bluebird was reportedly successful in raising two broods (Wilson et al. 1985, Wilson and Minyard 1986).

Western Bluebird, Sialia mexicana. One report. A set of eggs, reportedly of this species, was collected by M. A. Carriker, Jr., in Sioux Co. (UNSM, Cat. \#ZM09280) but may have been mislabeled at some point (Ducey 1988). The collector's original nest card was found recently. It was labeled Sialia arctica, which was the current name for Mountain Bluebird at that time. (See account below). It is not accepted.

Mountain Bluebird, Sialis currocoides. Twenty records. First record: M. A. Carriker, Jr., collected a set of 4 eggs from a cavity in a pine stub in Warbonnet Canyon (NW of Harrison), Sioux Co., on 10 July 1901 (UNSM, Cat. \#ZM09280). (See previous account of Western Bluebird). D. Gates found a nest with 4 young on 19 June 1966 at Chadron, Dawes Co. (CNRCP). On 12 May 1992 R. Green found a nest with 4 young in a picnic shelter at Red Willow Reservoir, Frontier Co. (Ruth Green, pers. comm.). Rare regular breeder in pine woodlands of the Pine Ridge and Wildcat Hills of the Panhandle. Places its nests in natural cavities, unoccupied nest cavities of other species in competition with nuthatches and swallows, and in nest boxes. Nests reported 9 - $28 \mathrm{ft}(3-9 \mathrm{~m})$ up. Twenty-one egg dates: 9 May - 10 July (9 May - 3 June $=86 \%$ ). May be double-brooded. Clutch sizes reported: 20, usually 4 - 5 eggs, sometimes 2 - 6, mean 4.7, mode 4 or 5). (See the report of a successful hybrid nesting with Eastern Bluebird in that account above.) Brown-headed Cowbird parasitized 15\% on nests reported.

Townsend's Solitaire, Myadestes townsendii. Five records. First record: On 25 May 1900 J. S. Hunter and M. Cary collected a set of 4 eggs from a nest inside a burned tree near the bottom of a dry canyon in the Pine Ridge, Sioux Co. (UNSM, Cat. \#09244). A second nest was found nearby on 27 May 1900, placed in a hole in an earthen bank, but it was empty, and the eggs were found inside a nearby bullsnake (Pituophis sayi) (Crawford 1901). On 18 July $1948 \mathrm{H}$. Benckeser found an adult with one young near Ogallala, Keith Co. (Benckeser 1948). On 20 July 1979 Dr. S. Longfellow, with his students, found an adult with an immature in Monroe Canyon, Sioux Co. (Fickel 1979). On 31 May 1986 R. C. Rosche reported a nest with eggs in East Hat Creek, Sioux Co. (Sharpe et al. 2001). In the Black Hills of South Dakota, eggs have been reported 17 May - 18 July, with fledged young 27 July, and migration away from the Black Hills as early as 13 September (Tallman et al. 2002). Sporadic breeder in the western Pine Ridge. Two nests, each with four eggs. Any birds found in the breeding season (mid-May - mid-July) should be investigated for evidence of breeding.

Swainson's Thrush, Catharus ustulatus. Eight reports. One record: R. C. Rosche found a nest with a young bird nearly ready to fledge on 12 August 1973 in West Ash Creek canyon 
8 mi southeast of Crawford, Dawes Co. (Rosche 1974, CNRCP). Earlier, on 17 June 1938, G. E. Hudson collected a female in NW Sioux Co., in Squaw Canyon, with "... ovaries [that] were enlarging indicating possible breeding." (Hudson 1939). On 8 June 2004 I found a singing male, defending a completed, empty nest in West Ash Creek, Dawes Co. (Mollhoff 2005a). Sporadic breeder in moist, cool canyon floors in the Pine Ridge. Territorial birds are reported occasionally (Mollhoff 2001b, 2005a, 2005b). Any birds demonstrating breeding activity during the breeding season (10 June - 31 August) should be investigated.

Hermit Thrush, Catharus guttatus. One report. "Outside the mountains of Colorado the most southern breeding point on record is Alda, Nebr. (Lat. $40^{\circ} 53^{\prime}$ ), from which place Mr. F. $W$. Powell writes that he found no nest, but saw the old birds feeding young which were too small to fly." (Cooke 1888). Bruner accepted this report in his publications of 1896 (Bruner 1896), and again in 1901 (Bruner 1901), but in 1904, the authors stated: "The breeding record from Alda by F. W. Powell (Bull 2. Div. Orn. p. 287) was probably a mistake." (Bruner et al. 1904). The record has not been accepted since.

Wood Thrush, Hylocichla mustelina. Forty records. First record: On 25 May 1889 N. E. Goss collected a set of 4 eggs on Salt Creek, Lincoln, Lancaster Co. (UKBI, Cat. \#95713), and a second set along Stevens Creek, Lancaster Co. 25 May 1891 (UKBI, Cat. \#95712). On 26 May 1892 L. Robbins collected 5 eggs near Jamaica, Lancaster Co. (UKBI, Cat. \#95715). On 28 May 1893 L. Skow took 4 eggs on 14th St., Omaha, Douglas Co. (WFVZ Cat. \#227690). On 10 June 1894, B. E. Griffiths took 3 eggs at Child's Point, Sarpy Co. (UNSM, Cat. \# ZM09254). E. Van Sant took 3 eggs on 23 May 1897 at Gibson, Douglas Co. (UNSM, Cat. \#ZM09251). On 31 July 1901 W. Tout took 4 eggs on the Blue River, near McCool Junction, York Co. (Tout 1901). Rare regular breeder in eastern third of the state, found especially in riparian woodlands, but numbers are declining. Thirty-seven nests were 4 - $20 \mathrm{ft}(1.2$ - $6 \mathrm{~m})$ high [4 - $10 \mathrm{ft}(1.2$ - $3 \mathrm{~m})=81 \%]$. Fifty egg dates: 13 May 31 July (25 May - 25 June $=78 \%$ ). May be double brooded. Clutch sizes reported: 40, usually 4 eggs, sometimes 2 - 5, mean 3.5, mode 4. Brown-headed Cowbird parasitized $35 \%$ of reported nests.

American Robin, Turdus migratorius. One hundred eight records. First record: On 26 May 1893 L. Skow collected 4 eggs in Omaha, Douglas Co. (WFVZ, Cat. \#228179). W. C. Smith took 1 egg near Long Pine, Brown Co. 10 May 1896 (SBM, Cat. \#36). On 4 May 1899 R. H. Wolcott took 4 eggs on Salt Creek, Lancaster Co. (UNSM, Cat. \#ZM09270). J. T. Zimmer took 4 eggs at Lincoln, Lancaster Co. 11 June 1910 (Zimmer undated). R. E. Dodge took 3 eggs at Nickerson, Dodge Co. 20 April 1911 (HM, Cat. \#02293). D. Teachenor took an egg set at Simeon, Cherry Co. 25 May 1925 (UKBI, Cat. \#75039). Abundant regular breeder, nests statewide wherever trees or human habitations are found. Builds nests on human structures or in trees, $2-55 \mathrm{ft}(0.6-17 \mathrm{~m})$ up [2 - $20 \mathrm{ft}$ $(0.6-6.0 \mathrm{~m})=95 \%$ of nests]. One hundred forty- six egg dates: 12 April -8 July (26 April 6 May = 36\%), (10 - 23 May = 32\%), (25 May - 16 June =16\%). Multiple broods. Clutch sizes reported: 106, usually 4 eggs, sometimes 2 - 5, mean 3.6, mode 4. 


\section{Family Mimidae (Mockingbirds, Thrashers)}

Gray Catbird, Dumtella carolinensis. One hundred sixteen records. First record: I. S. Trostler collected a set of 4 eggs near Cut-off Lake (Carter Lake), Omaha, Douglas Co. on 4 June 1893 (WFVZ, Cat. \#226204). B. E. Griffiths took 3 eggs at South Omaha, Douglas Co. on 20 May 1894 (Shoemaker undated). J. A. Dickenson took 4 eggs 1 June 1896 near Gresham, York Co. (WFVZ, Cat. \# 226203). W. C. Smith took 2 eggs near Long Pine, Brown Co. 15 June 1897 (SBM, Cat. \#9). M. A. Carriker, Jr., took 5 eggs in Otoe Co. on 1 June 1898 (WFVZ, Cat. \#101538). D. H. Leavitt took an egg set at Omaha, Douglas Co. on 25 May 1919 (MCZ, Cat. \#355310). Abundant regular breeder in the east, decreasing westerly to the Panhandle, where it is rare. Nests in shrubs and shrubby woodland edge habitat. One hundred thirty-two nest heights reported: 2 - $13 \mathrm{ft}(0.6-4 \mathrm{~m})$ high, with $95 \%$ reported below $9 \mathrm{ft}(3 \mathrm{~m})$. One hundred twenty-nine egg dates: 20 May - 8 August (28 May - 2 July =86\%). May be double brooded. Clutch sizes reported: 116 , usually $3-4$ eggs, sometimes 2 - 5, mean 3.7, mode 4. Brown-headed Cowbird parasitized 2\% of nests.

Curve-billed Thrasher, Toxostoma curvirostre. Seven reports. One record: A male that occupied a site for 6 years before vanishing, was repeatedly observed singing, nest-building and feeding American Robin and Common Grackle nestlings (Silcock 2003a). On 6 September 2003, following the first summer of his occupation, J. Gubanyi reported "...a brood of otherwise normal Brown Thrashers [which included] one with a gray head and back." (Silcock 2003b), thus making it seem possible/likely that the male Curve-billed Thrasher mated with a female Brown Thrasher to produce a single hybrid. A similar situation has been reported in Florida (Cavitt and Haas 2000).

Brown Thrasher, Toxostoma rufum. One hundred thirty-two records. First record: Founding member of the AOU, H. W. Henshaw, collected 3 eggs at Omaha, Douglas Co. on 4 June 1874 (USNMNH, Cat. \#B17345), and 2 more eggs at Omaha, 12 June 1874 (USNMNH, Cat. \#B17344). N. E. Goss took 5 eggs at Lincoln, Lancaster Co. on 12 May 1893 (UKBI, Cat. \#95721). J. A. Dickenson took 5 eggs at Gresham, York Co. on 20 May 1894 (WFVZ, Cat. \#226427). B. E. Griffiths took 2 eggs at Florence Lake, Omaha, Douglas Co. 17 June 1894 (UNSM, Cat. \#ZM09172). J. S. Hunter took 5 eggs at Lincoln, Lancaster Co. 18 May 1898 (UNSM, Cat. \#ZM09164). Abundant regular breeder in woodland edge, fenceline thickets, parks, homesteads, and residential areas statewide. Reports of 136 nests ranged from zero to $15 \mathrm{ft}(0.0-4.5 \mathrm{~m})$, with $99 \%$ of nests below $10 \mathrm{ft}(3 \mathrm{~m})$. One hundred seventy-eight egg dates: 10 May - 22 July (16 May - 17 June $=79 \%$ ). Multiple broods. Clutch sizes reported: 132, usually 3 - 5 eggs, sometimes 6, mean 4.0, mode 4. Brown-headed Cowbird parasitized $6 \%$ of nests reported. Possible hybrid with Curvebilled Thrasher, noted in that account.

Sage Thrasher, Oreoscoptes montanus. Six reports. No nests reported. On 20 May 1900 M. Cary and M. A. Carriker ..."found it nesting within a half mile of the Nebraska line in Wyoming ..." (Bruner et al. 1904). On 18 June 2009, C. Klaphake found an adult carrying food, presumably to feed young, in Kimball Co. (Silcock 2009b). A bird was noted at Toadstool Geologic Park, Sioux Co. 23 May 2016, and one was seen again 1 June, and an apparent family group of 4 found there on 9 June 2016 (Silcock 2016). In South Dakota, nests with 
eggs have been reported 17 June - 23 July (Tallman et al. 2002). Birds observed 20 May 20 July should be investigated as possible breeders.

Northern Mockingbird, Mimus polyglottos. Six records. First record: J. S. Hunter collected 4 eggs near Saltillo, Lancaster Co. on 22 June 1899 (UNSM, Cat. \#ZM09143). R. W. Dawson and C. E. Mickel noted a nest with 3 eggs on 30 June 1916, near Mitchell, Scotts Bluff Co. (Mickel and Dawson 1916). C. L. Cink noted a nest with 3 eggs on 5 June 1970 at Hallam, Lancaster Co. (Cink 1971). W. A. Schleicher reported a nest with 5 eggs on 15 June 1972, near Grand Island, Hall Co. (CNRCP, \#2159). N. G. Johnson reported a double brood with eggs on 4 July, and again 29 July 1977, at Bennet, Lancaster Co. (CNRCP \#2753, \#2755). Uncommon regular breeder, most common along the southern border, decreasing northerly. Eight nests placed low in trees and shrubs, $2-6 \mathrm{ft}(0.6-2 \mathrm{~m})$ high. Fourteen egg dates: 5 June - 19 August, no date clusters noted. Nest-building has been reported 29 May - 8 August. Double brooded. Clutch sizes reported: 9, usually 3 - 4 eggs, sometimes $2-5$, mean 3.9 , mode 4 . The paucity of reports prior to 1930 , and the increase after 1970 indicate a range expansion/population increase after mid-century.

\section{Family Sturnidae (Starlings)}

European Starling, Sturnus vulgaris. Twenty-seven reports. First record: On 18 May 1832 G. E. Hudson salvaged a young bird that was killed at a nest at C. R. Weigers farm near Western, Saline Co. (Swenk 1932). Not surprisingly, little interest has been shown this invasive pest. I took 4 eggs from a nest in an unused air duct at Ashland, Saunders Co. on 1 May 1997, another set of 4 eggs on 14 May, another 3 eggs on 28 May, and a final set of 3 eggs on 12 June 1997, each set being taken when completed. On 2 May 1998, the site held 4 eggs, and held 3 young on 17 May. A second clutch of 4 eggs was laid by 7 June. The same site held 5 eggs on 28 April 2000. An old woodpecker hole in a snag near Gordon, Sheridan Co. held 4 eggs 31 May 2007, while a nearby hole held 5 eggs on 8 June 2007. Abundant introduced cavity nester, initially in and near human habitations, but since the first NBBAP in the mid-1980's numbers have increased and birds have expanded into wooded habitats in remote areas and aggressively usurped all nest cavities of adequate size. Nest-building noted by 10 March. Twenty egg dates: 26 April 14 June, no date clusters noted. Clutch sizes reported: 9, usually 4 eggs, sometimes 3 5, mean 4.0, mode 4. Multiple broods.

\section{Family Bombycillidae (Waxwings)}

Cedar Waxwing, Bombycilla cedrorum. Four records. First record: R. Mullen collected a set of 5 eggs in Douglas Co. on 4 June 1901 (UNSM, Cat. \#09015). D. Geesaman reported a nest with 4 young at Ft. Calhoun, Washington Co. on 16 July 1945 (Wilson 1945). L. McDaniel noted fledged young at VNWR, Cherry Co. on 28 July 1984 (Len McDaniel, pers. comm.). I found 3 eggs and a chick in a nest at Gilbert-Baker WMA, Sioux Co. 21 June 2007 (Mollhoff 2008). Little detailed breeding data due to unpredictable habits and locations. Common regular breeder in a variety of habitats state-wide, often nesting near water, also residential areas or rural homesteads. Twelve nests placed in trees 6 $30 \mathrm{ft}(2-9 \mathrm{~m})$ high. Nest-building reported 26 May - 15 July. Ten egg dates: 4 June - 25 
July (8 - 22 June $=70 \%$ ). Clutch sizes reported: 4, usually 4 eggs, sometimes 5 , mean 4.3, mode 4 . Sometimes double brooded.

\section{Family Passeridae (Eurasian Sparrows)}

House Sparrow, Passer domesticus. Twenty-two records. First record: On 4 May $1892 \mathrm{~L}$.

Robbins collected a set of 4 eggs from a nest at Roca, Lancaster Co. (UKBI, Cat. \#95750).

G. W. Sabine took 5 eggs at Omaha, Douglas Co. on 26 May 1894 (UNSM, Cat. \#ZM09138). On 31 May 1897 J. C. Crawford Jr., took 5 eggs at West Point, Cuming Co. (UNSM, Cat. \#ZM09131). On 7 June 1909 J. T. Zimmer took 4 eggs at Lincoln, Lancaster Co. (Zimmer undated). A. M. Brooking took 7 eggs at Inland, Clay Co. on 19 February 1927 (HM, Cat. \#02202). Abundant regular introduced breeder around human structures statewide. Nests usually placed in buildings, nest boxes, old swallow, robin, and phoebe nests, and other cavities, but sometimes builds own nests in trees. Eggs have also been found in active nests of Eastern Bluebird and House Finch. Sometimes appears to be colonial in Barn and Cliff Swallow colonies or in buildings. Forty-three egg dates: 19 February - 17 July (23 April - 16 May =51\%). Multiple broods. Clutch sizes reported: 22, usually 3 - 5 eggs, sometimes 2 - 7, mean 4.4, mode 5 .

\section{Family Fringillidae (Grosbeaks, Finches, Siskins, Goldfinches)}

Evening Grosbeak, Coccothraustes vespertinus. Five reports. No nest records. First report of breeding activity: "The Western Evening and Black-headed Grosbeaks both have nested here in town [Chadron]." but no details were provided (Blinco 1946). In 1989 the Rosches reported, "A pair of Evening Grosbeaks, noted coming daily to a feeder, was accompanied by young in late June - the most definitive evidence of nesting reported from Nebraska to date (RCR, DJR)." (Grzybowski 1989b). Unstated is the assumption that the feeder was at the Rosche's home in Chadron, Dawes Co. Despite being secretive during the breeding season, there are several documented breeding records in the Black Hills (Tallman et al. 2002), and in the mountains of Wyoming (Faulkner 2010). The species may be a sporadic breeder in the Pine Ridge following winter irruptions.

House Finch, Haemorhous mexicanus. Forty-two reports. First record: After seeing a family on 18 July 1926, on 6 August, Mrs. J. W. Hall found a pair of adults with 5 young in a canyon south of Mitchell, Scotts Bluff Co. (Hall 1926). Mrs. Olson noted a nest with 4 eggs in Scotts Bluff Co. on 7 May 1955 (Olson 1956). V. Coons noted a nest with 3 young in Grand Island, Hall Co., 26 May 1983 (Coons 1983). On 28 April 1997 I found 5 eggs in a nest at Ashland, Saunders Co. In rural western Banner Co., only a few miles from where R. H. Wolcott and F. H. Shoemaker first found the species in Nebraska on 2 August 1911 (Shoemaker undated), I found the only 'wild' nest so far reported on 6 June 2008. It was in a ponderosa pine sapling at the woodland edge and held 4 eggs. Now a common regular breeder statewide, but still rare in its original conifer woodland habitat. It bred initially in conifer woodlands of the Panhandle, but spread eastward along with wintertime bird feeders to Hall Co. in the 1970s, and met the westward-expanding transplanted eastern population somewhere in eastern Nebraska in the 1980s. Reported initially in residential areas with bird feeders, now also found at remote cemeteries and parks with human-planted conifers. Shows strong preference for nesting in conifers, 
especially ornamental blue spruce (Picea pungens), but also in open buildings, decorative ornaments on porches, and other sheltered spots. Fifty nests placed $4-16 \mathrm{ft}$ $(1.5-5 \mathrm{~m})$ high, [4 - $10 \mathrm{ft}(1.5-3 \mathrm{~m})=82 \%]$. One hundred six egg dates: $14 \mathrm{March}-7 \mathrm{July}$ (25 April - 18 May =65\%). Multiple broods. Clutch sizes reported: 42, usually 4 - 5 eggs, sometimes $3-7$, mean 4.2, mode 5. Brown-headed Cowbird parasitized 19\% of nests reported.

Cassin's Finch, Haemorhous cassinii. Four reports. No nests reported. Only confirmed breeding in the state: R. C. and D. J. Rosche, observed a female feeding 2 recently-fledged young, which were capable of only short flights from tree to tree, on 25 July 1980 (Rosche 1982). During NBBAP II, 'Probable' breeding behavior was reported on several occasions in western Kimball Co. (Mollhoff 2016). Sporadic breeder in conifers in the western Panhandle. Breeding season observations, 10 May - 31 July, should be investigated to document possible breeding.

Red Crossbill, Loxia curvirostra. Three records. First record: N. F. Joyner found a nest with 2 eggs in a park in Broken Bow, Custer Co. on 20 March 1920 (Swenk 1921). On 28 March 1920 M. Greenleaf and W. Marsh noted a male feeding a female on a nest in Elmwood Park, Omaha, Douglas Co. (Swenk 1921). R. C. Rosche reported a nest with eggs on 24 March 1974, and young on 5 April (Rosche 1982). Rare regular breeder in the Panhandle, with reports from conifer forests in the Sandhills, and scattered reports following irruptions elsewhere. Successful breeding is dependent on an adequate crop of pine cones (Pinus ponderosa), which is highly cyclical due to rainfall. Young have been noted in the nest by 26 February and fledged young by 22 April. Three egg dates: 20 - 28 March. A clutch size of 2 eggs was recorded with the first record, but that was an unsuccessful nest that was destroyed in a storm. Although young have been reported occasionally, there is a dearth of detailed information from the pine woodlands where it is most common, and much remains to be learned about this unpredictable wanderer.

Pine Siskin, Spinus pinus. Twelve records. First record: J. E. Wallace collected a nest with 3 eggs, plus one cowbird egg, on 14 May 1904 at Child's Point, Sarpy Co. (Swenk 1929). R. W. Dawson found a nest with 1 young on 6 May 1911 at Lincoln, Lancaster Co. (Swenk 1929). C. E. Mickel took 4 eggs on 18 April 1917 at Lincoln, Lancaster Co. (UNSM, Cat. \#ZM08824), and another 3 eggs on 22 April 1917 at the same location (UNSM, Cat. \#ZM08825). N. Rowe noted a nest with 4 eggs on 4 May 1938 at Hastings, Adams Co. (Rowe 1938). A. J. Schock detailed a nesting attempt in 1983 at Wayne, Wayne Co. (Schock 1983). Rare regular breeder, with nest reports coming from all over the state following winter irruptions. Small-seeded conifers such as spruce (Picea sp.) and Douglas-fir (Pseudotsuga sp.) are important as food souces and nest sites. They are planted as ornamentals in parks, cemeteries, and residential areas across the state and account for the bulk of our records. However, there are no nest records from the Pine Ridge. Twenty-seven egg dates: 25 March - 23 May, no date clusters noted. Clutch sizes reported: 11, usually 3 - 4 eggs, mean 3.5, mode 3. Brown-headed Cowbird parasitized $36 \%$ of nests reported.

Lesser Goldfinch, Spinus psaltria. Five reports. No nest records. First confirmed breeding record: On 19 June $2010 \mathrm{~K}$. DeLara and A. Kenitz observed a pair delivering food to "cheeping" young inside a bush (Silcock 2010). Sporadic breeding, increasing in the past 
decade. Most habitat reports are of shrubs. Birds found during the breeding season (15 June - 15 August) should be investigated for evidence of breeding.

American Goldfinch, Spinus tristis. Eighty records. First record: On 18 August 1895 L. Skow collected a set of 5 eggs from a nest at Hardwood Lake, Douglas Co. (WFVZ, Cat. \#119264). E. West took 5 eggs at Omaha, Douglas Co. on 25 July 1897 (UNSM, Cat. \#ZM08815). W. Tout noted 2 eggs and 2 young near York, York Co. 31 July 1897 (Tout 1901). W. C. Smith took 2 eggs near Long Pine, Brown Co. 2 August 1897 (SBM, Cat. \#2). J. T. Zimmer took 5 eggs and a cowbird egg 23 July 1913 at Geneva, Fillmore Co. (Zimmer undated). Abundant regular breeder statewide, most commonly breeding in shrubby riparian habitats. Fifty-three nests were placed in dogwood (Cornus sp.) and other shrubs, large forbs, and small trees $3-13 \mathrm{ft}(1-4 \mathrm{~m})$ high, [3 - $8 \mathrm{ft}(1.0-2.5 \mathrm{~m})$ $=83 \%]$. Three hundred twenty egg dates: 23 May -10 September. Bi-modal distribution clusters: (17 July - 5 August $=59 \%$ ) and ( 8 August -1 September $=31 \%$ ) may indicate double brooding. Clutch sizes reported: 80 , usually 4 - 5 eggs, sometimes $3-7$, mean 4.6, mode 5 . Brown-headed Cowbird parasitized $16 \%$ of nests reported.

\section{Family Calcariidae (Longspurs)}

Chestnut-collared Longspur, Calcarius ornatus. Three records. First record: On 30 May 2007

L. Snyder and C. Shelton found a nest with 4 young, $13 \mathrm{mi}$ south of Kimball, Kimball Co. (Larry Snyder, pers. comm.). Their study also found 2 additional nests, 30 May - 4 June 2007 (Snyder and Bly 2009). Probably an extremely rare, declining regular breeder in northern Nebraska and the western edge of the Panhandle. Breeds in loosely aggregated colonies, located almost exclusively in native mixed grass prairie. One egg date reported: 4 June. One date reported for a nest with young: 30 May. One clutch size reported: 3 eggs. A two-year study was done to better understand the habitat requirements of Chestnut-collard and McCown's Longspurs in the Panhandle (Snyder and Bly 2009), but much more work is still needed.

McCown's Longspur, Rhynchophanes mccownii. Seven records. First record: M. Cary found a nest with young on 4 July 1901 on a ridge southwest of Warbonnet Canyon, Sioux Co. (Carriker 1902). H. A. Kantrud reported a nest with 4 eggs on 27 June 1977 near Agate, Sioux Co. (CNRCP). B. Wilson reported, and M. and E. Brogie photographed, a nest with 4 eggs on 9 June 1985, W of Harrison, Sioux Co. (Bray 1985). I found a nest with 3 eggs on 3 June 2000 near Harrison, Sioux Co. (Mollhoff 2001b). M. Forsberg found a nest with 3 young on 2 June 2001 near Harrison, Sioux Co. (Mollhoff 2004a). E. Brogie reported a nest with 3 eggs on 27 May 2016, S of Kimball, Kimball Co. (Ed Brogie, pers. comm.) Extremely rare and declining regular breeder in the western tier of counties in the Panhandle. Seven nests in Kimball Co. were found in shortgrass prairie with patches of bare ground between grass clumps, in crop stubble fields, and on the bare ground in fallow fields (Snyder and Bly 2009). Sometimes appears to nest in loose colonies sited on hilltops to take advantage of the wind for courtship display flights. Four egg dates: 27 May - 27 June. Seven clutch sizes reported: usually 3 - 4 eggs, mean 3.5, mode 4. Brownheaded Cowbird parasitized $14 \%$ of nests reported. 


\section{Family Passerillidae (Towhees, Sparrows, Juncos)}

Cassin's Sparrow, Peucaea cassinii. Four records. First record: On 5 June 1974 K. Sejkora found a nest with 4 eggs in a sandsage (Artemisia filifolia) grassland near Grant, Perkins Co. (Editor 1974b, UNSM, Cat.\#ZM13090). C. E. Bock and W. C. Sharf found three nests 30 June - 8 July 1993 near the dam at Lake McConaughy, Keith Co. (Bock and Scharf 1994). Rare breeder in sandsage prairie in the southwest, and in southwestern Sandhills. Four egg dates: 5 June - 8 July, no date clusters. Clutch sizes reported: 4, usually 5 eggs, sometimes 4, mean 4.8, mode 5 . May be expanding its range from northeastern Colorado. Appears to be declining range-wide. In need of further study.

Grasshopper Sparrow, Ammodramus savannarum. Three hundred thirty-four records. First record: On 13 May $1887 \mathrm{H}$. P. Saugust collected a set of 4 fresh eggs from a nest near Geneva, Fillmore Co. (WFVZ, Cat. \#70189). L. R. Sabine took 5 eggs on 5 June 1896 at Omaha, Douglas Co. (MVZ, Cat. \#7005). L. R. Sabine took 4 eggs on 6 June 1898 at Omaha, Douglas Co. (WFVZ, Cat. \#219142). L. R. Sabine took 5 eggs on 26 May 1899 near Omaha, Douglas Co. (MCZ, Cat. \#362410). M. Cary took 4 eggs on 22 May 1905 at Neligh, Antelope Co. (USNMNH, Cat. \#B30939). S. A. Rohwer reported a nest with 2 eggs, plus 2 cowbird eggs, on 10 July 1968 near Aurora, Hamilton Co. (CNRCP, \#40). Abundant regular breeder statewide, placing its ground nests in all types of native, as well as introduced grasslands. Four hundred ninety egg dates reported: 13 May - 21 August, with a peak 25 May - 25 June, then a gradual drop-off until 9 August. Clutch sizes reported: 263, usually 4 - 5 eggs, sometimes 2 - 7, rarely 8, mean 4.3, mode 4 . Multiple broods, and probably many repeat attempts following nest failure or parasitism. Brown-headed Cowbird parasitized 32\% of nests reported.

Lark Sparrow, Chondestes grammacus. Ninety-five records. First record: W. L. Carpenter collected a set of 2 eggs near Omaha, Douglas Co., on 12 June 1874 (USNMNH, Cat. \#B17353). L. Bruner took 4 eggs on 13 May 1887 at West Point, Cuming Co. (UKBI, Cat. \#95733). J. S. \& A. Pyfer took 5 eggs on 6 June 1894 at Odell, Gage Co. (CAS, Cat. \#8191). E. Van Sant took 3 eggs on 22 May 1898 at Albright, Douglas Co. (UNSM, Cat. \#ZM08837). O. A. Peterson took 5 eggs on 5 June 1901 at the Prairie Dog Creek badlands, Sioux Co. (UNSM, Cat. \#ZM08840). H. Turner noted 4 eggs on 12 July 1965 at Holstein, Adams, Co. (CNRCP, \#11). O. Bassett noted a nest with 4 eggs on 2 July 1968 on the Dismal River, near Cody Lake, Hooker Co. (CNRCP, \#151). Abundant regular breeder in grasslands and croplands statewide. Fifty-one nests were placed: on the ground $(90 \%)$ or as high as $9 \mathrm{ft}(3 \mathrm{~m})$ in shrubs and trees. One hundred one egg dates: 6 April - 24 July, bi-modal distribution, 13 May - 13 June $=60 \%$, and 15 June -14 July =34\%, makes double brooding possible. Clutch sizes reported: 88, usually 4 - 5 eggs, sometimes $3-6$, mean 4.2, mode 4. Brown-headed Cowbird parasitized $22 \%$ of nests reported.

Lark Bunting, Calamospiza melanocorys. Seventy-one records. First record: N. E. Goss collected 4 eggs on 3 June 1889 from a nest near Nebraska City, Otoe Co. (UKBI, Cat. \#95732). H. Lang took 5 eggs on 4 May 1890 at Lincoln, Lancaster Co. (CM, Cat. \#E960). J. A. Dickenson took 6 eggs on 7 June 1896 at Gresham, Seward Co. (USNMNH, Cat. \#B35596). M. A. Carriker, Jr., took 5 eggs on 18 June 1901 on Antelope Creek, Sioux Co. (UNSM, Cat. \#ZM08970). L. M. Gates took 5 eggs on 6 July 1914 at Mitchell, Scotts Bluff 
Co. (UNSM, Cat. \#ZM08975). S. Moody reported a nest with 5 eggs on 10 June 1968 near Greeley, Greeley Co. (CNRCP, \#60). Common regular breeder in the western third of the state, in areas with bare ground, either shortgrass prairie or fallow cropland. Declining, perhaps due in part to increase in irrigated farmland and resulting loss of fallow fields in that part of the state. During periods of drought early in the homestead era, the species occasionally bred east to the Missouri River in areas now covered by irrigated fields. Usually a colonial breeder with females outnumbering males 4 or $5: 1$. One hundred sixteen egg dates: 4 May - 5 August. Shows what appears to be a bi-modal distribution: 24 May - 11 June $=41 \%$, and 15 June -6 July $=53 \%$, that may indicate double broods. Clutch sizes reported: 69, usually 4 - 5 eggs, sometimes 3 - 6, mean 5.1, mode 5 . Brown-headed Cowbird parasitized $6 \%$ of nests reported.

Chipping Sparrow, Spizella passerina. Twenty-seven records. First record: W. C. Smith collected a set of 2 eggs at Long Pine, Brown Co. on 23 June 1897 (SBM, Cat. \#46). J. C. Crawford, Jr., took 4 eggs at West Point, Cuming Co. on 3 May 1900 (UNSM, Cat. \#ZM08847). J. S. Hunter took 3 eggs at Monroe Canyon, Sioux Co. on 1 June 1900 (UNSM, Cat. \#ZM08851). J. E. Stipsky noted 5 eggs at Hooper, Dodge Co. on 25 May 1930 (Stipsky 1934). J. Tate reported 2 eggs in Lincoln, Lancaster Co. on 4 June 1965 (CNRCP, \#312). Abundant state-wide breeder, wherever there are people and trees. It has a strong affinity for small ornamental conifers as nesting sites. Twenty-eight nest heights reported were $1-20 \mathrm{ft}(0.3-6 \mathrm{~m})$ up, with $79 \%$ at $4-10 \mathrm{ft}(1.2-3 \mathrm{~m})$ high. Thirty-six egg dates: 3 May - 19 August, (3 May - 14 June = 81\%). Scattered dates from 23 June -19 August might be second attempts after nest failure, or second broods. Clutch sizes reported: 27, usually 3 - 4 eggs, sometimes 2 - 5, mean 3.2, mode 4. Brown-headed Cowbird parasitized $26 \%$ of nests reported.

Clay-colored Sparrow, Spizella pallida. Seven reports, none with documentation to confirm breeding. See(Sharpe et al. 2001) for summary of reports. Nearest nest records are from Cheyenne, Laramie Co. Wyoming in 1889 (USNMNH, Cat. \#B33971, and \#B33972), and which are the only nests recorded from Wyoming (Faulkner 2010). Any territorial birds noted 20 May - 31 July should be investigated for evidence of breeding. It is not yet accepted as a breeder.

Field Sparrow, Spizella pusilla. Thirty-six records. First record: On 1 June 1985 D. Wallace collected a set of 4 eggs at Omaha, Douglas Co. (UNSM, Cat. \#ZM08868). L. Skow took 3 eggs 18 August 1895 at Omaha, Douglas Co. (WFVZ, Cat. \#220039). W. C. Smith took 3 eggs near Long Pine, Brown Co. 10 June 1897 (SBM, Cat. \#44). L. R. Sabine took 4 eggs 10 June 1897 at Omaha, Douglas Co. (MVZ, Cat. \#7042). J. T. Zimmer took 4 eggs at Child's Point, Sarpy Co., 19 May 1910 (Zimmer undated). H. L. Leavitt took a set of eggs at Omaha, Douglas Co., 6 July 1921 (MCZ, Cat. \#356929). D. C. Moody reported a nest with an egg near Greeley, Greeley Co. 9 June 1973 (CNRCP, \#1678). Abundant breeder in most of the state, except the Panhandle, where it is very rare as a breeder. Twelve nests reported: on the ground (20\%) or up to $8 \mathrm{ft}(2.4 \mathrm{~m})$ high, $92 \%$ of nests were $1.5 \mathrm{ft}$ $(0.5 \mathrm{~m})$ or lower. Thirty-six egg dates: 16 May - 18 August, bi-modal distribution: 16 May - 10 June $=53 \%$, and 16 June -17 July $=39 \%$, makes multiple broods seem likely. Clutch sizes reported: 36 , usually 3 - 4 eggs, sometimes 5 , mean 3.8, mode 4 . Brown-headed Cowbird parasitized $22 \%$ of all nests reported. 
Brewer's Sparrow, Spizella breweri. Thirty-eight records. First record: While working with M. H. Swenk in alfalfa (Medicago sativa) pollination research at the University of Nebraska Experimental Station near Mitchell, Scotts Bluff Co. on 17 June 1913, L. M. Gates found a nest with 4 eggs in a clump of alfalfa (Swenk and Gates, undated mss.). Later that year, at the same location, they took 3 eggs on 26 June (UNSM, Cat. \#ZM08853), 4 eggs 27 June (UNSM, Cat. \#ZM08854), 3 eggs 8 July (UNSM, Cat. \#ZM08855), 2 eggs 29 July (UNSM, Cat. \#ZM08857); some of which were likely 2nd attempts following disrpution of the first nest. During 3 summers there (1914-1916), they found 36 nests and salvaged the contents of nests that were destroyed by cutting hay and other aspects of their work, often only finding the nest when it was destroyed. The next nest on record held 4 young when photographed W of Harrison, Sioux Co. on 8 July 2016 by M. Brogie (Mark Brogie, pers. comm.) Rare regular breeder in the Panhandle, found most often in sandsage (Artemisia filifolia) grassland. Nests placed on ground or just above ground level in a plant. Sixty-five egg dates, bimodal distribution: 8 - 29 June $=52 \%$, and $6-28$ July $=48 \%$. Appears to be double brooded. Clutch sizes reported: 38 , usually 4 eggs, sometimes 2 - 5, mean 3.5, mode 4 .

American Tree Sparrow, Spizelloides arborea. Three reports. In a report for 1877, Aughey called the species: "Abundant in winter and a few breed here in summer." (Aughey 1878). In 1880 , he revised his note to: 'The Long [Song] Sparrow is becoming more abundant each year, but the Tree Sparrow is only present in winter." (Aughey 1880), thus negating his previous statement. J. E. Stipsky reported finding a nest with 3 eggs at Hooper, Dodge Co. on 13 May 1934 but gave no details (Stipsky 1934). It seems far more likely that the bird was either misidentified, or else an aberrant Chipping Sparrow. This report is not accepted.

Dark-eyed ("White-winged") Junco, Junco hyemalis aikeni. Ten reports, two records. First record: On 29 July 1901, M. A. Carriker, Jr., found a nest with 4 grown young in a ravine, which fledged as he looked at them, in or near Warbonnet Canyon, Sioux Co. (Carriker 1902). The nest was hidden beneath a narrow projection of a rock ledge and enclosed on the sides by earth eroding from above. I found the other reported nest on 12 June 2008 at Chadron Creek Ranch WMA, near Chadron SP, Dawes Co. It held 3 - 4 young, 3 5 days old. It was in a similar setting, but in a cavity excavated between concealing grass stems and ferns. Extremely rare regular breeder in the Pine Ridge. No egg dates have been reported. Young in the nest have been reported 12 - 29 June. The nest with four young was the only brood size reported. Anyone lucky enough, or patient enough, to track one of the wary adults to an active nest, should make an effort to record as much information as possible.

Vesper Sparrow, Pooecetes gramineus. Twenty records. First record: On 6 June 1897, D. Wallace collected a set of 3 eggs near Omaha, Douglas Co. (WFVZ, Cat. \#219014). M. Cary took 5 eggs 30 May 1901 on Warbonnnet Canyon divide, Sioux Co. (UNSM, Cat. \#ZM38832). F. H. Shoemaker noted a nest with 5 eggs 29 May 1903 at Hackberry Lake, Cherry Co. (Shoemaker undated). J. T. Zimmer took 4 eggs 8 July 1912, near Halsey, Thomas Co. (Zimmer undated). F. J. Keller reported a nest with 4 eggs 5 July 1931 near Antioch, Sheridan Co. (Swenk 1931). L. Blus reported a nest with 4 eggs on 13 June 1966 at the National Forest, Thomas Co. (CNRCP, \#66). J. Johnson documented a nest 
with eggs and young, 5 - 29 August 1984, near Concord, Dixon Co. (Jan Johnson, pers. comm.). Common regular breeder almost state-wide, but less common along our southern border. Places its nests on the ground beside or in clump of grass, beside forbs, and more recently, in early crop growth in minimum-till farm fields. Twenty-two egg dates: 15 May - 18 August, no notable date clusters. Clutch sizes reported: 22, usually 4 eggs, sometimes 3 - 5, mean 4 , mode 4 .

Baird's Sparrow, Centronyx bairdii. One record. Six reports: On 23 June 1890 N. E. Goss collected a set of 6 eggs in advanced incubation from a nest near Warbonnet Canyon, Sioux Co. (UKBI, Cat. \# 95731). This area is about 20 miles (32 km) from where birds have been seen repeatedly in migration in the last half of May (Crawford 1901, Silcock 2009a, 2010), and where Rosche reported three territorial males on 27 June 1996 (Grzybowski 1996). Territorial-acting birds were also found in that area 17 \& 26 May 2009 and 15-17, 30 May 2010 but were not present on follow-up visits. There is also a report by I. S. Trostler of a nest near Omaha, Douglas Co. which Bruner accepted (Bruner 1896, 1901), but later dismissed (Bruner et al. 1904).

Henslow's Sparrow, Centronyx henslowii. Fifteen reports. The first report states, "It may occasionally breed locally in the state, since Trostler took a set of eggs, with female bird, at Omaha, belonging to this species..." (Bruner et al. 1904), but no documentation is extant . First record: D. H. Kim reported 2 nests in 2004 at PRWCMT, Hall Co., one of which fledged 4 young (Kim 2005). S. Sullivan reported a nest with 4 eggs in 2004 near Burchard Lake, Pawnee Co. (Silcock and Jorgensen 2007). L. Negus found nests with 4, 5, \& 5 eggs, 22 - 28 June 2005 at Maskentine Lake NRD, near Stanton, Stanton Co. (Lucas Negus, pers. comm.). D. Kim reported a nest with 4 eggs $9-17$ July and 4 nests with young 19 - 30 July 2005; B. Skipper reported a nest with 1 egg on 20 May 2007 and another with 4 eggs on 7 June 2007, all at PRWCMT, Hall Co. (Dan Kim, pers. comm.). Probably extremely rare regular breeder in tallgrass prairie with post-fire or heavy grazing regime, which leaves a thatch of dead grass for nest placement. Places its nests on or near the ground. All documented nests were reported during this century. Sixteen egg dates: 20 May - 3 August, no date clusters noted. Clutch sizes reported: 7, usually 4 eggs, sometimes 5, mean 4.3, mode 4. Brown-headed Cowbird parasitized $43 \%$ of reported nests.

Savannah Sparrow, Passerculus sandwichensis. Eighteen reports. One record: Although accepted as a breeder for more than a century, the first nest was found in Sioux Co., north of Mitchell, by L. Malone and B. McKinney and held 4 eggs on 15 July 1994 (Silcock and Rosche 1994b). It is the only nest found. Probably an extremely rare regular breeder. Appears to be a colonial breeder. Most reports are from the northwest and the Sandhills. On 12 July 2011, I found a pair repeatedly carrying food to fledged, mobile young hiding in dense grass near Hay Springs, Sheridan Co. Territorial birds have been noted at that site annually since then. Current study seems to show that the species is very selective in choosing habitat, requiring a mosaic of mixed-height moist grass/sedge habitat near water, with an admixture of taller forbs for singing perches. Areas where apparently breeding birds were formerly reported which became drier, or converted to all-grass (no forbs) by haying or grazing, or infested with woody vegetation, no longer hosted breeding season birds (Mollhoff mss.). Territorial birds have been reported 22 
May - 12 June. Any birds found during the 1 June - 31 July breeding season should be investigated further for evidence of breeding.

Song Sparrow, Melospiza melodia. Twelve reports. First record: R. S. Sharpe found a nest with 3 young on 18 June 1966 in Sowbelly Canyon, Sioux Co. (Cink 1975). On 9 July 1972 C. L. Cink found a nest with 2 young at Wagon Train Lake, Lancaster Co. (Cink 1975). J. E. Ducey found a nest with 5 young on 14 May 1981 near Tecumseh, Johnson Co. (CNRCP, \#2540). S. Sullivan noted a nest with 4 young on 7 June 2005 at PRWCMT, Hall Co. (Dan Kim, pers. comm.). J. G. Jorgensen found a nest with 5 eggs 10 May 2015 near Tekemah, Burt Co. (Joel Jorgensen, pers. comm.). Abundant regular breeder, especially in riparian-edge habitat in eastern half of state. Numbers have increased markedly since Cink's 1975 report, and BBS survey data show an 8.3\% annual increase over the past decade. Nests placed at ground level or up to $3 \mathrm{ft}(1.0 \mathrm{~m})$ high. Three egg dates: 15 May - 6 June. Clutch sizes reported: 6, usually 5 eggs, mean 4.5, sometimes 3 - 4, mode 5 . More nesting information is needed.

Swamp Sparrow, Melospiza georgiana. Nine reports, four records. First record: W. W. Lemburg found a nest with 4 eggs in a marshy area near the Middle Loup River north of Cairo, Howard Co., in June 1969 (Sharpe 1970). S. J. Dinsmore noted a nest with 6 eggs near Lake McConaughy, Keith Co. on 11 June 2006 (Mollhoff 2006). D. H. Kim reported a nest with 4 eggs, plus 2 cowbird eggs, on 29 May 2007 at PRWCMT, Hall Co. (Mollhoff 2008). J. Aleman-Zometa noted a nest with 5 eggs 21 - 26 June 2008 at PRWCMT, Hall Co. (Dan Kim, pers. comm.). Rare regular breeder in central and northern Nebraska, placing its nests in wet meadows, marsh edges, and riparian areas. Four egg dates reported: 29 May - 26 June. Clutch sizes reported: 4, usually 4 - 6 eggs, mean 4.8, mode 4. Brownheaded Cowbird parasitized $25 \%$ of nests reported. More nesting information is needed. Spotted Towhee, Pipilo maculatus. Thirteen records. First record: N. E. Goss collected 4 eggs in Warbonnet Canyon, NW of Harrison, Sioux Co. on 21 June 1890 (UKBI, Cat. \#95730). On 26 June 1900 G. P. Anderson took 3 eggs at Dannebrog, Howard Co. (MVZ, Cat. \#1277). M. A. Carriker, Jr., took 4 eggs on Warbonnet Creek, Sioux Co. on 6 July 1901 (UNSM, Cat. \#ZM08915). D. Gates noted a nest with 4 eggs 2 July 1966 near Chadron, Dawes Co. (CNRCP, \#134). Common regular breeder north and west of a line from Dixon Co. in the northeast, to Red Willow Co. in the southwest. Its numbers are mixed with Eastern Towhee in a broad band along that line. Mixed-species pairs and hybrids are not uncommon along the line. Eight of ten nests reported were built on the ground, usually well hidden in woodland edge vegetation. Thirty-two egg dates: 8 May - 6 July, no date clusters noted. Clutch sizes reported: 13 , usually 4 eggs, sometimes 3 - 5, mean 3.9, mode 4 . Brown-headed Cowbird parasitized $15 \%$ of nests reported.

Eastern Towhee, Pipilo erythrophthalmus. Nineteen records. First record: W. L. Carpenter collected 3 eggs at Omaha, Douglas Co. on 4 June 1874 (USNMNH, Cat. \#B17378). L. Robbins took 4 eggs at Jamaica, Lancaster Co. 5 June 1891 (UKBI, Cat. \#95729). E. Van Sant took 3 eggs 30 May 1897 at Florence, Douglas Co. (UNSM, Cat. \#ZM08906). W. C. Smith took 2 eggs near Long Pine, Brown Co. on 20 June 1898 (SBM, Cat. \#32). L. C. Holcomb reported 4 eggs, plus 2 cowbird eggs, at Fremont, Dodge Co. on 4 June 1966 (CNRCP, \#168). Common regular breeder in southeastern third of the state. See above account on the location of the line of division and overlap, mixed-species pairs and 
hybrids with Spotted Towhee. Usually nests on ground, rarely up to $5 \mathrm{ft}(1.5 \mathrm{~m})$ up, usually at woodland edge, well hidden, often against tree root or stump. Nineteen egg dates: 8 May - 1 September ( 1 - 30 June $=78 \%$ ). Clutch sizes reported: 19 , usually 3 - 4 eggs, sometimes 2 - 5, mean 3.6, mode 4. Brown-headed Cowbird parasitized 37\% of nests reported.

\section{Family Icteriidae (Chats, Blackbirds, Meadowlarks, Orioles, Cowbirds)}

Yellow-breasted Chat, Icteria virens. Twenty-one records. First record: On 4 June 1893, I. S. Trostler collected a set of 4 eggs at Cut-off Lake (Carter Lake), Douglas Co. (WFVZ, Cat. \#225140). L. Skow took 4 eggs on 25 May 1895 at Child's Point, Sarpy Co. (WFVZ, Cat. \#225138). M. A. Carriker, Jr., took 4 eggs on 29 June 1901 on Dead Man's Creek, Sioux Co. (UNSM, Cat. \#ZM09121). F. H. Shoemaker took 4 eggs on 5 June 1898 at Albright, Douglas Co. (UNSM, Cat. \#ZM09118). J. T. Zimmer took 4 eggs on 9 June 1911 at the Nebraska National Forest, Thomas Co. (Zimmer undated). I noted a nest with 3 eggs \& 2 young on 22 June 2007 near Chadron, Dawes Co. (Mollhoff 2008). Common regular breeder in western two-thirds of the state. Breeds in both riparian and xeric upland shrub settings. Twelve nests placed $2-5 \mathrm{ft}(1.5-2.5 \mathrm{~m})$ high. Twenty-three egg dates: 26 May - 6 July (26 May - 25 June $=96 \%$ ). Clutch sizes reported: 21 , usually 4 eggs, sometimes 3 - 5, mean 3.9, mode 4. Brown-headed Cowbird parasitized 19\% of reported nests.

Yellow-headed Blackbird, Xanthocephalus xanthocephalus. One hundred fifty-eight records. First record: G. W. Sabine collected a set of fresh eggs at Cut-off (now Carter) Lake, Douglas Co., on 18 June 1893 (WFVZ, Cat. \#119947). B. E. Griffiths took 4 eggs on 1 July 1894 at Omaha, Douglas Co. (UNSM, Cat. \#ZM08726). W. Tout reported 5 eggs on 8 June 1896 near York, York Co. (Tout 1901). W. C. Smith took 2 eggs on 15 May 1897 near Long Pine, Brown Co. (SBM, Cat. \#30). R. D. Hoyt and C. A. Black collected a nest on 27 May 1914 at Crescent Lake, Garden Co. (UFMNH, Cat. \#52597). D. Teachenor took a nest on 27 May 1925 at Simeon, Cherry Co. (UKBI, Cat. \#75303). Common regular marsh breeder almost statewide, but requires deeper and more permanent water than Red-winged Blackbird. Nests are built over water in emergent cattails (Typha spp.), rushes (Juncus spp.), phragmites (Phragmites spp.), and other tall emergent vegetation. One hundred ninety-two egg dates: 4 May - 27 July (28 May - 16 June =91\%). Dates after mid-June are likely second attempts. Clutch sizes reported: 158, usually 3 - 4 eggs, sometimes 2 - 5, mean 3.6, mode 4. Brown-headed Cowbird parasitized $0.6 \%$ of nests reported.

Bobolink, Dolichonyx oryzivorus. One hundred seventy-seven records. First record: On 2 June 1906 M. Cary collected a set of 5 eggs from a nest near Neligh, Antelope Co. (USNMNH, \#B31048). A. M. Brooking collected a nest on 3 June 1915 at Inland, Clay Co. (HM, Cat. \#02312). W. Tout found a nest on 8 June 1929 near North Platte, Lincoln Co. (Tout 1947). S. L. Minneman noted a nest with 7 eggs on 9 June 1978 on Mormon Island, Hall Co. (CNRCP). M. Morton found a nest with 5 eggs on 14 June 1984 at North Platte, Lincoln Co. (Margaret Morton, pers. comm.). C. Helzer found a nest with 4 eggs on 27 June 1997 near Wood River, Hall Co. (Chris Helzer, pers. comm.). Common regular breeder, places ground nests in wet meadows and riparian marshes, occasionally also in 
red clover (Trifolium spp.), or in shrubby willows (Salix spp.) in a swampy area. Three hundred ninety-eight egg dates: 21 May - 16 July, with no clear-cut clusters. Egg dates after 20 June are likely second attempts following nest parasitism and abandonment. Clutch sizes reported: 177, usually 4 - 5 eggs, sometimes 2 - 8, mean 4.6, mode 5 . Brown-headed Cowbird parasitized $58 \%$ of all nests reported, with $35 \%$ holding as many or more cowbird eggs than host eggs.

Eastern Meadowlark, Sturnella magna. One hundred forty-three records. First record: L. Bruner collected a set of 5 fresh eggs near West Point, Cuming Co., on 20 May 1885 (UKBI, Cat. \#95744). J. S. \& A. Pyfer took 6 eggs on 13 May 1894 (CAS, Cat. \#7928), and 6 eggs on 8 June 1894 (WFVZ, Cat. \#216972), both at Odell, Gage Co. J. E. Stipsky noted 3 eggs on 15 May 1927 at Hooper, Dodge Co. (Stipsky 1934). S. L. Doole reported 5 eggs on 24 July 1968 at Lincoln, Lancaster Co. (CNRCP, \#233). Common regular breeder in tallgrass prairie grasslands in the southeast, and in tallgrass-statured wet meadows in the Sandhills and other riparian areas in central Nebraska. Nests placed on the ground and domed over for concealment, well-hidden and sometimes with a covered, tunnel-like entrance through the grass. Two hundred fifty egg dates: 29 April - 3 July (15 May - 14 June $=85 \%)$. There are indications of clusters at $17-28$ May (34\%), and again at $3-13$ June (35\%) that might indicate double broods. Any egg dates after 15 June are likely reattempts following a failed nest. Clutch sizes reported: 143, usually 4 - 5 eggs, sometimes $3-6$, mean 4.6, mode 5. Brown-headed Cowbird parasitized $34 \%$ of nests reported.

Western Meadowlark, Sturnella neglecta. Three hundred seventy-five records. First record: Dr. George Suckley collected a set of 4 eggs near Ft. Kearney, Kearney Co. on 26 June 1859 (USNMNH, Cat. \#B2174). N. S. Goss took 5 eggs on 19 June 1890 at Crawford, Dawes Co. (UKBI, Cat. \#95742). G. W. Sabine took 5 eggs on 21 May 1893 at Cutoff Lake, Douglas Co. (WFVZ, Cat. \#75740). J. Bingaman took 5 eggs on 22 May 1894 at Lincoln, Clay Co. (USNMNH, Cat. \#44479). I. S. Trostler took 4 eggs on 23 June 1895 near Cody, Cherry Co. (WFVZ, Cat. \#217370). L. Bruner took 6 eggs on 26 May 1901 above Warbonnet Canyon, Sioux Co. (UNSM, Cat. \#ZM08762). Abundant regular breeder statewide, most abundant in the vast grasslands of the Sandhills and Panhandle. Its domed ground nests sometimes have a covered, tunnel-like entryway. Six hundred forty egg dates: 28 April - 14 August (14 May - 26 June $=79 \%$ ), with no clear cut date clusters, but probably double brooded. July/August egg dates are likely attempts to replace failed clutches. Clutch sizes reported: 375 , usually 4 - 6 eggs, sometimes $3-7$, rarely 8 , mean 4.5 , mode 5 . Brown-headed Cowbird parasitized $32 \%$ of clutches reported, with $14 \%$ of all nests holding as many, or more, cowbird eggs than host eggs.

Orchard Oriole, Icterus spurius. One hundred ten records. First record: On 12 June $1887 \mathrm{~L}$. Bruner collected a set of 5 eggs near West Point, Cuming Co. (UKBI, Cat. \#95749).W. C. Smith took 3 eggs on 15 June 1893 near Long Pine, Brown Co. (SBM, Cat. \#3). J. S. \& A. Pyfer took 4 eggs on 8 June 1894 at Odell, Gage Co. (WFVZ, Cat. \#121874). A. S. Pearse took 3 eggs on 13 June 1895 at Beatrice, Gage Co. (USNMNH, Cat. \#B29742). R. H. Wolcott took 4 eggs on 14 June 1898 at Lincoln, Lancaster Co. (UNSM, Cat. \#ZM08771). M. A. Carriker, Jr., took a nest with 1 egg on 3 July 1898 at Nebraska City, Otoe Co. (MCZ, Cat. \#361111). Abundant regular breeder statewide, usually nesting in riparian 
shrub and woodland edge habitat, but also uses dry upland woods as well. Forty nests were placed 3 - $40 \mathrm{ft}(1-12 \mathrm{~m})$ high; but $70 \%$ are $4-15 \mathrm{ft}(1.5-4.5 \mathrm{~m})$ high. Forty-five egg dates: 16 May - 15 July ( 5 - 21 June $=69 \%$ ). Clutch sizes reported: 49, usually 3 - 4 eggs, sometimes $2-5$, rarely 6 , mean 3.8 , mode 4 . Smaller clutches often coincide with cowbird parasitism. Brown-headed Cowbird parasitized 39\% of nests reported.

Bullock's Oriole, Icterus bullockii. Six records. First record: W. C. Smith collected 2 eggs near Long Pine, Brown Co., on 17 July 1898 (SBM, Cat. \#29). M. A. Carriker, Jr., took 4 eggs on 16 June 1902 on Prairie Dog Creek, Sioux Co. (UNSM, Cat. \#ZM08781). I found 3 eggs on 10 June 2000 SW of Redington, Morrill Co. (Mollhoff 2001b), a nest with 1 egg at the same location on 1 July 2001 (Mollhoff 2004a), and another nest there with an egg and 3 day-old young on 22 June 2002 (Mollhoff 2004b). Uncommon breeder in the Panhandle and adjacent counties, hybridizes with Baltimore Oriole and intergrades are frequently seen. Nests placed well up in both conifers and deciduous trees, often near top of tree. Fifteen nests reported were $16-46 \mathrm{ft}(5-14 \mathrm{~m})$ high and usually near end of branch. Seven egg dates: 10 June - 17 July, no date clusters. Clutch sizes reported: 6 , usually 4 eggs, sometimes 3 , mean 3.8 , mode 4 .

Baltimore Oriole, Icterus galbula. Twenty-three records. First record: On 5 June 1894, J. S. \& A. Pyfer took a set of 4 eggs near Odell, Gage Co. (CAS, Cat. \#7979). The Pfyfers also took 4 eggs on 18 June 1894 at Odell, Gage Co. (WFVZ, Cat. \#121879). W. C. Smith took 2 eggs on 15 July 1897 near Long Pine, Brown Co. (SBM, Cat. \# 28). E. West took 5 eggs 8 June 1899 at Omaha, Douglas Co. (UNSM, Cat. \#ZM08778). A. M. Brooking took 5 eggs on 23 June 1915 at Inland, Clay Co. (HM, Cat. \#02065). B. C. Moody reported a nest with 4 eggs on 9 June 1973 near Greeley, Greeley Co. (CNRCP, \#292). D. C. Moody reported a nest with 7 eggs on 9 June 1973 near Greeley, Greeley Co. (CNRCP, \#291). Abundant regular breeder except in the Panhandle, where it is scarce, and is largely replaced by Bullock's Oriole. Twenty-eight nests were all placed in deciduous trees, usually well up. Heights reported $6-65 \mathrm{ft}(2-20 \mathrm{~m})$, with only $21 \%$ lower than $12 \mathrm{ft}(3.6 \mathrm{~m})$ high. Pensile nests usually placed at tip of drooping branch. Thirty-nine egg dates: 21 May - 15 July, no date clusters, July dates may be second attempts. Clutch sizes reported: 23 , usually 4 - 5 eggs, sometimes 2, rarely 7, mean 4.1, mode 4. Brown-headed Cowbird parasitized $4 \%$ of nests reported.

Red-winged Blackbird, Agelaius phoeniceus. Three hundred forty-one records. First record: N. S. Goss collected 4 fresh eggs at Lincoln, Lancaster Co. on 25 May 1889 (UKBI, Cat. \#95741). J. S. Hunter took 4 eggs on 28 May 1898 at Lincoln, Lancaster Co. (UNSM, Cat. \#ZM08734). W. C. Smith took 1 egg on 1 June 1898 near Long Pine, Brown Co. (SBM, Cat. \#33). M. H. Swenk took 4 eggs on 29 May 1900 near Beatrice, Gage Co. (UNSM, Cat. \#ZM08735). J. L. Childs took 5 eggs on 28 May 1908 on the Dismal River, Thomas Co. (FMNH, Cat. \#20156). I. N. Gabrielson reported an egg and young on 1 July 1913 at Crystal Lake, Dakota Co. (Gabrielson 1914). Abundant regular breeder statewide, breeding in marshes, weedy ditches, riparian or lakeside vegetation, and upland thickets. Places nests just above ground or water level to $12 \mathrm{ft}(3.5 \mathrm{~m})$ high, $86 \%$ of ninety-four nests reported were below $5 \mathrm{ft}(1.5 \mathrm{~m})$ up. Three hundred ninety egg dates: 3 May - 8 July, with two clusters at $10-31$ May (=42\%), and 2 - 23 June $(=54 \%)$, makes double broods seem likely. Scattered dates 26 June - 8 July are likely replacement 
clutches after failures. Clutch sizes reported: 341, usually 4 eggs, sometimes 3 - 5, rarely 6, mean 3.8, mode 4. Brown-headed Cowbird parasitized $18 \%$ of nests reported. In $3 \%$ of all nests, cowbird eggs equaled or outnumbered host eggs.

Brown-headed Cowbird, Molothrus ater. One thousand two hundred eighty-four records. First record: On 21 June 1890 N. S. Goss collected 1 egg from the nest of a Spotted Towhee, which also held 4 towhee eggs, in Warbonnet Canyon, Sioux Co. (UKBI, Cat. \#95748). Abundant regular resident state-wide.

Following is a list of 52 species parasitized, followed in parentheses by the number of nests reported for the species, the number of nests parasitized, and the \% parasitized. Upland Sandpiper (164-1- 0.6\%), Acadian Flycatcher (9-1-11\%), Willow Flycatcher (24-14\%), Cordilleran Flycatcher (7-1-14\%), Eastern Phoebe (80-4-5\%), Say's Phoebe (26-28\%), White-eyed Vireo (5-1-20\%), Bell's Vireo (39-5-13\%), Plumbeous Vireo (3-1-33\%), Red-eyed Vireo (13-4-31\%), Horned Lark (50-5-10\%), Tree Swallow (55-1-2\%), Blackcapped Chickadee (79-1-1\%), Sedge Wren (11-3-27\%), Mountain Bluebird (20-3-15\%), Wood Thrush (40-14-35\%), Gray Catbird (116-2-2\%), Brown Thrasher (132-8-6\%), House Finch (42-8-19\%), Pine Siskin (11-4-36\%), AmericanGoldfinch (80-13-16\%), McCown's Longspur (7-1-14\%), Spotted Towhee (13-2-15\%), Eastern Towhee (19-7-37\%), Chipping Sparrow (27-7-26\%), Field Sparrow (36-8-22\%), Lark Sparrow (88-19-22\%) Lark Bunting (69-4-6\%), Grasshopper Sparrow (263-85-32\%), Henslow's Sparrow (7-3-43\%), Swamp Sparrow (4-1-25\%), Yellow-breasted Chat (21-4-19\%), Yellow-headed Blackbird (158-10.6\%), Bobolink (177-102-58\%), Eastern Meadowlark (143-49-34\%), Western Meadowlark (375-120-32\%), Orchard Oriole (49-19-38\%), Baltimore Oriole (23-1-4\%), Red-winged Blackbird (341-61-18\%), Brewer's Blackbird (38-2-5\%), Ovenbird (7-1-14\%), Blue-winged Warbler (3-1-33\%), Kentucky Warbler (5-4-80\%), Common Yellowthroat (25-9-36\%), American Redstart (12-1-8\%), Yellow Warbler (74-19-26\%), Scarlet Tanager (7-2-29\%), Western Tanager (2-1-50\%), Northern Cardinal (71-23-32\%), Rose-breasted Grosbeak (69-5-7\%), Black-headed Grosbeak (15-1-7\%), Blue Grosbeak (26-7-27\%), Lazuli Bunting (7-1-14\%), Indigo Bunting (16-9-56\%), and Dickcissel (152-95-64\%). Six hundred four egg dates: 21 April - 29 August (6 May - 3 August 99\%). Number of eggs found in parasitized nests: 1 - 9, usually 1 - 3 eggs, sometimes 4 - 5 eggs, rarely 6 - 9 eggs. Nests with 4+ eggs often the result of more than one female cowbird parasitizing the nest.

Rusty Blackbird, Euphagus carolinus. One report. No record. There is mention of nesting in the annual nesting report for 1972 but with no supporting documentation or comment about it being out of range (Bennett 1973). In the 1972 spring migration report, the same reporter listed species as present on 13 May 1972 without further comment (Editor 1972). In the 1972 fall migration report, the same reporter listed the species as present on 11 August 1972, again without further comment (Editor 1973). Given that the closest regular breeding area is in extreme northeastern Minnesota along the Canadian border (Avery 1995) and that there is no supporting evidence, this report is not accepted.

Brewer's Blackbird, Euphagus cyanocephalus. Thirty-eight records. First record: L. J. Pickett collected a set of 4 eggs on 30 May 1894 near Wahoo, Saunders Co. (WFVZ, Cat. \#217829). Currently a rare regular breeder in the Panhandle, but there are early 
breeding records in York Co. (Tout 1902), and Knox Co. (Trostler 1896). Something of an enigma, the species is known as a grassland bird, but also breeds in badlands, pine woodland edge, and cliffs. It is a colonial breeder, with groups of 2 - 12 pairs nesting together, with all pairs of a colony adopting the same nest placement site (ground nests in grass, cavities in rocks, tucked under fallen logs, in shrubs, or in trees). Colonies that I have monitored used the same site for several years before moving elsewhere, then returning again in later years. Twenty-five nest height reports are from ground level to $13 \mathrm{ft}(4 \mathrm{~m})$ up in trees, and to $17 \mathrm{ft}(5 \mathrm{~m})$ high on a cliff. Forty-four egg dates: 9 May - 19 June, no apparent date clusters. Clutch sizes reported: 38 , usually 4 - 5 eggs, sometimes 3 - 6, mean 4.7, mode 5. Brown-headed Cowbird parasitized $5 \%$ of nests reported.

Common Grackle, Quiscalus quiscula. One hundred three records. First record: On 26 June 1859 Dr. George Suckley collected 1 egg from a nest at Ft. Kearney, Kearney Co. (USNMNH, Cat. \#B2177). N. S. Goss took 6 eggs on 11 May 1890 at Woodlawn, Lancaster Co. (UKBI, Cat. \#95747). J. A. Dickenson took 5 eggs on 7 May 1894 near Gresham, York Co. (CAS, Cat. \#8041). W. C. Smith took 1 egg on 15 May 1898 near Long Pine, Brown Co. (SBM, Cat. \#23). G. P. Anderson took 6 eggs on 14 May 1900 at Dannebrog, Howard Co. (WFVZ, Cat. \#114099). L. A. Peterson noted 5 eggs on 14 May 1960 at Grand Island, Hall Co. (CNRCP, \#803). Abundant regular breeder, often nests in colonies, breeding nearly everywhere trees are found. Colonies of 3 - 9 pairs reported. Preferentially nests in conifers, often becomes a nuisance in Christmas tree farms and tree nurseries. Sixty nests were placed $3-55 \mathrm{ft}(1-17 \mathrm{~m})$ high, often multiple nests in a single tree. One hundred seventy-three egg dates: 26 April - 5 July, (26 April - 27 May = 83\%). Clutch sizes reported: 103, usually 4 - 5 eggs, sometimes 3 - 6, mean 4.7, mode 5.

Great-tailed Grackle, Quiscalus mexicanus. Forty-six records. First record: On 17 May 1977

B. J. Rose found a nest with 3 eggs in lakeside willows at Boys Town, Douglas Co. (Editor 1977a). C. Faanes noted a nest with eggs on 13 June 1979 near Shelton, Buffalo Co. (Williams 1979). W. C. Garthright reported 4 nests with eggs or young on 30 June 1984 near Davy, Lancaster Co. (Wm. Garthright, pers. comm.). I found a colony of 17 pairs, with nests ranging from just completed to holding half-grown young, on 8 June 2001 near Ceresco, at Jack Sinn WMA, Saunders Co. Uncommon but increasing regular breeder at scattered locations almost statewide. Colonial breeder: colonies of 2 - 17 pairs reported. Like Brewer's Blackbird, colonies that I have monitored may occupy a site for several years, then relocate for several years before returning. Found nesting most commonly in marshes and lakes with tall emergent vegetation but also nests in trees, especially eastern red-cedar (Juniperus virginiana) in dry upland settings. Thirtyeight nest heights reported were: 1.5 - $3.5 \mathrm{ft}(0.5-1.0 \mathrm{~m})$ for over-water nests, and 7 $13 \mathrm{ft}(2-4 \mathrm{~m})$ when nesting in trees. Seventy-seven egg dates: 25 April - 7 July, show a bi-modal clustering of dates: 25 April - 17 May $=56 \%$, and 6 - 30 June $=32 \%$, suggest double brooding. Clutch sizes reported: 46 , usually 4 eggs, sometimes 3 - 5, mean 3.8, mode 4.

\section{Family Parulidae (Wood Warblers)}


Ovenbird, Seiurus aurocapilla. Seven records. First record: I. S. Trostler collected a set of 5 eggs, plus 2 cowbird eggs, from a hillside nest above Child's Point, Sarpy Co., on 29 May 1898 (WFVZ, Cat. \#224835). R. Mullen took 5 eggs on 14 June 1899 at Child's Point, Sarpy Co. (UNSM, Cat. \#ZM09099). F. H. Shoemaker photographed a nest with 4 eggs on 26 May 1901 at Child's Point, Sarpy Co. (Shoemaker undated, \#A0027). M. Cary took 5 eggs on 1 June 1901 in Gerlach's Canyon, Sioux Co. (UNSM, Cat. \#ZM09094), and another 4 eggs on 8 June 1901 in Warbonnet Canyon, Sioux Co. (UNSM, Cat. \#ZM09095). R. E. Dodge took an undated set of 5 eggs at Nickerson, Dodge Co. (HM, Cat. \#02248). G. Warrick reported a nest with 5 young on 1 June 2007 near Bassett, Brown Co. (Gordon Warrick, pers. comm.). I found a nest with 3 eggs on 14 June 2008 in Sowbelly Canyon, Sioux Co. Uncommon regular breeder along and near the Missouri River, the central and lower Niobrara River, and in the Pine Ridge. Ground nests are well hidden on slopes in leaf litter and vegetation, and often not found until the female is flushed from the nest when nearly stepped on. Six egg dates: 26 May - 14 June. Nests with young reported 1 - 26 June. Clutch sizes reported: 7, usually 5 eggs, sometimes 3 - 4, mean 4.7, mode 5. Brown-headed Cowbird parasitized $14 \%$ of nests reported. More study is needed. Louisiana Waterthrush, Parkesia motacilla. Five records. First record: On 10 July 1895 I. S. Trostler found a nest with 3 half-grown young in the "western part of Sarpy Co." (Trostler 1896). R. Mullen took 6 eggs on 18 May 1901 at Child's Point, Sarpy Co. (UNSM, Cat. \#ZM09100). F. H. Shoemaker photographed a nest with 3 eggs on 1 June 1902 at Child's Point, Sarpy Co. (Shoemaker undated, \# A71). Rare regular breeder in a small area in southeast Nebraska along the Missouri River north through Washington Co., and west to Jefferson Co. Ground nests placed along spring-fed streams. Five egg dates: 15 May - 1 June. Fledged young reported by 12 June. Two clutch sizes, of 3 and 6 eggs, have been reported. More study is needed and observers are encouraged to collect detailed informtion.

Northern Waterthrush, Parkesia noveboracensis. First off: terminology. The second AOU checklist (1895), listed the species: "Seiurus noveboracensis (Gmel.). Water -Thrush. Geog. Dist. Eastern United States to Illinois, and northward to Arctic America, breeding from the northern United States northward." It listed a single subspecies: "Seiurus noveboracensis notabilis (Ridgw.) Grinnell's Water-Thrush. Geog. Dist. Western United States from Indiana and Illinois westward to California, and north into British America." There are several early reports that refer to breeding:

1) In an early report, Aughey (1878) stated that he "...found the young but never saw the nest." No further documentation to support the statement has been found.

2) The species was later included in a list of birds "...that have actually been found breeding in the state...", with the citation: "Grinell's[sp.] Water Thrush. Sioux Co. (L. Bruner)." (Bruner 1901). But no documentation to support the report has been found. 3) F. H. Shoemaker photographed a nest on 26 May 1901, at Child's Point, Sarpy Co. and labelled the envelope holding the glass plate negative: "May 26, 1901. B157. Grinnells Water Thrush - nest and eggs. Child's Point, Sarpy Co., Nebraska." However, he wrote on the edge of the glass plate negative: "Louisiana Water Thrush May 26, 1901." In his field notebook the list of birds seen that day included "Louisiana Water Thrush" as entry \#36, but does not list Grinnell's Water-Thrush. In the written narrative for the day, he wrote 
"Took 3 photos of waterthrush nest with the six eggs though of course not all in sight."(Shoemaker undated).

4) On1 June 1902 Shoemaker photographed the nest of a Louisiana waterthrush with 3 eggs at Child's Point (Shoemaker undated, B153). Unfortunately, he used "water thrush" in the narrative of his field notes, but wrote "Lousiana water-thrush" on the list of species seen that day (Shoemaker undated).

Finally, his undated handwritten note appended to records of his photos, has the following:

"B152 [Grinnell's?] Water Thrush n/4 VI-15-1902 [This neg. is marked "Nest La. Water Thrush". "Later, our self-elected authorities in Nebraska proclaimed it to be Grinnell's Water Thrush; reversing their own identification... Quietly acquiescing (with our tongue in our cheek) let's say, then: Grinnell's Water Thrush]."

Note the discrepancy of the above date (June 15 1902) vs. the previous notes and photos. Unfortunately I could not locate either a photo or negative of B152, nor could I locate his field notes taken on that date.

Even though Bruner's Sioux Co. report was accepted by Ridgway (1902) and Bent (1953), Haecker et al. 1945, Rapp et al. 1958, Rapp et al. 1971) Shoemaker's reports were not mentioned there or in later checklist updates (Swenk 1915, 1920).

A more recent report is of a "... bird with a very active brood patch" that was banded on 15 June 1983, in Sarpy Co. (Green 1985).

Without adequate extant documentation available to verify any of the above, the reports cannot be accepted as proof of breeding.

Blue-winged Warbler, Vermivora cyanoptera. Three records. First record: F. H. Shoemaker photographed a nest with three eggs, plus 1 cowbird egg, on 8 June 1901 at Coffin Springs, Child's Point, Sarpy Co. (Shoemaker undated, \#A0039). Later that day, R. Mullen collected the nest and eggs (UNSM, Cat. \#ZM09067). Shoemaker photographed a nest there with 4 eggs on 18 June 1901 perhaps a replacement clutch by the same pair (Shoemaker undated, \#A0004). Extirpated as a breeder (see Sharpe et al. 2001) for a discussion of current range. Two of the reports describe ground nests, in vegetation in low, wet areas. Two egg dates: 8 - 18 June. Clutch sizes reported: 2, usually 3 - 4 eggs. Brown-headed Cowbird parasitized 33\% of nests reported.

Black-and-white Warbler, Mniotilta varia. Six reports. Three records: M. H. Swenk collected both an adult and one young warbler on the Niobrara River on 10 July 1902 near Carns, Keya Paha Co. (Swenk 1902a). J. T. Zimmer took 5 eggs on 4 June 1912 at the National Forest, Thomas Co. (Zimmer 1913). N. L. Ford collected several males (UKBI, Cat. \#34106, 34107, 34110), and a juvenile (UKBI, Cat. \#34109), on 5 - 9 July 1957 at the National Forest, Thomas Co. (Ford 1959). Rare regular breeder along the central Niobrara River and in the Pine Ridge. It nests in cool damp canyons, placing its nests on the ground. One egg date: 4 June. Nest-building has been reported by 21 May. One clutch size reported: 5 eggs. More study is needed.

Prothonotary Warbler, Protonotaria citrea. Twelve reports, three records. First record: F. H. Shoemaker collected 3 fresh eggs from a nest at Child's Point, Sarpy Co., on 17 June 1900 (UNSM, Cat. \#ZM09066). R. Mullen took 4 eggs on 29 May 1901 near Bellevue, Sarpy Co. (UNSM, Cat. \#ZM09064). D. Walters submitted a detailed report of nest- 
building on 21 June 1959 along Beaver Creek, Boone Co. (Gates 1959). M. Wright found a nest with 5 eggs on 27 June 2000 in a bluebird box near Brownville, Nemaha Co.

(Silcock 2000b). Extremely rare, probably regular breeder along the lower Platte River, and lower Missouri River. It places its nests in cavities or nest boxes near or over water. Three egg dates: 29 May - 27 June. Nest-building has been reported 8 May - 21 June. Three clutch sizes reported: 3, 4, and 5 eggs. More detailed study is needed.

Tennessee Warbler, Oreothlypis peregrina. Two reports. A singing male with enlarged testes was collected near Rushville, Sheridan Co., on 30 May 1965 but no other breeding activity was noted, nor was there any suggestion that it, or others seen in the area, might be breeding (Short 1966). A singing male was reported, along with a female with "a very active brood patch" which was netted and banded at North Platte, Lincoln Co., on 18 May 1986 (Editor 1986, Bennett 1987). No actual breeding activity was documented or reported, and the date is within the migration season (Sharpe et al. 2001). The nearest known breeding record is hundreds of miles away in northeast South Dakota (Tallman et al. 2002), and the nearest regular breeding is even farther away in northeastern Minnesota (Martell and Pfannmuller 2018). In the absence of further documentation, neither report is accepted.

Nashville Warbler, Oreothlypis ruficapilla. Three reports.

1) S. Aughey reported "On June 10,1865, I found a young one that had just left the nest and flew with difficulty. As it was alone, I killed it to find the contents of its stomach." (Aughey 1878). Unfortunately the specimen cannot be found.

2) M. A. Carriker, Jr., collected a female on 11 June 1900, "... with eggs in her ovary which were 2 - $3 \mathrm{~mm}$ in diameter." "The peculiar manner in which a bird flushes when coming from a nest was evident in her actions; but although I searched closely I was unable to locate one." (Carriker 1901). The statement of "...eggs in her ovary..." is a misnomer, as an egg is not formed until well down the oviduct. Developing ova 2 - $3 \mathrm{~mm}$ in size remain in the ovary and do not become eggs for some time, perhaps for a day or more.

3) In 1961, H. J. Turner reported the species as 'nesting' near Bladen, Webster Co. (Wensien 1962).

While some of the above may suggest breeding, given that the nearest usual breeding, both then and now, is in northern Minnesota (Martell and Pfannmuller 2018), without well-documented proof of breeding, these reports are not accepted.

Virginia's Warbler, Oreothlypis virginiae. No records. Listed here due to disjunct breeding populations in South Dakota west of the Black Hills (Tallman et al. 2002) and southeastern Wyoming (Faulkner 2010). It breeds in dense thickets of mountain mahogany (Cercocarpus montanus) which is found in the Panhandle, with extensive stands especially in Morrill and Banner counties. Nest placed at or near ground level. Birds found there 20 May - 5 July should be closely investigated. Not yet accepted as a breeder.

MacGillivray's Warbler, Geothlypis tolmiei. Three reports. "...at intervals during the summer of 1901 birds were seen in thickets of Rhus trilobata [now, Rhus aromatica, skunkbush sumac] in bad lands pockets. I have no doubt that they were breeding in the latter locality." (Cary 1902). On 25 July 1999, two were observed at Gilbert-Baker WMA, Sioux 
Co., one of which was a suspected young bird (Silcock 1999a). On 14 June 2003, a singing bird was located in Sioux Co., also at Gilbert-Baker WMA (Silcock 2003a). The species breeds in the mountains of Wyoming (Faulkner 2010) and in the Black Hills, South Dakota (Tallman et al. 2002). They breed in shrubby habitat in both xeric and riparian settings, placing nest near ground level. Any breeding season sightings (15 May - 15 July) should be investigated. Not yet accepted as a breeder.

Mourning Warbler, Geothlypis philadelphia. One report. No records. Aughey published a vague report without any date, stating that "... in the southeastern part of the state ...once saw old birds feed the young that had left the nest..." and admitted he had never found the nest (Aughey 1878). It was accepted without question on later checklists (Bruner et al. 1904) and (Haecker et al. 1945). Such a vague report provides no basis to claim breeding by a species so far from its known range. It is not accepted.

Kentucky Warbler, Geothlypis formosa. Four records. First record: R. Mullen collected a nest with 4 eggs, plus 2 cowbird eggs, on 1 June 1901 at Child's Point, Sarpy Co. (UNSM, Cat. \# ZM09103). F. H. Shoemaker photographed a nest with 4 cowbird eggs (but no warbler eggs) on13 June 1901 at Child's Point, Sarpy Co. (Shoemaker undated, \#B128). G. Hudson collected a nest with 4 eggs, plus 2 cowbird eggs on 30 May 1936 at Rock Bluff, Cass Co. (CRCM, Cat. \#76-41, Hudson 1937). J. Brenneman reported a nest with 4 eggs on 15 June 2000 at Neale Woods, Washington Co. (Mollhoff 2001b). Rare regular breeder in counties along and near the Missouri River from Washington Co. south. Places its nests on or slightly above the ground, in leaf litter or beside the base of a tree, in forest with an open understory. Four egg dates: 30 May - 15 June. Clutch sizes reported: 4 , usually 4 eggs, mean 4.0, mode 4. Brown-headed Cowbird parasitized 75\% of nests reported.

Common Yellowthroat, Geothlypis trichas. Twenty-five records. First record: On 9 June $1893 \mathrm{~L}$. Skow collected a set of 3 eggs from a nest near Omaha, Douglas Co. (WFVZ, Cat. \#225005). W. C. Smith took 3 eggs on 10 August 1897 near Long Pine, Brown Co. (SBM, Cat. \#13). R. Mullen took 3 eggs on 8 June 1901 near Coffin Springs, Sarpy Co. (UNSM, Cat. \#ZM09105). J. T. Zimmer took 4 eggs, plus 2 cowbird eggs on 9 June 1910 at Lincoln, Lancaster Co. (Zimmer undated). L. C. Holcomb noted a nest with 4 eggs, plus 1 cowbird egg, on 10 June 1966 at Fremont, Dodge Co. (CNRCP, \#122). Abundant regular breeder statewide, most often found near water in marshes, riparian areas, and lakes, but also occasionally found nesting in thickets far from any water. Nests placed on or just above ground level, usually well hidden in vegetation. Fifteen egg dates: 31 May 10 August, no date clusters noted, but spread of dates suggests double broods. Clutch sizes reported: 25 , usually 4 - 5 eggs, sometimes 3 , mean 4.0, mode 4 . Brown-headed Cowbird parasitized $36 \%$ of nests reported.

American Redstart, Setophaga ruticilla. Twelve records. First record: On 18 June 1893 G. W. Sabine and I. S. Trostler collected a set of 4 eggs east of Cutoff Lake, Douglas Co. (WFVZ, Cat. \#225450). D. R. Wallace took 3 eggs on 29 May 1897 near Bellevue, Sarpy Co. (WFVZ, Cat. \#225452). M. A. Carriker, Jr., took 4 eggs on 31 May 1898 in Otoe Co. (UNSM, Cat. \#ZM09125). R. Mullen took 4 eggs on 20 June 1899 at Childs Timber, Sarpy Co. (UNSM, Cat. \#ZM09130). J. J. Dinan noted a nest with 1 egg on 25 June 1999 on West Ash Creek, Dawes Co. (Mollhoff 2001b). Uncommon regular breeder mainly on the 
Missouri River, the Niobrara River west into Cherry County, in riparian canyon bottoms in the Pine Ridge, and scattered locations on rivers elsewhere. Thirteen nests placed in trees and shrubs $4-25 \mathrm{ft}(1.2-7.5 \mathrm{~m})$ high; $4-12 \mathrm{ft}(1.2-3.6 \mathrm{~m})=92 \%$. Nine egg dates: 29 May - 29 June, no date clusters noted. Clutch sizes reported: 12, usually 4 eggs, sometimes 3, mean 2.7, mode 4. Brown-headed Cowbird parasitized $8 \%$ of nests reported.

Cerulean Warbler, Setophaga cerulea. Three or four records. First record: F. H. Shoemaker photographed a nearly feathered chick, standing on the rim of its nest, on 24 June 1900 at Child's Point, Sarpy Co. (Shoemaker undated, \#A0098). J. E. Wallace reported that he found three nests near Bellevue, Sarpy Co. in 1900, with 3 eggs, 4 eggs, and one with a single young. The nest with a single chick might have been the above nest photographed by Shoemaker, since Shoemaker's notes mention that they sometimes worked together (Shoemaker undated, Wallace 1901). Sporadic, or extremely rare, but might be a regular breeder. Most reports are directly on the Missouri River, or in the counties that border it. Nests well up in trees, with reported nests $40+\mathrm{ft}(12+\mathrm{m})$ high. No egg dates reported. Nest-building by 17 May, another bird apparently incubating noted on 14 May. Two clutch sizes, of three and four eggs, have been reported. Any breeding season birds (15 May - 20 July) should be investigated and reported.

Northern Parula, Setophaga americana. Several reports. One well documented nest record.

1) S. Aughey reportedthat "It reaches Nebraska about the 1st of May, and is found principally along timber belts and in orchards. I have frequently seen the young soon after leaving the nest, but the nest itself I have never found." (Aughey 1878). This statement was cited by Cooke (1888), Bruner (1901), and Bruner et al. 1904), but no documentation has surfaced. It is not accepted.

2) R. Benedict and R. Green reported an adult feeding fledged young in 1986 in Sarpy Co.

3) B. Padelford reported an adult feeding one young on 5 September 1991 along Gifford Road, Sarpy Co. (Barbara Padelford, pers. comm.).

4) C. Klaphake reported a pair of adults with a juvenile on 28 June 2003 at Fontenelle Forest, Sarpy Co. (Silcock 2003b).

5) On 13 June 2006 W. F. Huser and J. Probst found one of a pair incubating a nest at Ashford Scout Camp, near Winnebago, Thurston Co. (Silcock 2006).

6) C. Klaphake found a bird gathering nest material on 21 May 2012 in SE Washington Co. (Silcock 2012a).

7) E. C. Hopps found both adults feeding young in a nest on 27/28 May 2012 near Brownville, Nemaha Co. On 29 May with the young apparently fledged, the adults were noted foraging and calling in the area (Eric Hopps, pers. comm.).

The few reports are from mature deciduous forest, but reports are too few and sporadic to characterize further. Any reports of this edge-of-range, declining species merit further investigation.

Yellow Warbler, Setophaga petechia. Seventy-four records. First record: W. L. Carpenter collected an egg from a nest at Omaha, Douglas Co., on 12 June 1874 (USNMNH, Cat. \#B17379). N. E. Goss took 5 eggs on 11 June 1890 at Lincoln, Lancaster Co. (UKBI, Cat. \#95724). I. S. Trostler took 5 eggs on 4 June 1893 at Cut Off Lake, Douglas Co. (WFVZ, 
Cat. \#224137). B. E. Griffiths took 5 eggs on 27 May 1894 near Florence, Douglas Co. (UNSM, Cat. \#ZM09087). L. R. Sabine took 5 eggs on 5 June 1895 at 53rd \& Center St., Omaha, Douglas Co. (Shoemaker undated). L. R. Sabine took 4 eggs on 30 May 1898 at Child's Point, Sarpy Co. (MVZ, Cat. \#1911). Abundant regular breeder statewide, nests most often in riparian shrub habitat. Thirty-six nests were placed $1.5-48 \mathrm{ft}(0.5-14.5$ $\mathrm{m})$ high, usually $2-10 \mathrm{ft}(0.6-3 \mathrm{~m})$ high $=81 \%$, rarely $12-48 \mathrm{ft}(3.6-14.5 \mathrm{~m})$ high = $17 \%$. Sixty-nine egg dates reported: 16 May - 17 July (30 May - 16 June $=73 \%$ ). No notable date clusters to indicate more than one brood. Dates after mid-June are likely second attempts following nest failures. Clutch sizes reported: 74, usually 4 - 5 eggs, rarely 3, mean 4.3, mode 4. Brown-headed Cowbird parasitized $26 \%$ of nests reported. Parasitism sometimes defeated by adding nest material atop cowbird eggs and burying the cowbird eggs.

Chestnut-sided Warbler, Setophaga pensylvaniica. Three reports. Two records: I. S. Trostler submitted a report (Trostler 1896) to Bruner for his 1896 publication (Bruner 1896), stating "I took a set of 4 eggs \& nest June 23 - 94." There is a Brown-headed Cowbird egg, collected on 23 June 1894, by Trostler, in Douglas Co. (WFVZ, \#75529). The 'Remarks' section with this cowbird egg states: "Set contains an unknown number of eggs of Chestnut-sided Warbler (Dendroica pensylvanica). Additional data on card." Upon enquiry, WFVZ supplied a PDF of the original nest card that accompanied the cowbird egg. On it Trostler noted that the nest was "in a dogwood thicket $3 \mathrm{ft}$ from ground, composed of grapevine bark strips willow down and lined with hair \& cattail cotton. The egg was in the above described nest which belonged to a Chestnut-sided Warbler."

The other record was made by M. Witschy and A. Kenitz on12 July 1975 when they saw an adult feeding young near Scott's Bluff National Monument, Scotts Bluff Co. (Bennett 1976, Alice Kenitz, pers. comm.).

Sporadic breeder.

Yellow-rumped (Audubon's) Warbler, Setophaga coronata auduboni. Two records. First record: M. Cary collected a set of 4 eggs from a nest near Warbonnet Canyon on 27 June 1901 (UNSM, \#ZM09092). The only other nest reported held 4 young in West Ash Creek canyon, Dawes Co., on 12 June 1999 (Mollhoff 2001b). Rare regular breeder in the pine forests of the Pine Ridge and probably of the Wildcat Hills. Places its nests near the top of pine trees. One egg date: 27 June. One clutch size reported: 4 eggs. The species is very adept at hiding its nests, and even better at decoying observers away from them. Much work remains to be done.

Yellow-throated Warbler, Setophaga dominica. Three reports. No detailed nest records. First report: J. Toll found a bird gathering nest material in Sarpy Co. on 4 May 1989 (Grzybowski 1989a). On 6 - 9 September 1999, B. and L. Padelford observed a pair of adults feeding two young at Fontenelle Forest, Bellevue, Sarpy Co. (Silcock 1999b). On 1 May 2004, B. and L. Padelford reported two birds carrying nest material at Fontenelle Forest, Bellevue, Sarpy Co. (Silcock 2004). Possibly a regular breeder along the Missouri River, usually places its nests high in sycamore trees.

Prairie Warbler, Setophaga discolor. One report. Aughey states "I have seen the young in Dakota County and found one nest in Richardson County, near the Nemaha [River], in a 
papaw bush, four and a half feet from the ground. It was in a fork." (Aughey 1878). Goss (1891) states its range as "Eastern United States, ... west into Nebraska and Kansas; breeds in suitable localities throughout its United States range." Taylor (1888) refers to it as: "Summer resident; common." Bruner cites all of the above (1896). Later he comments that "....but most recent observers do not find it so [common] by any means."(Bruner et al. 1904) He also lists dates of observations of 1, 2, 4, and 14 June; all of which are in line with listed egg dates (Bent 1953). This observation was also accepted as a breeding record later (Dunn and Garrett 1997). In discussing the known history of the species, the authors commented on its early range-wide scarcity, followed by an increase with the clearing of the eastern forests by European settlers, with a resultant increase in shrubby edge habitat (Nolan et al. 1999). This may be continuing locally along power line corridors in which such habitat is maintained permanently. Thus, the early reports of abundance, followed by a drop in numbers are consistent with later findings. Interestingly, it was not detected during the Kansas Breeding Bird Atlas Project (Busby and Zimmermann 2001). Thus Aughey's early, incomplete report seems to coincide with the known facts. The nearest current breeding is probably in Missouri (Jacobs and Wilson 1997, Robbins 2018). Currently, it must be considered extirpated as a breeder.

\section{Family Cardinalidae (Tanagers, Cardinal, Grosbeaks, Buntings, Dickcissel)}

Summer Tanager, Piranga rubra. Eight reports, four records. First record: N. E. Goss collected a set of 3 eggs near Lincoln, Lancaster Co., on 3 July 1890 (UKBI, Cat. \#95726). Padelfords reported a nest with 2 young on 2 August 1980 at Schramm Park SRA, Sarpy Co. (B. \& L. Padelford 1980). I found a nest with 1 egg and 2 small young on 28 June 2002 at ICSP, Richardson Co. (Mollhoff 2004b). E. C. Hopps reported on a pair 11 June - 10 September 2010 and presents compelling evidence of double-brooding by the species (Hopps 2011). Rare regular breeder, nearly restricted to mature deciduous forests along the Missouri River and adjacent streams. Three nest heights reported are 15 - $30 \mathrm{ft} \mathrm{(4.5-9}$ m) high. Six egg dates: 28 June - 25 August, with no date clusters. Clutch sizes reported: 2 , both are of 3 eggs, mean 3 , mode 3 .

Scarlet Tanager, Piranga olivacea. Seven records. First record: On 28 June 1889 N. E. Goss collected a set of 3 eggs at Woodlawn, Lancaster Co. (UKBI, Cat. \#95727). E. West took 3 eggs on 30 May 1897 at Omaha, Douglas Co. (UNSM, Cat. \#ZM08978). M. A. Carriker, Jr., took 3 eggs on 17 June 1898 in Otoe Co. (UNSM, Cat. \#ZM08977). F. H. Shoemaker photographed a nest on 26 May 1901, at Child's Point, Sarpy Co. (Shoemaker undated, \#B179). Mrs. W. Tout found a nest with 4 eggs, plus a cowbird egg, on 12 June 1938 at North Platte, Lincoln Co. (Tout 1947). Rare regular breeder in mature deciduous forest along the Missouri River, the Niobrara River west to Keya Paha Co., the lower Platte and Elkhorn Rivers and Salt Creek to Saunders and Seward counties. Nests are placed in deciduous trees 10 - $30 \mathrm{ft}$ ( 3 - $9 \mathrm{~m}$ ) high. Seven egg dates: 16 May - 21 June, with no date clusters. Clutch sizes reported: 7, usually 3 - 4 eggs, mean 3.3, mode 3. Brown-headed Cowbird parasitized $29 \%$ of nests reported.

Western Tanager, Piranga ludoviciana. Two records. First record: On 27 July 1901 M. A. Carriker, Jr., found a nest with 3 eggs near the tip of a branch on a ponderosa pine 
(Pinus ponderosa) NW of Harrison, Sioux Co. (Carriker 1902). J. J. Dinan found a nest with 3 eggs, plus 4 cowbird eggs, on 12 June 1999 on West Ash Creek, Dawes Co. (Mollhoff 2001b). Rare regular breeder in the pine forests of the Pine Ridge and probably the Wildcat Hills. The nests are well-hidden among the boughs and rarely found. Two egg dates: 12 June - 27 July. Clutch sizes reported: 2, one nest with 3 eggs, the other with 3 host eggs, plus 4 cowbird eggs. Brown-headed Cowbird parasitized $50 \%$ of reported nests.

Northern Cardinal, Cardinalis cardinalis. Seventy-one records. First record: L. Robbins collected a set of 3 eggs at Jamaica, Lancaster Co., on 17 June 1892 (UKBI, Cat. \#95734). M. H. Swenk took 2 eggs, plus a cowbird egg, on 14 June 1899 near Beatrice, Gage Co. (UNSM, Cat. \#ZM08925). R. Mullen took 3 eggs on 31 May 1901 at Child's Point, Sarpy Co. (UNSM, Cat. \#08926). M. B. Shook reported a nest with 3 eggs on 29 April 1932 at Omaha, Douglas Co. (Swenk 1932). Mrs. W. H. Nielsen reported a nest with 3 eggs, on 19 April 1965 at North Platte, Lincoln Co. (CNRCP, \#114). L. Blus reported a nest with 3 eggs on 28 May 1965 near Thedford, Thomas Co. (CNRCP, \#120). Abundant regular breeder, especially in the east. It expanded west with European settlement and with the growth of riparian woodlands along the rivers. Westward movement is up the Platte River nearly to the western border, but still rare in the Sandhills and the rest of the Panhandle. Forty-four egg dates: 10 April - 5 September (10 April - 15 July =95\%). Up to three broods reported. Clutch sizes reported: 34 , usually 3 - 4 eggs, sometimes 2, rarely 5, mean 3.1, mode 3. Brown-headed Cowbird parasitized 32\% of nests reported.

Rose-breasted Grosbeak, Pheucticus ludovicianus. Sixty-nine records. First record: N. E. Goss collected a set of 4 eggs near Lincoln, Lancaster Co., on 25 May 1889 (UKBI, Cat. \#95736). F. H. Andrus took 4 eggs on 24 May 1891 at Omaha, Douglas Co. (WFVZ, Cat. \#90125). E. Van Sant took 4 eggs on 29 May 1898 at Albright, Douglas Co. (UNSM, Cat. \#ZM08944). W. C. Smith took 1 egg on 6 June 1898 near Long Pine, Brown Co. (SBM, Cat. \#20). J. S. Hunter took 4 eggs on 15 June 1899 at Saltillo, Lancaster Co. (UNSM, Cat. \#ZM08934). J. E. Stipsky noted 3 eggs on 31 May 1931 at Hooper, Dodge Co. (Swenk 1936). K. Fiala reported a nest with 3 eggs on 21 June 1966 at Beatrice, Gage Co. (CNRCP, \#55). Common regular breeder in shrubby, riparian woodland edge habitat in the eastern third of the state, decreasing westwardly, where it overlaps with, and hybridizes with the Black-headed Grosbeak. Mixed-species pairs are found occasionally in the overlap zone, along with their hybrid offspring. Nineteen nest heights reported: 4 - $20 \mathrm{ft}(1.2-6 \mathrm{~m}), 8-14 \mathrm{ft}(2.4-4.2 \mathrm{~m})=74 \%$. Forty-one egg dates: 13 May - 9 July (13 May - 14 June $=99 \%)$. No noticeable date clusters noted. Clutch sizes reported: 69 , usually 3 - 4 eggs, sometimes 2 , rarely 5 , mean 3.3, mode 3. Brownheaded Cowbird parasitized $7 \%$ of nests reported.

Black-headed Grosbeak, Pheucticus melanocephalus. Fifteen records. First record: On 25 May 1889 N. E. Goss collected a set of 4 eggs from a nest near Lincoln, Lancaster Co. (UKBI, Cat. \#95735). G. P. Anderson noted a nest with 4 eggs in 1900 near Dannebrog, Howard Co. (Anderson 1901). F. H. Shoemaker noted a nest with 4 eggs on 2 June 1903 at Valentine, Cherry Co. (Shoemaker undated). A. M. Brooking took 3 eggs on 30 May 1914 at Inland, Clay Co. (HM, Cat. \#22723). C. A. Black took 4 eggs on 20 May 1926 at Kearney, Buffalo Co. (HM, Cat. \#21933). On 19 May 1930 Mrs. A. E. Sheldon noted the 
presence of two males at her feeder at South 13th \& 23rd St, Lincoln, Lancaster Co., and reported them feeding young later (Swenk 1930). In a followup, Swenk elaborated that she had banded 11 adults and 3 small young in 1930 and that when they returned in May 1931, among them was a hybrid Black-headed X Rose-breasted male, which Swenk described in detail (Swenk 1931, 1936). Uncommon regular breeder in shrubby, woodland edge habitat in western half of the state. See comments above concerning overlap and hybridization with Rose-breasted Grosbeak. Thirteen nest heights reported: 3 - $30 \mathrm{ft}(1.0-9 \mathrm{~m})$ high, 5 - $18 \mathrm{ft}(1.5-5.5 \mathrm{~m})=77 \%$. Eleven egg dates: 17 May - 9 July, with no date clusters noted. Clutch sizes reported: 15 , usually 4 eggs, sometimes 3 , rarely $5-6$, mean 4.0 , mode 4 . Brown-headed Cowbird parasitized $7 \%$ of reported nests.

Blue Grosbeak, Passerina caerulea. Twenty-six records. First record: W. C. Smith collected a nest with two eggs on 13 June 1899 near Long Pine, Brown Co. (SBM, Cat. \#39). J. T. Zimmer took 3 eggs, plus a cowbird egg, on 18 July 1908 at Lincoln, Lancaster Co. (Zimmer undated). J. T. Zimmer noted a nest with 3 eggs on 6 July 1911 at Haigler, Dundy Co. (Swenk and Zimmer 1912). O. Bassett documented a double clutch at the ranch near Sand Beach Lake, NW of Tryon, McPherson Co., from the first nest-building on 1 June 1955, through fledging of the second clutch on 4 August 1955 (Bassett 1956). D. Gates reported a nest with 4 eggs on 8 July 1967 at Chadron, Dawes Co. (CNRCP, \#35). D. C. Moody reported a nest with 2 eggs on 12 August 1971 near Greeley, Greeley, Co. (CNRCP, \#74). Abundant regular breeder statewide in grasslands, placing its nests in forbs, shrubs, or small trees. Eleven nest heights reported: 1 - $12 \mathrm{ft}(0.3-3.6 \mathrm{~m})$ high, 1 - $5 \mathrm{ft}(0.3-1.5 \mathrm{~m})=82 \%$. Fifty-two egg dates: 5 June -1 August; two date clusters: 5 - 25 June $=58 \%, 6-25$ July $=42 \%$, suggest double broods. Clutch sizes reported: 26 , usually 2 - 4 eggs, rarely 1 - 5, mean 3.4, mode 4. Brown-headed Cowbird parasitized $27 \%$ of reported nests.

Lazuli Bunting, Passerina amoena. Five records. First record: M. A. Carriker, Jr., collected 4 fresh eggs on 1 July 1901 near the mouth of Warbonnet Creek canyon, Sioux Co. (UNSM, Cat. \#ZM08950). Carriker collected 5 eggs on 10 July 1901 at the mouth of Jim Creek canyon, Sioux Co. (UNSM, Cat. \#ZM08951). A. M. Brooking took 2 eggs on 23 June 1915 at Spring Ranch, Clay Co. (HM, Cat. \#02268). E. M. Brogie noted a nest with 3 eggs on 10 July 1977 at Hoskins, Wayne Co. (Ed Brogie, pers. comm.). Rare regular breeder in shrubs at the grassland - woodland edge in the Panhandle, and occasionally found further east where it overlaps with Indigo Bunting. In that area hybrids may outnumber 'pure' birds of either species (Sharpe et al. 2001). Five nest heights reported: 2 - $5 \mathrm{ft}(0.6$ - $1.5 \mathrm{~m}$ ) high. Five egg dates reported: 23 June -10 July ( 1 - 10 July $=80 \%)$. Clutch sizes reported: 7, usually 3 - 4 eggs, sometimes 2 , mean 3.5, mode 3. Brown-headed Cowbird parasitized $14 \%$ of nests reported.

Indigo Bunting, Passerina cyanea. Sixteen records. First record: L. Skow collected a nest with 4 fresh eggs at Omaha, Douglas Co., on 4 July 1894 (WFVZ, Cat. \#222049). B. E. Griffiths took 2 eggs on 23 June 1895 at Omaha, Douglas Co. (UNSM, Cat. \#ZM08949). J. S. Hunter took 2 eggs on 28 June 1899 at Saltillo, Lancaster Co. (UNSM, Cat. \#ZM08947). J. T. Zimmer took 5 eggs, plus 2 cowbird eggs, on 25 July 1907 at Lincoln, Lancaster Co. Zimmer also took 5 eggs, plus 2 cowbird eggs, on 27 July 1907 at Lincoln, Lancaster Co. (Zimmer undated). I. N. Gabrielson noted 3 eggs on 26 July 1913 at Crystal Lake, Dakota 
Co. (Gabrielson 1914). L. C. Holcomb reported a nest with 2 eggs, plus 3 cowbird eggs on 20 June 1966 at Fremont, Dodge Co. (CNRCP, \#82). Interestingly, Tout, commented that in his 40 years there, despite searching, he had never found a nest in Lincoln Co. (Tout 1947). Common regular breeder in eastern half of state, with fewer found as the Panhandle is approached, where it overlaps with the range of Lazuli Bunting. See remarks above about hybridization with that species. Nests placed in shrubs at woodland edge habitats, especially in riparian areas. Seven egg dates: 10 June - 27 July, no date clusters noted. Clutch sizes reported: 16 , usually $4-5$ eggs, sometimes 3 , mean 3.2, mode 5. Brown-headed Cowbird parasitized $56 \%$ on nests reported.

Dickcissel, Spiza americana. One hundred fifty-two records. First record: On 13 June 1874 W. L. Carpenter collected a set of 5 eggs at Omaha, Douglas Co. (USNMNH, Cat. \#B17338). N. E. Goss took 3 eggs on 14 June 1890 at Lincoln, Lancaster Co. (UKBI, Cat. \#95738). B. E. Griffiths took 4 eggs on 15 July 1894 near Florence Lake, Douglas Co. (UNSM, Cat. \#ZM08969). E. R. West took 6 eggs on 11 June 1898 near Omaha, Douglas Co. (WFVZ, Cat. \#69853). D. Chase took 5 eggs on 22 May 1899 in Sarpy Co. (OMNH, Cat. \#1311). L. R. Sabine took 3 eggs on 31 May 1899 at Ambler Place, Douglas Co. (USNMNH, Cat. \#B45002). M. A. Carriker, Jr., took 4 eggs on 26 June 1901 on Jim Creek, Sioux Co. (UNSM, Cat. \#ZM08957). L. Bruner noted 2 eggs and a broken shell nearby on 28 June 1901 at the Bruner Brothers Ranches near Swan Lake, Holt Co. (Bruner undated). J. Lueshen reported a nest with 3 eggs on 9 August 1965 near Wisner, Cuming Co. (CNRCP, \#16). Abundant regular breeder, at times state-wide, but some years much reduced or nearly absent in the Panhandle and western Sandhills. Nests placed in mixed-grass and tallgrass prairie, often showing an affinity for alfalfa hayfields. Nests placed on the ground (74\%), slightly above ground in vegetation (25\%), or rarely up to $7 \mathrm{ft}(2 \mathrm{~m})$ high in shrubs. Four hundred twenty-four egg dates: 19 May - 18 August, in two clusters, (1 June -8 July $=70 \%$ ), (11 July - 9 August $=26 \%$ ), could indicate a combination of multiple or replacement clutches. Clutch sizes reported: 152, usually 3 5 eggs, rarely $6-9$, mean 3.6, mode 4. Brown-headed Cowbird parasitized $64 \%$ of nests reported, with the number of cowbird eggs equal to, or greater than, host eggs in $50 \%$ of nests, and $4 \%$ of nests holding only cowbird eggs. 


\section{References cited}

American Ornithologists' Union. 1886. The Code of Nomenclature and Check-list of North American Birds. American Ornithologists' Union, New York, New York. 392 pp.

American Ornithologists' Union. 1895. Checklist of North American Birds, second and revised edition. American Ornithologists' Union, New York, New York. 372 pp.

American Ornithologists' Union. 1998. Check-list of North American Birds, seventh edition. American Ornithologists' Union, Washington, District of Columbia. 829 pp.

Anderson, G. P. 1900. The Belted Piping Plover (Aegialitis meloda circumcincta). Oologist 17: 156.

Anderson, G. P. 1901. Black-headed Grosbeak (Habia melanocephala). Proceedings of the Nebraska Ornithologists' Union 2: 98.

Aughey, S. 1878. Notes on the Nature of the Food of the Birds of Nebraska, Appendix 2: 13-62. In: The First Report of the U. S. Entomological Commission for the year 1877, relating to the Rocky Mountain Locust. Government Printing Office, Washington, District of Columbia. 477 pp, plus Appendix 1-27, 295 pp.

Aughey, S. 1880. Sketches of the Physical Geography and Geology of Nebraska. Daily Republican Book and Job Office, Omaha, Nebraska. $326 \mathrm{pp}$.

Avery, M. L. 1995. Rusty Blackbird (Euphagus carolinus). In The Birds of North America, No. 200 (A. Poole and F. Gill, eds.). The Academy of Natural Sciences, Philadelphia, Pennsylvania and The American Ornithologists' Union, Washington, District of Columbia.

Baicich, P. J. and C. J. O. Harrison. 1997. A Guide to the Nests, Eggs, and Nestlings of North American Birds. Academic Press, San Diego, California. 347 pp.

Bassett, O. 1956. A summer with Blue Grosbeaks. Nebraska Bird Review 24: 5-6.

Bates, J. M. 1900. Additional notes and observations on the birds of northern Nebraska.

Proceedings of the Nebraska Ornithologists' Union 1: 15-18.

Benckeser, H. R. 1948. Notes from Brule. Nebraska Bird Review 16: 94-96.

Benckeser, H. R. 1956. Notes from Keith County. Nebraska Bird Review 24: 26.

Bendire, C. 1891. Directions for Collecting, Preparing, and Preserving Birds' Eggs and Nests. Part D of Bulletin of the United States National Museum, No. 39. Government Printing Office, Washington, District of Columbia. $10 \mathrm{pp}$.

Bennett, E. V. 1969. 1968 Nebraska nesting survey. Nebraska Bird Review 37: 39-46.

Bennett, E. V. 1973. 1972 Nesting nesting survey. Nebraska Bird Review 41: 3-9.

Bennett, E. V. 1975. 1974 Nebraska nesting survey. Nebraska Bird Review 43: 13-19.

Bennett, E. V. 1976. 1975 Nebraska nesting survey. Nebraska Bird Review 44: 8-11.

Bennett, E. V. 1980. 1978 Nebraska nesting survey. Nebraska Bird Review 48: 39-43.

Bennett, E. V. 1987. 1986 Nebraska nesting survey. Nebraska Bird Review 55: 30-35.

Bennett, W. W. 1937. Breeding of the Cinnamon Teal in Garden County, Nebraska. Nebraska Bird Review 5: 108-109.

Bent, A. C. 1953. Life Histories of North American Wood Warblers. Government Printing Office, Washington, District of Columbia. $734 \mathrm{pp}$.

Bent, A. C. 1929. Life Histories of North American Shore Birds, Pt.2. Government Printing Office, Washington, District of Columbia, $340 \mathrm{pp}$. 
Birkhead, T. 2016. The Most Perfect Thing. Bloomsbury Publishing, New York, New York. 288 pp.

Black, C. A. 1920. Bird records and glimpses of bird life in western Nebraska. Typed manuscript. Nebraska Ornithologists' Union Archives.

Bliese, J. C. W. 1975. A Monk Parakeet in the Kearney area. Nebraska Bird Review 43: 42.

Blinco, Mrs. G. 1946. Notes on Grosbeaks and Bohemian Waxwings at Chadron, Dawes County. Nebraska Bird Review 14: 45.

Blus, L. J. and J. A. Walker. 1966. Progress report on prairie grouse nesting study in the Nebraska Sandhills. Nebraska Bird Review 34: 23-30.

Bock, C. E. and W. C. Scharf. 1994. A nesting population of Cassin's Sparrows in the Sandhills of Nebraska. Journal of Field Ornithology 65: 472-475.

Bookhout, T. A. 1995. Yellow Rail (Coturnicops noveboracensis). In The Birds of North America, No. 139 (A. Poole and F. Gill, eds.). The Academy of Natural Sciences, Philadelphia, Pennsylvania and The American Ornithologists' Union, Washington, District of Columbia.

Bray, T. 1985. McCown's Longspur nest in Sioux County. Nebraska Bird Review 53: 81.

Bray, T. E., B. K. Padelford, and W. R. Silcock. 1986. The Birds of Nebraska: A Critically Evaluated List. Published by the authors. Omaha, Nebraska. 111 pp.

Brooking, A. M. 1944. Nesting of the White-necked Raven in Kearney County. Nebraska Bird Review 12: 40.

Brown, E. 1947. Nesting of the White-necked Raven in Kearney County. Nebraska Bird Review 15: 49.

Brown, M. B., S. J. Dinsmore, and C. R. Brown. 2012. Birds of Southwestern Nebraska. Institute of Agriculture and Natural Resources, University of Nebraska, Lincoln, Nebraska. 152 pp.

Bruner, L. Undated. Bruner Archive, Love Library, University of Nebraska, Lincoln, Nebraska.

Bruner, L. 1896. Some notes on Nebraska birds. In: Annual report of the Nebraska State Horticultural Society. 297 pp.

Bruner, L. 1901. Birds that nest in Nebraska. Proceedings of the Nebraska Ornithologists' Union 2: 48-61.

Bruner, L. 1902. A comparison of the bird-life found in the sand-hill region of Holt County in 1883-84 and in 1901. Proceedings of the Nebraska Ornithologists' Union 3: 59-63.

Bruner, L., R. W. Wolcott, and M. H. Swenk. 1904. A Preliminary Review of the Birds of Nebraska. Klopp and Bartlett Co., Omaha, Nebraska. 125 pp.

Busby, W. H. and J. L. Zimmerman. 2001. Kansas Breeding Bird Atlas. University Press of Kansas, Lawrence, Kansas. 466 pp.

Gabrielson, I. N. 1914. Ten day's bird study in a Nebraska swamp. Wilson Bulletin 21: 51-68.

Callaway, A. and S. Callaway. 1939. The Yellow-throated Vireo nesting at Fairbury, Jefferson County. Nebraska Bird Review 7: 29.

Callaway, S. and A. Callaway. 1940. Some unusual mid-summer birds noted in the Fairbury, Jefferson County, vicinity. Nebraska Bird Review 8: 94-95.

Carleton, J. H. 1983. The Prairie Logbooks: Dragoon campaigns to the Pawnee villages in 1844, and to the Rocky Mountains in 1845. University of Nebraska Press, Lincoln, Nebraska. $295 \mathrm{pp}$. 
Carriker, M. A. Jr. 1900. Nesting habits of the Raptores of Otoe County. Proceeding of the Nebraska Ornithologists' Union 1: 29-34.

Carriker, M. A. Jr. 1901. Mlscellaneous notes. Proceedings of the Nebraska Ornithologists' Union 2: 96-97.

Carriker, M. A. Jr. 1902. Notes on the nesting of some Sioux County Birds. Proceedings of the Nebraska Ornithologists' Union, No. 3: 75-89.

Cary, M. 1902. Some general remarks upon the distribution of life in northwest Nebraska. Proceedings of the Nebraska Ornithologists' Union 3: 63-75.

Cavitt, J. F. and C. A. Haas. 2000. Brown Thrasher (Toxostoma rufum). In The Birds of North America, No. 557 (A. Poole and F. Gill, eds.). The Birds of North America, Inc., Philadelphia, Pennsylvania.

Chase, W. 1956. Notes. Nebraska Bird Review 24: 11.

Chesser, R. T., K. J. Burns, C. Cicero, J. L. Dunn, A. W. Kratter, I. J. Lovette, P. C. Rassmussen, J. V. Remsen Jr., D. F. Stotz, and K. Winker. 2019. Sixtieth Supplement to the American Ornithological Society's Checklist of North American Birds. Auk XX: 1 - 23.

Childs, J. L. 1908. A trip to the Dismal River, Nebraska. Warbler 6: 9-13.

Cink, C. L. 1971. Some interesting summer bird records for Lancaster County in 1970. Nebraska Bird Review 39: 58-59.

Cink, C. L. 1972. A Great Blue Heron colony in Hitchcock County. Nebraska Bird Review 40: 7.

Cink, C. L. 1973. Summer records of the Short-billed Marsh Wren in Nebraska. Nebraska Bird Review 41: 17-19.

Cink, C. L. 1975. The Song Sparrow as a Nebraska Breeding Bird. Nebraska Bird Review 43: 3-8.

Cink, C. L. 1977. White-necked Raven. Nebraska Bird Review 45: 16.

Clausen, M. K. 1990. Mountain Plover sighted in Kimball County. Nebraska Bird Review 58: 98-99.

Coleman, G. A. Undated mss. Birds of Southeastern Nebraska. University of Nebraska Library, \#598.29782 QC6776. Lincoln, Nebraska. 32 pp.

Collister, Mrs. C. N. 1948. Nesting of the Double-crested Cormorant in Nebraska. Nebraska Bird Review 16: 22-26.

Collister, Mrs. C. N. 1950. Nesting birds on a Keith County farm. Nebraska Bird Review 18: 1-4.

Cooke, W. W. 1888. Report on Bird Migration in the Mississippi Valley in the years 1884 and 1885. Government Printing Office, Washington, District of Columbia. 313 pp.

Cooke, W. W. 1910. Distribution and Migration of North American Shorebirds. Government Printing Office, Washington, District of Columbia. 100 pp.

Coons, V. 1976. 1976. White-necked Raven reported. Nebraska Bird Review 44: 38.

Coons, V. 1983. House Finch nest at Grand Island. Nebraska Bird Review 51: 96.

Cortelyou, R. G. 1960. Letter to the editor. Nebraska Bird Review 28: 55.

Cortelyou, R. G. 1975. A Brown Creeper's nest in Nebraska. Nebraska Bird Review 43: 80-83.

Coues, E. 1872. Key to North American Birds. Naturalists' Agency, Salem, Massachusetts. 361 pp.

Coues, E. 1874. Field Ornithology and Checklist of North American Birds. Naturalists' Agency, Salem, Massachusetts. 116 pp, + 137 PP. 
Coues, E. 1903. Key to North American Birds, 5th edition. Dana Estes \& Co., Boston, Massachusetts. $1152 \mathrm{pp}$.

Crawford, J. C., Jr. 1901. Results of a collecting trip to Sioux County. Proceedings of the Nebraska Ornithologists' Union 2: 76-79.

Curd, R. C. 1999. A Brief History of the Boundaries of Nebraska and Indian - Surveyor Stories. The Boundaries Publishing Co., Chadron, Nebraska. 231 pp.

Cutright, N. J., B. R. Harriman, and R. W. Howe, Editors. 2006. Atlas of the Breeding Birds of Wisconsin. Wisconsin Society for Ornithology, Inc. Waukesha, Wisconsin. 264 pp.

Davis, W. E. Jr., and B. K. Butler. 2016. The American Ornithologists' Union: The First Century, 1883-1983. Nuttall Ornithological Club. Cambridge, Massachusetts. 405 pp.

Di Silvestro, Roger. 1975. Monk Parakeet. Nebraska Bird Review 43: 60.

Dinsmore, S. J. and W. R. Silcock. 1995. First nesting records for Mississippi Kite in Nebraska. Nebraska Bird Review 63: 88-89.

Ducey, J. E. 1980. Immature Yellow-crown Night Herons. Nebraska Bird Review 48: 87-88.

Ducey, J. E. 1988. Nebraska Birds: Breeding Status and Distribution. Simmons-Boardman Books. Omaha, Nebraska. $148 \mathrm{pp}$.

Dugger, B. D., K. M. Dugger, and H. L. Fredrickson. 1994. Hooded Merganser (Lophodytes cucullatus). In The Birds of North America, No. 98 (A. Poole and F. Gill, Eds.). Philadelphia, Pennsylvania: The Academy of Natural Sciences; Washington, District of Columbia: The American Ornithologists' Union.

Dunn, J. L. and K. L. Garrett. 1997. A Field Guide to the Warblers of North America. The Peterson Field Guide Series, Houghton Mifflin Co., New York, New York. 656 pp.

Eddleman, W. R., R. E. Flores, and M. L. Legare. 1994. Black Rail (Laterallus jamaicensis). In The Birds of North America, No. 123 (A. Poole and F. Gill, Eds.). Philadelphia, Pennsylvania: The Academy of Natural Sciences; Washington, District of Columbia.: The American Ornithologists' Union.

Editor. 1933. Here and there with the N. O. U. members. Nebraska Bird Review 1: 79-87.

Editor. 1938. Report on the thirty-sixth annual field day of the Nebraska Ornithologists' Union. Nebraska Bird Review 6: 47-48.

Editor. 1956a. Excerpts from letters to the editor. Nebraska Bird Review 24: 28-29.

Editor. 1956b. Reports of nests, nestlings and fledglings 1955. Nebraska Bird Review 24: 51-52.

Editor. 1971. Crested Tinamou. Nebraska Bird Review 39: 38-39.

Editor. 1972. 1972 (Forty-seventh) Spring migration and occurrence report. Nebraska Bird Review 40: 72-87.

Editor. 1973. 1972 (Fifteenth) Fall occurrence report. Nebraska Bird Review 41: 28-41.

Editor. 1974a. American Woodcock Nest. Nebraska Bird Review 42: 43.

Editor. 1974b. Cassin's Sparrow nesting in Nebraska. Nebraska Bird Review 42: 56-57.

Editor. 1976. Untitled addendum to "White-necked Raven reported." Nebraska Bird Review 44:

39.

Editor. 1977a. Great-tailed Grackles nesting in Nebraska. Nebraska Bird Review 45: 18.

Editor. 1977b. Poor-wills in Lancaster and Lincoln counties. Nebraska Bird Review 45: 42-43.

Editor. 1986. 1986 (Sixty-first) Spring occurrence report. Nebraska Bird Review 54: 46-64.

Editor. 1990. Fall occurrence report: update. Nebraska Bird Review 59: 45-48. 
Editor. 1991. Bald Eagle hatchling. Nebraska Bird Review 59: 50-51.

Editor. 1992. Bald Eagles hatched in Nebraska. Nebraska Bird Review 60: 59.

Ehrlich, P. R., D. S. Dobkin and D. Wheye. 1988. The Birder's Handbook. Simon and Schuster, New York, New York. 785 pp.

Eiche, A. 1901. Breeding of the Snowy Egret and Swallow-tailed Kite. Proceedings of the Nebraska Ornithologists' Union 2: 96.

Eigsti, W. E. 1947. "Drumming" in the Chimney Swift. Nebraska Bird Review 15: 9-11. Einemann, L. L. 1980. Gray (Hungarian) Partridge nest. Nebraska Bird Review 48: 88.

Ellison, W. G. (Editor). 2011. 2nd Atlas of the Breeding Birds of Maryland and the District of Columbia. Johns Hopkins University Press, Baltimore, Maryland. 494 pp.

Faulkner, D. 2010. Birds of Wyoming. Roberts and Co., Greenwood Village, Colorado. 404 pp.

Farrar, J. 2002. Watching trumpeters. Nebraskaland 80: 10-17.

Fiala, K. L. 1973. Prairie Falcons. Nebraska Bird Review 41: 19.

Fickel, T. 1979. Townsend's Solitaires in Sioux County. Nebraska Bird Review 47: 68-69.

Ford, N. L. 1959. Notes on the summer birds of western Nebraska. Nebraska Bird Review 27: 6-12.

Forsberg, M. 1995. Angels of the hills. Nebraskaland 73: 20-31.

Forsberg, M. 1997. Omaha's urban Peregines. Nebraskaland 75: 38-47.

Furnas, R. W. 1902. The Carolina Paroquet. Proceedings of the Nebraska Ornithologists' Union 3: 107.

Gabrielson, I. N. 1914. Ten days' bird study in a Nebraska swamp. Wilson Bulletin 26: 51-68.

Gates, D. Undated. Letter to F. W. Haecker (editor), Nebraska Bird Review. Nebraska Ornithologists' Union Archives.

Gates, D. 1959. Thirty-fifth annual cooperative spring migration and occurrence report. Nebraska Bird Review 27: 50-67.

Gates, D. and L. Gates. 1953. Nesting notes from Peru. Nebraska Bird Review 21: 23.

Gates, L. M. Undated. Scotts Bluff County Birds, 1915. UNSM archives.

Genoways, H. H., J. D. Hoffman, P. W. Freeman, K. Geluso, R. A. Benedict, and J. J. Huebschman. 2008. Mammals of Nebraska: Checklist, Key, and Bibliography. Bulletin of the University of Nebraska State Museum, Lincoln, Nebraska. 92 pp.

Glandon, E. W. 1939. Nesting of the Eastern Phoebe in Logan County. Nebraska Bird Review 7: 31.

Glandon, E. W. 1945. Nesting of the Scissor-tailed Flycatcher in Logan County. Nebraska Bird Review 13: 50-51.

Goss, N. H. 1891. History of the birds of Kansas. G. W. Crane and Co., Topeka, Kansas. 692 pp.

Green, R. C. 1978. Yellow-bellied Flycatcher. Nebraska Bird Review 46: 86.

Green, R. C. 1985. Northern Waterthrush. Nebraska Bird Review 53: 43.

Grier, B. 2009. Cordilleran flycatchers. Nebraskaland 87: 32-35).

Grzybowski, J. A. 1989a. Southern Great Plains Region, Spring 1989. American Birds 43: 500-501.

Grzybowski, J. A. 1989b. Southern Great Plains Region, Summer 1989. American Birds 43: 1334-1336. 
Grzybowski, J. A. 1995. Southern Great Plains Region, Summer 1995. American Birds 49: 945-948.

Grzybowski, J. A. 1996. Southern Great Plains Region, Summer 1996. American Birds 50: 965-968.

Haecker, F. W., R. A. Moser and J. B. Swenk. 1945. Checklist of the Birds of Nebraska. Nebraska Bird Review 13: 1-40.

Halbert, D. 1940. Notes on Nebraska reared Chukar Partridges and Valley California Quail. Nebraska Bird Review 8: 87-88.

Hall, Mrs. J. W. 1926. Report submitted to M. H. Swenk. Letter of Information 18: 2.

Hatch, D. E. and P. A. Garrels. 1971. Turkey Vulture nesting records for Nebraska - a new record for Sheridan County. Nebraska Bird Review 39: 18-20.

Heineman, Mrs. L. D. 1944. Nesting of the Piping Plover and Least Tern in Cass County. Nebraska Bird Review 12: 9-10.

Helsinger, M. J. 1985a. Black-necked Stilts nesting in Nebraska. Nebraska Bird Review 53: 72.

Helsinger, M. J. 1985b. Cinnamon Teal nest at Crescent Lake NWR. Nebraska Bird Review 53: 80.

Helsinger, M. J. 1985c. Common Snipe. Nebraska Bird Review 53: 80.

Herkert, J. R., D. E. Kroodsma, and J. P. Gibbs. 2001. Sedge Wren, (Cistothorus platensis). In: The Birds of North America, No. 582 (A. Poole and F. Gill, eds.). The Birds of North America, Inc., Philadelphia, Pennsylvania.

Hoge, G. L. 1964. Poor-wills near Powell. Nebraska Bird Review 32: 14.

Hopps, E. C. 2011. A late-season breeding record for the Summer Tanager in Nebraska. Nebraska Bird Review 79: 33-36.

Hudson, G. 1937. The Summer Tanager and other summering birds at Rock Bluff, Cass County. Nebraska Bird Review 5: 8-9.

Hudson, G. 1939. Some ornithological results of a six-weeks' collecting trip along the boundaries of Nebraska. Nebraska Bird Review 7: 4-7.

Jacobs, B. and J. D. Wilson. 1997. Missouri Breeding Bird Atlas. Natural History Series, No. 6. Missouri Department of Conservation, Jefferson City, Missouri. 430 pp.

James. E. 1972. Account of an Expedition from Pittsburgh to the Rocky Mountains. Imprint Society. Barre, Massachusetts. 547 pp.

James, J. D. and J. E. Thompson. 2001. Black-bellied Whistling-Duck (Dendrocygna autumnalis). In: Poole, A. and F. Gill (editors), The Birds of North America, No. 578. The Birds of North America, Inc., Philadelphia, Pennsylvania.

Jobanek, G. A. 1999. Narrative of a journey across the Rocky Mountains to the Columbia River, and a Visit to the Sandwich Islands, Chili, \&c., with a scientific appendix. Oregon State University Press, Corvallis, Oregon. 290 pp.

Johnston, Mrs. H. C. 1928. Report submitted to M. H. Swenk. Letter of Information 32: 9-10. Johnston, Mrs. H. C. 1934. The Eastern Carolina Wren nests again at Superior in 1934. Nebraska Bird Review 2: 62.

Jorgensen, J. G. and W. R. Silcock. 2015. First nesting record and status review of the Glossy Ibis in Nebraska. Nebraska Bird Review 83: 139-149. 
Jorgensen, J. G., S. K. Wilson, J. J. Dinan, S. E. Rehme, S. E. Steckler, and M. J. Panella. 2010. A review of modern Bald Eagle (Haliaeetus leucocephalus) nesting records and breeding status in Nebraska. Nebraska Bird Review 78: 121-126.

Kaul, R. B., D. M. Sutherland, and S. B. Rolfsmeier. 2011. The Flora of Nebraska, 2nd edition. University of Nebraska, Lincoln, Nebraska. 967 pp.

Keller, F. J. 1931a. Report submitted to M. H. Swenk. Letter of Information 61: 4.

Keller, F. J. 1931b. Report submitted to M. H. Swenk. Letter of Information 62: 1.

Kiff, L. F. 2005. History, present status, and future prospects of avian eggshell collections in North America. Auk 122: 994-999.

Kim, D. H. 2005. First Nebraska nest record for Henslow's Sparrow. The Prairie Naturalist 37: 171-173.

Kline, H. A. 1883a. Notes from Nebraska. Ornithologist and Oologist 8: 18-19.

Kline, H. A. 1883b. Short-eared Owl. Ornithologist and Oologist 8: 60-61.

Lemburg, W. W. 1976. White-necked Raven reported. Nebraska Bird Review 44: 38.

Lemburg, W. W. 2012. Report of a nesting Sora (Porzana carolina). Nebraska Bird Review 80: 40-42.

Lewis, H. F. 1931. Additional information concerning the Double-crested Cormorant, Phalacrocorax auritus auritus (Lesson). Auk 48: 207-214.

Lingle, G. R. 1983. A new nesting species for Nebraska. Nebraska Bird Review 51: 86-87.

Lock, R. A. 1975. Young Mountain Plover seen in Kimball County. Nebraska Bird Review 43: 54-56.

Lock, R. A. and R. Craig. 1975. Merlin nest in Nebraska. Nebraska Bird Review 43: 78-79.

Lock, R. A. and J. Schuckman. 1973. A Bald Eagle nest in Nebraska. Nebraska Bird Review 41: 76-77.

Ludlow, C. S. 1930. Report submitted to M. H. Swenk. Letter of Information 53: 2.

Lueshen, W. 1956. Say's Phoebe nesting in Nance Co. Nebraska Bird Review 24: 47-48.

Manning, R. 1981. Red-breasted Nuthatch nest. Nebraska Bird Review 49: 11.

Martell, M. and L. A. Pfannmuller. 2018. Minnesota Breeding Bird Atlas. Available at: https//mnbirdatlas.org. Accessed 22 Feb. 2018.

Mathisen, J. and A. Mathisen. 1960. History and status of introduced game birds in Nebraska. Nebraska Bird Review 28: 19-22.

Mickel, C. E. and R. W. Dawson. 1916. Scotts Bluff County bird notes, 1916. Nebraska Ornithologists' Union Archives.

Mohler, L. L. 1952. Wilson's Phalarope nests in Sheridan and Box Butte counties. Nebraska Bird Review 20: 45.

Mollhoff, W. J. 1997a. A probable nesting of Clark's Nutcracker (Nucifraga columbiana) in Nebraska. Nebraska Bird Review 65: 147-150.

Mollhoff, W. J. 1997b. Notes on the nesting biology of Pygmy Nuthatches in Nebraska. Nebraska Bird Review 65: 150-159.

Mollhoff, W. J. 2000a. Review of the breeding status of Lewis's Woodpecker in Nebraska. Nebraska Bird Review 68: 50-55.

Mollhoff, W. J. 2000b. Review of the breeding status of Pinyon Jay in Nebraska. Nebraska Bird Review 68: 126-130. 
Mollhoff, W. J. 2001a. The Nebraska Breeding Bird Atlas, 1984-1989. Nebraska Ornithologists' Union, Occasional Papers No. 7 / Nebraska Game and Parks Commission, Technical Series No. 20. Lincoln, Nebraska. 233 pp.

Mollhoff, W. J. 2001b. 1999 - 2000 Nebraska Nesting Report. Nebraska Bird Review 69: 92-101. Mollhoff, W. J. 2004a. The 2001 Nebraska Nesting Report. Nebraska Bird Review 72: 99-103. Mollhoff, W. J. 2004b. The 2002 Nebraska nest report. Nebraska Bird Review 72: 153-158. Mollhoff, W. J. 2005a. The 2003 - 2004 Nebraska nest report. Nebraska Bird Review 73: 15-19. Mollhoff, W. J. 2005b. The 2005 Nebraska nest report. Nebraska Bird Review 73: 119-123. Mollhoff, W. J. 2006. The 2006 Nebraska nest report. Nebraska Bird Review 74: 142-147. Mollhoff, W. J. 2008. The 2007 Nebraska nest report. Nebraska Bird Review 76: 155-165. Mollhoff, W. J. 2016. The Second Nebraska Breeding Bird Altas, 2006-2011. Bulletin of the University of Nebraska State Museum. Vol. 29. University of Nebraska State Museum, Lincoln, Nebraska. 304 pp.

Mollhoff, W. J. 2018. The Northern Saw-Whet Owl (Aegolius acadicus) Nest Box Project : The First Seven Years. Nebraska Bird Review 86: 168-174.

Mollhoff, W. J., J. Gubanyi, and M. A. Brogie. 2008. First report of Ash-throated Flycatcher (Myiarchus cinerascens) breeding in the Nebraska Panhandle region. Nebraska Bird Review 76: 32-37.

Moser, R. A. 1940. The Piping Plover and Least Tern nesting in Omaha. Nebraska Bird Review 8: 92-94.

Mossman, M. J. and M. A. Brogie. 1983. Breeding status of selected bird species in the Niobrara Valley Preserve area, Nebraska. Nebraska Bird Review 51: 52-62.

Nebraska Game and Parks Commission archives. Nebraska Game and Parks Commission. Lincoln, Nebraska.

Newell, W. 1950. Notes on the nesting activities of the Marsh Hawk. Nebraska Bird Review 18: 16-17.

Nolan, V., Jr., E. D. Ketterson, and C. A. Buerkle. 1999. Prairie Warbler (Dendroica discolor). In The Birds of North America, No. 455 (A. Poole and F. Gill, eds.). The Birds of North America, Inc., Philadelphia, Pennsylvania.

Oberholser, H. C. and W. L. McAtee. 1920. Waterfowl and their Food Plants in the Sandhill Region of Nebraska. Government Printing Office, Washington, District of Columbia. 77 pp.

Olson, Mrs. 1956. Reports of nests, nestlings, and fledglings. Nebraska Bird Review 24: 14.

Orr, W. J. and J. C. Porter. 1983. A journey through the Nebraska region in 1833 and 1834: From the diaries of Prince Maximilian of Wied. Nebraska History 64: 325-453.

Padelford, B. and L. Padelford. 1973. Monk Parakeets in Omaha. Nebraska Bird Review 41: 15-17.

Padelford, B. and L. Padelford. 1980. Summer Tanager nest. Nebraska Bird Review 48: 90.

Palmer, R. S. 1962. Handbook of North American Birds, Vol. 1. Yale University Press, New Haven, Connecticut. $567 \mathrm{pp}$.

Palmer, R. S. 1976. Handbook of North American Birds, Vol. 3. Yale University Press, New Haven, Connecticut. 560 pp.

Patton, Mrs. F. J. 1953. Wood Duck nests in Wymore. Nebraska Bird Review 21: 38. 
Pearse, A. S. 1896. Notes on some birds of Gage Co., Neb. The Oologist 13: 15-16.

Pickwell, G. 1925. Some nesting habits of the Belted Piping Plover. Auk 42: 326-332.

Rapp, W. F. Jr., J. L. C. Rapp, H. E. Baumgarten, and R. A. Moser. 1958. Revised Checklist of Nebraska Birds. Occasional Papers of the Nebraska Ornithologists' Union, No. 5. Crete, Nebraska. 45 pp.

Rapp, W. F. Jr., J. L. C. Rapp, H. E. Baumgarten, R. A. Moser (with Supplement through 1970 by R. G. Cortelyou and K. E. Fiala). 1971. Revised Checklist of Nebraska Birds. Occasional Papers of the Nebraska Ornithologists' Union, No. 5A. 48 pp.

Ridgway, R. 1887. A Manual of North American Birds. J. B. Lippincott Co., Philadelphia, Pennsylvania. 631 pp. +124 plates.

Ridgway, R. 1900. A Manual of North American Birds. 4th edition. J.B. Lippincott Co., Philadelphia, Pennsylvania. 653 pp. +124 plates.

Ridgway, R. 1902. The Birds of North and Middle America. Smithsonian Institution, United States National Museum, Bulletin No. 50, Part 2. Government Printing Office, Washington, District of Columbia. $832 \mathrm{pp}$.

Robbins, M. B. 2018. The status and distribution of birds in Missouri. University of Kansas Biodiversity Institute. Lawrence, Kansas. $332 \mathrm{pp}$.

Rosche, R. C. 1974. A Nebraska Swainson's Thrush nest. Nebraska Bird Review 42:17.

Rosche, R. C. 1982. The Birds of Northwestern Nebraska and Southwestern South Dakota. Published by the author. Chadron, Nebraska. 100 pp.

Rowe, N. 1938. The Northern Pine Siskin nesting in Adams County. Nebraska Bird Review 6: 29. Sather, J. H. Undated. Muskrat field notes, June 1949-June 1953. Unpublished mss.

Schock, A. J. 1983. Pine Siskin nests at Wayne State College. Nebraska Bird Review 51: 89.

Seabury, Mrs. G. 1953. Nesting of Crested Flycatcher in Antelope County. Nebraska Bird Review 21: 26.

Seabury, Mrs. L. 1956. Reports of nests, nestlings and fledglings. Nebraska Bird Review 24: 14. Sharp, W. M. 1939. Notes on certain ducks nesting in Nebraska. Nebraska Bird Review 7: 1-4.

Sharpe, R. S. 1964. Yellow-crowned Night-Heron nesting in Nebraska. Nebraska Bird Review 32: 9-11.

Sharpe, R. S. 1970. Swamp Sparrow breeding on the Middle Loup River. Nebraska Bird Review 38: $18-19$.

Sharpe, R. S. 1967. The 1966 nesting season. Nebraska Bird Review 35: 29-38.

Sharpe, R. S. and R. R. Payne. 1966. Nesting birds of the Crescent Lake National Wildlife Refuge. Nebraska Bird Review 34: 31-34.

Sharpe, R. S., W. R. Silcock, and J. G. Jorgensen. 2001. The Birds of Nebraska: Their Distribution and Temporal Occurrence. University of Nebraska Press, Lincoln, Nebraska. 520 pp.

Shoemaker, F. H. Undated. Shoemaker Archive. Love Library, University of Nebraska, Lincoln.

Shoemaker, F. H. 1901. Nest of the Ruby-throated Hummingbird. Proceedings of the Nebraska Ornithologists' Union 2: 34-38.

Short, L. L. 1966. Some spring migrant and breeding records from northern Nebraska. Nebraska Bird Review 34: 18-20.

Sibley, C. G. 1960. The electrophoretic patters of avian egg-white proteins as taxonomic characters. Ibis 102: 215-284. 
Sibley, C. G. 1962. The comparative morphology of proteins as data for classification. Systematic Zoology 11: 108-118.

Silcock, W. R. 1995. Fall field report, August - November 1995. Nebraska Bird Review 63: 94-114.

Silcock, W. R. 1999a. Summer field report, June to July, 1999. Nebraska Bird Review 67: 86-103.

Silcock, W. R. 1999b. Fall field report, August to November, 1999. Nebraska Bird Review 67: 118-139.

Silcock, W. R. 2000a. Spring field report, March to May 2000. Nebraska Bird Review 68: 55-81.

Silcock, W. R. 2000b. Summer field report, June and July 2000. Nebraska Bird Review 68: 106-126.

Silcock, W. R. 2001. Summer field report, June and July 2001. Nebraska Bird Review 69: 106-132.

Silcock, W. R. 2002. Summer field report, June - July 2002. Nebraska Bird Review 70: 94-119. Silcock, W. R. 2003a. Summer field report, June - July 2003. Nebraska Bird Review 71: 106-127. Silcock, W. R. 2003b. Fall field report, August - November 2003. Nebraska Bird Review 71: 146-166.

Silcock, W. R. 2004. Spring field report, March - May 2004. Nebraska Bird Review 72: 38-58. Silcock, W. R. 2005a. Spring field report, March - May 2005. Nebraska Bird Review 73: 46-47. Silcock, W. R. 2005b. Summer field report, June - July 2005. Nebraska Bird Review 73: 94-113. Silcock, W. R. 2006. Summer field report, June - July 2006. Nebraska Bird Review 74: 78-95. Silcock, W. R. 2007. Spring field report, March - May 2007. Nebraska Bird Review 75: 34-52. Silcock, W. R. 2008a. Spring field report, March - May 2008. Nebraska Bird Review 76: 51-71. Silcock, W. R. 2008b. Summer field report, June - July 2008. Nebraska Bird Review 76: 94-111. Silcock, W. R. 2009a. Spring field report, March - May 2009. Nebraska Bird Review 77: 46-68. Silcock, W. R. 2009b. Summer field report, June - July 2009. Nebraska Bird Review 77: 94-110. Silcock, W. R. 2010. Summer field report, June - July 2010. Nebraska Bird Review 78: 86-102. Silcock, W. R. 2012a. Spring field report, March - May 2012. Nebraska Bird Review 80: 46-71. Silcock, W. R. 2012b. Summer field report, June - July 2012. Nebraska Bird Review 80: 86-103. Silcock, W. R. 2014a. Summer field report, June - July 2014. Nebraska Bird Review 82: 98-121. Silcock, W. R. 2014b. Fall field report, August - November 2014. Nebraska Bird Review 82: 150-181.

Silcock, W. R. 2015a. Spring field report, March - May 2015. Nebraska Bird Review 83: 54-85. Silcock, W. R. 2015b. Summer field report, June - July 2015. Nebraska Bird Review 83: 102-124. Silcock, W. R. 2016. Summer field report, June - July 2016. Nebraska Bird Review 84: 110-131. Silcock, W. R. 2017. Summer field report, June - July 2017. Nebraska Bird Review: 85: 94-120. Silcock, W. R. and J. G. Jorgensen. 1996. Fall field report, August - November 1996. Nebraska Bird Review 64: 106-129.

Silcock, W. R. and J. G. Jorgensen. 1997. Spring field report, March - May 1997. Nebraska Bird Review 65: 74-99.

Silcock, W. R. and J. G. Jorgensen. 1998. Spring field report, March to May 1998. Nebraska Bird Review 66: 30-55. 
Silcock, W. R. and J. G. Jorgensen. 1999. Spring field report, March to May 1999. Nebraska Bird Review 67: 42-71.

Silcock, W. R. and J. G. Jorgensen. 2007. Henslow's Sparrow status in Nebraska. Nebraska Bird Review 75: 13-16.

Silcock, W. R. and J. G. Jorgensen. 2018. Birds of Nebraska Online. Available at: https://birds.outdoorsnebraska.gov. Accessed 4 April 2018.

Silcock, W. R. and R. C. Rosche. 1994a. Spring field report, March - May, 1994. Nebraska Bird Review 62: 66-88.

Silcock, W. R. and R. C. Rosche. 1994b. Fall field report, August - November 1994. Nebraska Bird Review 62: 126-149.

Smith, W. C. 1913. A list of Nebraska birds observed and collected by Wm. C. Smith, Long Pine, Nebr. Submitted to M. H. Swenk on 3 October 1913. Nebraska Ornithologists' Union Archives.

Snyder, L. and B. L. Bly. 2009. Differential use of agricultural fields and rangeland nesting habitat by McCown's Longspur (Calcarius mccownii) and Chestnut-sided Longspur(Calcarius ornatus) in western Nebraska. Nebraska Bird Review 77: 35-41.

Spreyer, M. F. and E. H. Bucher. 1998. Monk Parakeet (Myiopsitta monachus). In The Birds of North America, No. 322 (A. Poole and F. Gill, eds.). The Birds of North America, Inc., Philadelphia, Pennsylvania.

Steenhof, K., M. N. Kochert, C. L. McIntyre, and J. L. Brown. 2017. Coming to terms about describing Golden Eagle reproduction. Journal of Raptor Research 51: 378-390.

Stephens, T. C. 1957. The birds of Dakota County, Nebraska. Revised and annotated by W. Youngworth. Nebraska Ornithologists' Union, Occasional Papers No. 3. 28pp.

Stewart, C. A. 1943 . Nesting of the Red-shouldered Hawk in Sarpy County. Nebraska Bird Review 11: 25-30.

Stipsky, J. E. 1930. A nesting summary submitted to M. H. Swenk. Letter of Information 46: 4.

Stipsky, J. E. 1934. Field notes submitted to M. H. Swenk. Nebraska Ornithologists' Union Archives.

Swenk, M. H. Undated. Correspondence with A. M. Brooking. Nebraska Ornithologists' Union Archives.

Swenk, M. H. 1887-1916. Department Correspondence. Nebraska Ornithologists' Union Archives.

Swenk, M. H. 1895-1915. Department correspondence. Nebraska Ornithologists' Union Archives.

Swenk, M. H. 1902a. Diary and Ornithological Journal. Expedition of Department of Entomology and Ornithology, University of Nebraska, June 12, 1902 to August 14, 1902. Nebraska Ornithologists' Union Archives. 46 pp.

Swenk, M. H. 1902b. Additional notes on Gage County birds. Proceedings of the Nebraska Ornithologists' Union 3: 107.

Swenk, M. H. 1906. Some Nebraska bird notes. Auk 23: 108-109.

Swenk, M. H. 1915. The birds and mammals of Nebraska. In: The Nebraska Blue Book, 1915. State Journal Co., Lincoln, Nebraska. 989 pp. 
Swenk, M. H. 1918. Revisory notes on the list of the birds of Nebraska. Wilson Bulletin 25: 12-17.

Swenk, M. H. 1920. The birds and mammals of Nebraska. In: The Nebraska Blue Book, 1920. State Journal Co., Lincoln, Nebraska. 536 pp.

Swenk, M. H. 1921. Nesting of the Red Crossbill in Nebraska. Wilson Bulletin 28: 38-39.

Swenk, M. H. 1928. Letter of Information, No. 32: 1-10.

Swenk, M. H. 1929. The Pine Siskin in Nebraska: Its seasonal abundance and nesting. Wilson Bulletin 41: 77-92

Swenk, M. H. 1930. Letter of Information, No. 52: 1-4.

Swenk, M. H. 1931. Letter of Information, No. 61: 1-4.

Swenk, M. H. 1932. Letter of information, No. 66: 12-13.

Swenk, M. H. 1933. A brief synopsis of the birds of Nebraska. Nebraska Bird Review 1: 142-151.

Swenk, M. H. 1934. The Interior Carolina Paroquet as a Nebraska Bird. Nebraska Bird Review 2: 55-59.

Swenk, M. H. 1936. A study of the distribution, migration and hybridism of the Rose-breasted and Rocky Mountain Black-headed Grosbeaks in the Missouri Valley region. Nebraska Bird Review 4: 27-40.

Swenk, M. H. and R. W. Dawson. 1921. Notes on the distribution and migration of Nebraska birds. Wilson Bulletin 28:132-141.

Swenk, M. H. and E. Fichter. 1942. Distribution and migration of the Solitary Sandpiper in Nebraska. Nebraska Bird Review 10: 15-22.

Swenk, M. H. and L. M. Gates. Undated mss. The summer birds of Scottsbluff County. Nebraska Ornithologists' Union Archives.

Swenk, M. H. and J. T. Zimmer. 1912. Some notes on the summer birds of southwestern Nebraska. Proceedings of the Nebraska Ornithologists' Union 5: 39-50.

Tallman, D. A., D. L. Swanson, and J. S. Palmer. 2002. Birds of South Dakota. Midstate/Quality Quick Print, Aberdeen, South Dakota. $441 \mathrm{pp}$.

Taylor, W. E. 1888. A catalogue of Nebraska birds arranged according to the checklist of the American Ornithological Union. pp 111-118. In: Annual Report of the Nebraska State Board of Agriculture for 1887. State Journal Co., Lincoln, Nebraska. 392 pp.

Taylor, W. E. and A. H. Van Vleet. 1889. Notes on Nebraska Birds. Ornithologist and Oologist 14: $163-165$.

Thwaites, R. G. 1905. Early Western Travels. Vol. 15, Appendix A. Arthur H. Clark Co. Cleveland, Ohio. 356 pp.

Tomback, D. F. 1995. A possible breeding record for Clark's Nutcracker in northwestern Nebraska in 1987. Nebraska Bird Review 63: 114-115.

Tout, W. 1901. Nebraska Birds, 1895-1901. Unpublished manuscript. Nebraska Ornithologists' Union Archives.

Tout, W. 1902. Ten years without a gun. Proceedings of the Nebraska Ornithologists' Union 3: 42-45.

Tout, W. 1936. Breeding of the Common Rock Wren at North Platte, Lincoln County. Nebraska Bird Review 4: 54-55.

Tout, W. 1947. Lincoln County Birds. Published by the author. North Platte, Nebraska. 191 pp. 
Trostler, I. S. 1896. Notes by I. S. Trostler for Bruner's Birds of Nebraska. Nebraska Ornithologists' Union Archives.

Trostler, I. S. 1901. Notes regarding a Chimney Swift tree. Proceeding of the Nebraska Ornithologists' Union 2: 48.

Van Tyne, J. and A. J. Berger. 1959. Fundamentals of Ornithology. John Wiley \& Sons, Inc., New York, New York. 624 pp.

VertNet, an online museum database. Available at: http://www.portal.vertnet.org. Accessed 30 Dec. 2017.

Wallace, J. E. 1901. Notes from Omaha. Proceedings of the Nebraska Ornithologists' Union 2: 97.

Weakly, H. E. 1939. The Whooping Crane and other birds seen in Lincoln County in the spring of 1939. Nebraska Bird Review 7: 30.

Wensien, R. 1962. Nesting report, 1961. Nebraska Bird Review 30: 24-25.

White, C. A. 1893. The Raptores of Omaha and vicinity. Oologist 10: 138-140.

White, C. M., N. J. Clum, T. J. Cade, and W. G. Hunt. 2002. Peregrine Falcon (Falco peregrinus). In: Poole, A. and F. Gill (eds.). The Birds of North America, No. 660. The Birds of North America Inc., Philadelphia, Pennsylvania.

Wickersham, L. (Editor). 2016. The Second Colorado Breeding Bird Atlas. Colorado Bird Atlas Partnership, Denver, CO., and Colorado Parks and Wildlife, Denver, Colorado. 727 pp.

Williams, F. 1979. Southern Plains Region. American Birds 33: 876-877.

Wilson, B. L., J. and H. Minyard, and T. Bray. 1985. Hybrid bluebirds in the Pine Ridge. Nebraska Bird Review 53: 67.

Wilson, B. L. and J. and H. Minyard. 1986. Hybrid bluebird update. Nebraska Bird Review 54: 26-27.

Wilson, L. E. 1945. Nesting of the Cedar Waxwing in Washington County. Nebraska Bird Review 13: 50.

Wishart, D. J. (editor) 2004. Encyclopedia of the Great Plains. University of Nebraska Press, Lincoln, Nebraska. 919 pp.

Wolfe, C. W. 1965. A parasitized Prairie Chicken nest. Nebraska Bird Review 33: 68.

Woodruff, F. M. 1906. The Birds of the Chicago Area. Chicago Academy of Sciences. Bulletin 6 of the Natural History Survey. 221 pp.

Zimmer, J. T. Undated. Egg collection data cards. University of Nebraska State Museum Archives.

Zimmer, J. T. 1913. Birds of the Thomas County Forest Reserve. Proceedings of the Nebraska Ornithologists' Union 5: 51-104. 


\section{Abbreviations}

AOU: American Ornithologists' Union.

CAS: California Academy of Sciences, San Francisco, CA

CLNWR : Crescent Lake National Wildlife Refuge, Garden Co., NE

$\mathrm{cm}$ : centimeter

CM: Carnegie Museum, Pittsburgh, PA

CNRCP: Cornell Nest Record Card Program, Cornell University, Ithaca, NY

CRCM: C. R. Connor Museum, University of Washington, Pullman, WA

DMNS: Denver Museum of Nature and Science, Denver, CO

f: foot, feet

FMNH: Field Museum of Natural History, Chicago, IL

HM: Hastings Museum, Hastings, NE

HSU: Humboldt State University, Arcata, CA

ICSP: Indian Cave State Park, Nemaha and Richardson counties, NE

ISM: Illinois State University Museum, Springfield, IL

m: meter, meters

mi.: mile, miles

MICM: Mormon Island Crane Meadows, Alda, Hall County, NE (=PRWCMT, =WCT)

MCZ: Museum of Comparative Zoology, Harvard, Cambridge, MA

MSU: Michigan State University, East Lansing, MI

MVZ: Museum of Vertebrate Zoology, University of California, Berkeley, CA

NBBAP I / II: Nebraska Breeding Bird Atlas Projects

NVP: Niobrara Valley Preserve, The Nature Conservancy, Brown - Keya Paha Counties.

NBR: Nebraska Bird Review

NGPC: Nebraska Game and Parks Commission, Lincoln, NE

NNHP: Nebraska Natural Heritage Project, Nebraska Game and Parks Commission

NNLP: Nebraska Natural Legacy Project, Nebraska Game and Parks Commission

NOU: Nebraska Ornithologists' Union

NPNWR: North Platte National Wildlife Refuge, Scotts Bluff Co., NE

NRD: Natural Resource District

NYSM: New York State Museum, Albany, NY

OMNH: Sam Noble Oklahoma Museum of Natural History, Norman, OK

PRWCMT: Platte River Whooping Crane Maintenance Trust, Alda, NE (=MICM, =WCT)

PSM: James R. Slater Museum of Natural History, University of Washington, Tacoma, WA

ROM: Royal Ontario Museum, Toronto, Ontario, Canada

SBM: Sellors-Barton Museum, Ainsworth, NE

SBMNH: Santa Barbara Museum of Natural History, Santa Barbara, CA

SMNH: James R. Slater Museum of Natural History, University of Washington, Tacoma, WA

SRA: State Recreation Area

TNC: The Nature Conservancy

UFMNH: University of Florida Museum of Natural History, Gainsville, FL

UKBI: University of Kansas Biodiversity Institute, Lawrence, KS

UMMZ: University of Michigan, Ann Arbor, MI 
UNL: University of Nebraska, Lincoln, NE

UNSM: University of Nebraska State Museum, Lincoln, NE

USNMNH: United States National Museum of Natural History, Washington, DC

VNWR: Valentine National Wildlife Refuge, Cherry Co., NE

WCT: Whooping Crane Trust, Hall County, NE (=MICM, =PRWCMT)

WFVZ: Western Foundation of Vertebrate Zoology, Camarillo, CA

WHNC: Wildcat Hills Nature Center, Gering, NE

WMA: Wildlife Management Area

WPA: Waterfowl Production Area

YPM: Yale Peabody Museum, New Haven, CT. 


\section{GAZETTEER}

The following are locations I found noted on historic nest records which are not found on current maps.

Agate, Agate Springs Ranch, Sioux Co. Post Office 1899 - 1970. On Niobrara River south of Harrison on Hwy 29.

Albright, Douglas Co. Neighborhood now in South Omaha, near Sarpy County line west of Bellevue.

Badger, Holt Co. Post office 1890 - 1903, on the Niobrara River, 6 mi. SW of Butte.

Ballard's Marsh (WMA), Cherry Co. Extensive wetland complex $18 \mathrm{mi}$. S of Valentine.

Belmont, Dawes Co. Station on C.B. \& Q. Railroad 12 mi. SSE of Crawford.

Bouyer's Island, Douglas Co. Also "Booyer's Island." Probably does not refer to the area of the current Boyer's Chute, NWR, in Washington County.

Bruner Brothers Ranches, Holt Co. $\sim 5 \mathrm{mi}$. SW of Swan Lake near the head of the Cedar River. Lawrence Bruner and several family members made land claims there in 1883 . He stopped to visit in 1901 while returning from a collecting trip to the Pine Ridge and reported on the changes in the avifauna.

Carns, Keya Paha Co. Post office on Niobrara River, 1879 - 1943. NE of Bassett near Laughing Water Ck.

Child's Point, Sarpy Co. (also Childs Point, Child's Woods, Child's Timber, Bellevue Woods). Used in 19th and early 20th centuries to refer generally to what is now Fontenelle Forest and Gifford Point WMA.

Cody Lake, Cherry Co. Extensive hemi-marsh lake north of Cody, part if it lies in South Dakota.

Coffin Spring, Sarpy Co. Spring, and now a named trail, at Fontenelle Forest. Birders in the area, including Shoemaker, Van Sant, and Trostler, regularly took the train to Albright and hiked through the area while making photographs and collecting specimens.

Crystal Lake, Dakota Co. Oxbow lake on west side of South Sioux City.

Cutoff Lake (also Cut Off, or Cut-off), Douglas Co., now known as Carter Lake, IA.

Crescent Lake, Garden Co. Namesake of the later Crescent Lake National Wildlife Refuge.

Cushman Park, Lancaster Co. Now in western part of Lincoln Municipal Airport.

Dunlap, Dawes Co. Post Office, 1888 - 1935, 5 mi. E of Box Butte Reservoir, at US 385.

Florence Lake, Douglas Co. Ox-bow lake near Missouri River, N of the present Carter Lake.

Forest Reserve, Thomas Co. Later became the Nebraska National Forest, Bessey Division.

Fort Kearny, Kearney Co. Occupied 1848 - 1871. Named for General Stephen Kearny, a commander in the War of 1812, and the California Expedition during 1846 Mexican War. Currently a state park.

Fort Niobrara, Cherry Co. Army fort 1880 - 1906. Now Fort Niobrara National Wildlife Refuge.

Gerlach's Canyon, Sioux Co. Also Garlocke's Canyon. East Monroe Ck. canyon. Now part of Gilbert-Baker WMA.

Gifford Peninsula, Sarpy Co. Easternmost part of land bounded by the Missouri River. Also: Gifford's Woods, Gifford Point, Gifford Point WMA.

Glen, Sioux Co. Community on White River, $15 \mathrm{mi}$. SW of Crawford. 
Holly, Sheridan Co. Post office 1890 - 1904. Currently a church on Hwy 87, halfway between Rushville and South Dakota border.

Hudson Lake, Cherry Co. 13 mi. S, 8 mi. W of Valentine.

Jamaica, Lancaster Co. Union Pacific Railroad depot, 3 mi. NW of Roca.

Jim Creek, Sioux Co. Tributary of Warbonnet Creek in NW Sioux Co.

Moran Canyon, Lincoln Co. North-draining canyon, feeds into Platte River $\sim 6 \mathrm{mi}$. W of Maxwell.

North Platte Reservoir, Lincoln Co. Now Lake Maloney Reservoir State Recreation Area.

Papio Creek, Douglas Co. An early name for Papillion Creek.

Prairie Dog Badlands, Prairie Dog Ck., Sioux Co. On tributary to Warbonnet Creek in NW Sioux

Co.

Pries Lake, Douglas Co. Dammed-up former river channel near Florence.

Rock Bluff, Cass Co. Post office, 1857 - 1904, near Rock Ck. which was dammed to form Beaver Lake.

Rockland, Cass Co. Projected town, never built, just south of Rock Bluff.

Rockport, Washington Co. Short-lived Missouri River port near south border of Washington, Co.

Rocky Hollow, Kimball Co. A site with reliable springs in an arid area. $11 \mathrm{mi}$. N, $5 \mathrm{mi}$. E of Kimball.

Saltillo, Lancaster Co. Burlington Northern railroad station across Salt Creek east of Jamaica.

Shafer Lake, Garden Co. Now part of CLNWR.

Silver Lake, Dakota Co. A former marsh in old ox-bow, just west of South Sioux City.

Simeon, Cherry County. Post office 1885 - 1954, on Gordon Creek, 22 miles S of Crookston.

Sioux Lookout, Lincoln Co. Prominent escarpment above Platte River Valley, SW of Fort McPherson National Cemetery.

Sowbelly Canyon/Creek, Sioux Co. Originates NE of Harrison, flows N into Warbonnet Ck.

Spring Ranch, Clay Co. Former Pony Express Station and community on Oregon Trail, $7 \mathrm{mi}$. S of Glenville.

Squaw Creek Canyon, Sioux Co. A northern tributary of Warbonnet Creek.

State Farm, Lincoln Co. State agriculture experimental station on State Farm Rd., North Platte.

Steven Creek, Lancaster Co. Post Office 1868 - 1870, near 84th St. and Havelock Ave., Lincoln.

Swan Lake, Holt Co. Largest lake in SW Holt Co.

Sweetwater Lake, Cherry Co. Located on Valentine National Wildlife Refuge.

Trout Lake, Cherry County. 20 miles S of Valentine.

Warbonnet Creek/Canyon, Sioux Co. Originates in Pine Ridge near Wyoming border, flows NE to join Hat Creek SW of Montrose.

Woodland, Lancaster Co. Former community on Elk Creek, just N of NW corner of Lincoln Municipal Airport.

Woodlawn, Lancaster Co. Community 5 mi. S. of Raymond, on Highway 34. 